\title{
Importance of Dietary Phosphorus for Bone Metabolism and Healthy Aging
}

\author{
Juan Serna ${ }^{1}(\mathbb{D})$ and Clemens Bergwitz ${ }^{2, *(D)}$ \\ 1 Yale College, Yale University, New Haven, CT 06511, USA; juan.serna@yale.edu \\ 2 Section of Endocrinology and Metabolism, Department of Internal Medicine, Yale School of Medicine, \\ New Haven, CT 06519, USA \\ * Correspondence: clemens.bergwitz@yale.edu
}

Received: 20 August 2020; Accepted: 26 September 2020; Published: 30 September 2020

\begin{abstract}
Inorganic phosphate $\left(P_{i}\right)$ plays a critical function in many tissues of the body: for example, as part of the hydroxyapatite in the skeleton and as a substrate for ATP synthesis. $P_{i}$ is the main source of dietary phosphorus. Reduced bioavailability of $P_{i}$ or excessive losses in the urine causes rickets and osteomalacia. While critical for health in normal amounts, dietary phosphorus is plentiful in the Western diet and is often added to foods as a preservative. This abundance of phosphorus may reduce longevity due to metabolic changes and tissue calcifications. In this review, we examine how dietary phosphorus is absorbed in the gut, current knowledge about $P_{i}$ sensing, and endocrine regulation of $P_{i}$ levels. Moreover, we also examine the roles of $P_{i}$ in different tissues, the consequences of low and high dietary phosphorus in these tissues, and the implications for healthy aging.
\end{abstract}

Keywords: dietary phosphorus; inorganic phosphate $\left(\mathrm{P}_{\mathrm{i}}\right)$; hypophosphatemia; hyperphosphatemia; mineralization; absorption; paracellular; transcellular

\section{Introduction}

Phosphorus is one of the essential elements of the human body and is required for a diverse range of processes, such as ATP synthesis, signal transduction, and bone mineralization. The vast majority $(85 \%)$ of phosphorus in the body exists as a component of hydroxyapatite $\left[\mathrm{Ca}_{10}\left(\mathrm{PO}_{4}\right)_{6}(\mathrm{OH})_{2}\right]$ in the extracellular matrix of bone and teeth [1]. In contrast, intracellular phosphorus accounts for $14 \%$ of total body phosphorus, and only $1 \%$ is present, mostly as inorganic phosphate $\left(\mathrm{P}_{\mathrm{i}}\right)$, in extracellular fluids [1]. Phosphorus most commonly occurs as a salt of phosphoric acid, which is an essential physiological buffer referred to as $P_{i}$. Although we will focus on this form of phosphorus, it is important to note that phosphorus is also a component of phospholipids, DNA, RNA, ATP, and creatine phosphate (CrP). At physiological $\mathrm{pH}, \mathrm{P}_{\mathrm{i}}$ is apportioned $4: 1$ between its divalent form, $\mathrm{HPO}_{4}{ }^{2-}$, and its monovalent form, $\mathrm{H}_{2} \mathrm{PO}_{4}{ }^{-}$, respectively [2]. Moreover, $\mathrm{P}_{\mathrm{i}}$ also forms dimers (such as pyrophosphate) and polymers (such as polyphosphate) [3-5]. Alternatively, $\mathrm{P}_{\mathrm{i}}$ may be covalently bound in organic molecules, including inositol pyrophosphates, membrane phospholipids, phosphoproteins, and ribonucleic acids [3-5].

As a result of its importance in health, the maintenance of extracellular $\mathrm{P}_{\mathrm{i}}$ homeostasis is imperative. Chronic $\mathrm{P}_{\mathrm{i}}$ deficiency can result in both bone loss through resorption [6,7] and contribute to myopathy [8] and frailty. Moreover, severe acute hypophosphatemia may cause cardiac and respiratory failure, leading to death [9]. On the other hand, high extracellular $P_{i}$ is similarly associated with adverse health outcomes, including coronary artery calcification, worsening renal function, premature aging, and increased mortality [10-13].

The nutritional environment of Western cultures is, among other features, notable for its very high phosphorus content. This is in no small measure because $P_{i}$ salts are routinely added to processed 
foods for a variety of reasons, including taste and food preservation. The dysregulation of extracellular $P_{i}$ is implicated in skeletal disorders as well as vascular calcification in chronic kidney disease and cardiovascular disease $[14,15]$. This review will examine how dietary phosphorus is absorbed by the body (with an emphasis on recent insights about endocrine regulation of $P_{i}$ homeostasis) and the effects of dietary phosphorus as a nutrient in various organ systems. Additionally, we will examine the effects of dietary phosphorus in longevity and how possible adverse effects may indicate a need for closer examination of the use of $P_{i}$ salts as additives in Western foods. We will highlight areas still poorly understood-for example, the function of $P_{i}$ transporters in dental health, cardiovascular health, and the nature and molecular basis of paracellular $P_{\mathrm{i}}$ absorption in the gut.

\section{Phosphate Absorption from the Diet in the Gut}

The concentrations of phosphorus in sea water or soil are in the micromolar range [16]. Accordingly, the normal situation for unicellular organisms, plants, and certain aqueous animals is that of phosphorus deprivation, for which the uptake and sensing of $P_{i}$ are stimulated by default. It is only when $P_{i}$ is available in higher quantities that this uptake and sensing system is turned off [17]. In higher species (such as fish and mammals), the reverse is the case, since these species can move to seek food to meet their nutrient needs. Particularly for terrestrial mammals and humans, dietary phosphorus is plentiful, and therefore, homeostatic processes that prevent phosphorus intoxication have evolved.

In Western diets, phosphorus (usually as a $P_{i}$ salt) is frequently used as an additive in processed foods $[18,19]$. Recent estimates indicate that phosphorus intakes often exceed the recommended daily allowance (RDA) by one-and-a-half to two-fold [20]; in adults between the ages of 19 and 70, this corresponds to an intake that ranges between 1500 and $1700 \mathrm{mg} /$ day for men and 1000 and $1200 \mathrm{mg} /$ day for women [20]. Intestinal $P_{\mathrm{i}}$ absorption is highest in infancy and childhood and declines with age [21]. However, it remains robust at approximately $50-70 \%$ of bioavailable phosphorus [21]. Of this ingested phosphorus, $16 \mathrm{mg} / \mathrm{kg} /$ day is unidirectionally absorbed in the proximal intestine, and $3 \mathrm{mg} / \mathrm{kg} /$ day is lost through endogenous pancreatic, bile, and gut secretions [22]. The result is a net absorption of $13 \mathrm{mg} / \mathrm{kg} /$ day of phosphorus, which can enter the extracellular fluid and be utilized by tissues such as bone (Figure 1) [22]. The majority of dietary phosphorus is absorbed as $P_{i}$ in the small bowel by two pathways: a passive paracellular pathway and a transcellular absorption pathway. In conditions of abundant dietary $P_{i}$ intake, $70 \%$ of intestinal $P_{i}$ uptake occurs primarily by passive paracellular diffusion, while only $30 \%$ occurs via sodium $\left(\mathrm{Na}^{+}\right)$-dependent, carrier-mediated transcellular transport [21,23-26]. However, in experimental animals, it is estimated that the two pathways contribute roughly equally to intestinal $P_{\mathrm{i}}$ absorption [27].

\subsection{Paracellular Phosphate Absorption Pathway}

In the paracellular absorption pathway, $\mathrm{P}_{\mathrm{i}}$ moves from the diet into the circulation passively through tight junction complexes [30]. However, the specific molecular identities of the components associated with paracellular $P_{i}$ absorption have not been identified. Dietary $P_{i}$ absorption through the paracellular pathway occurs primarily in the small intestine, and to a lesser extent in the colon [31,32]. The permeability for $P_{i}$ in these intestinal segments is similar to $\mathrm{Na}^{+}$[31,32]. Although both monovalent and divalent $P_{i}$ exist under physiological conditions, monovalent $P_{i}$ is slightly preferred for paracellular $P_{i}$ absorption [31]. Although earlier estimates suggest that the paracellular pathway is the major mechanism for $\mathrm{P}_{\mathrm{i}}$ absorption, it is important to note that this pathway is low-affinity. As such, it is sufficient only when phosphorus is present in the diet in high concentrations. The paracellular pathway is also non-saturable, allowing for $P_{i}$ absorption in potentially toxic quantities. Paracellular $P_{i}$ absorption is susceptible to chemical inhibitors, but it is not known to be regulated by hormonal factors (see Section 3, Endocrine regulation of phosphate homeostasis). It is likewise unknown whether paracellular transport is unidirectional or whether it can result in the 'leaking' of $P_{i}$ from the extracellular space into the gut under certain conditions. 
Acute response to high $\mathrm{P}_{\mathrm{i}}$ intake

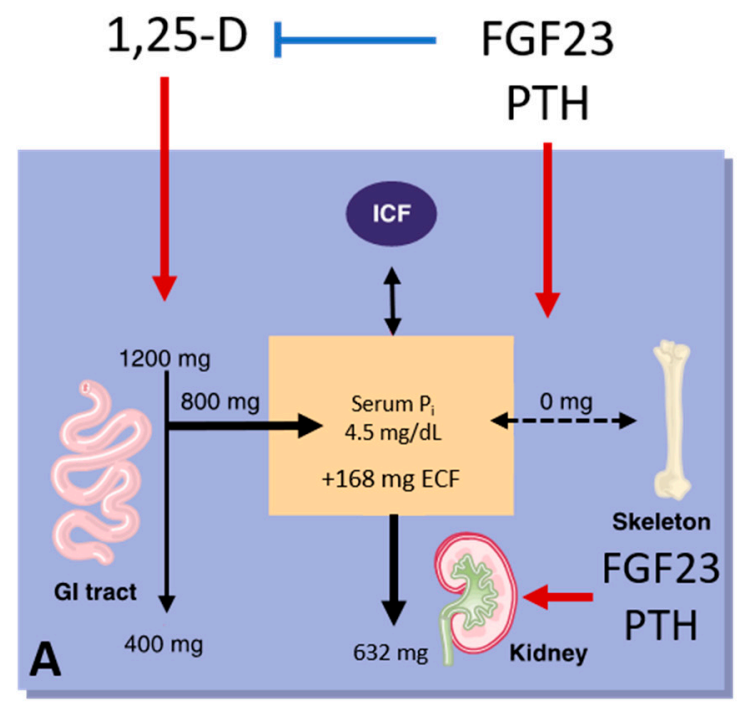

Acute response to low $P_{i}$ intake

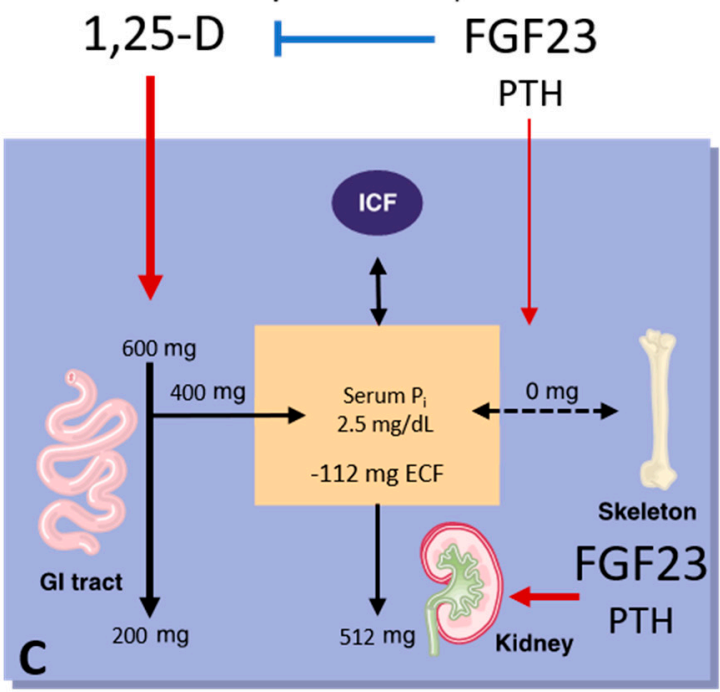

Chronic response to high $\mathrm{P}_{\mathrm{i}}$ intake

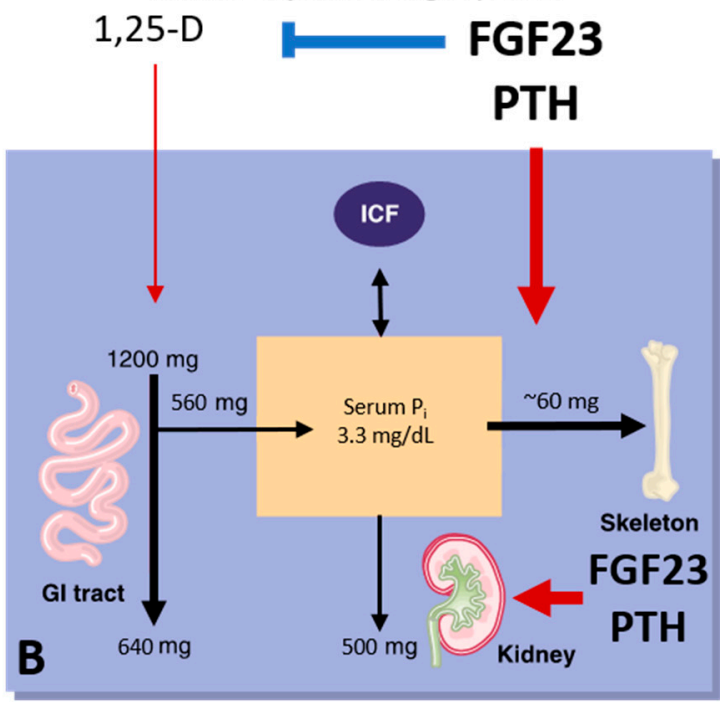

Chronic response to low $\mathrm{P}_{\mathrm{i}}$ intake

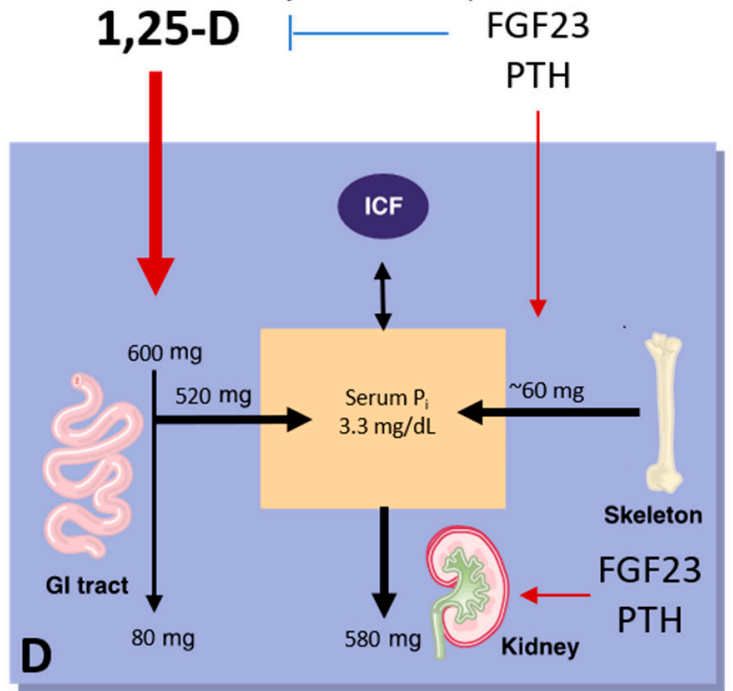

Figure 1. Phosphate homeostasis. (A) The acute response and (B) the chronic response to increases in phosphate intake. (C) The acute response and (D) the chronic response to decreases in phosphate intake. Details are provided in the text. Numbers show hypothetical shifts of phosphorus between body compartments for a $70 \mathrm{~kg}$ adult based on [28]. GI, gastrointestinal. ICF, intracellular fluid. PTH, parathyroid hormone. 1,25(OH $)_{2} \mathrm{D}, 1,25$-dihydroxycholecalciferol (calcitriol). FGF23, fibroblast growth factor 23. $\mathrm{P}_{\mathrm{i}}$, inorganic phosphate. $\mathrm{dL}$, deciliter. $\mathrm{mg}$, milligram. SI conversion: $1 \mathrm{mg}$ phosphorus $=0.32 \mathrm{mmol}$ phosphorus. Adapted from [29].

\subsection{Transcellular Absorption Pathway/Transporter-Mediated Phosphate Absorption}

The second pathway for intestinal $\mathrm{P}_{\mathrm{i}}$ absorption is mediated primarily by the sodium-dependent phosphate transport protein $2 \mathrm{~b}, \mathrm{NPT} 2 \mathrm{~b}$ (encoded by SLC34A2). To a lesser extent, this transcellular transport is also mediated by the type 3 sodium-dependent transporters, PIT1 (encoded by SLC20A1) and PIT2 (encoded by SLC20A2), although the role of the latter is not clear $[21,33]$. This high affinity and saturable transporter-mediated pathway is present in the duodenum and jejunum [34-37], is stimulated by 1,25 -dihydroxyvitamin $\mathrm{D}\left[1,25(\mathrm{OH})_{2} \mathrm{D}\right.$, or calcitriol], and accounts for $30 \%$ of intestinal $\mathrm{P}_{\mathrm{i}}$ absorption when phosphorus is abundant in the diet $[21,34,38,39]$. 
NPT2 $b$ uses the transmembranous $\mathrm{Na}^{+}$gradient to transport $\mathrm{P}_{\mathrm{i}}$ into cells against its own electrochemical gradient at a stoichiometry of $3: 1 \mathrm{Na}^{+}: P_{\mathrm{i}}$ [40]. Both murine $[40,41]$ and swine [42] Npt2b preferentially transport divalent $P_{i}$. The apparent Michaelis-Menten affinity constant $\left(K_{m}\right)$ for murine Npt2b for $P_{i}$ is $10 \mu \mathrm{M}$ at $-60 \mathrm{mV}$, as determined via kinetic characterization in Xenopus oocytes $[40,41]$. This preferential transport of divalent $P_{i}$ also explains why $P_{i}$ uptake via swine NPT2b expressed in Xenopus oocytes increases with alkaline $\mathrm{pH}$ levels and is maximal at $\mathrm{pH} 8.5$ [42].

\section{Endocrine Regulation of Phosphate Homeostasis}

The normal blood concentration of $P_{i}$ in humans is $2.5-4.5 \mathrm{mg} / \mathrm{dL}$ and is regulated through the control of intestinal absorption of $P_{i}$ from the diet, by the release of $P_{i}$ from intracellular stores acutely and from bone remodeling chronically, and renal excretion (reviewed by [14,43-45]). This homeostasis is maintained by parathyroid hormone (PTH), fibroblast growth factor 23 (FGF23), calcitriol, and other factors discussed below. In turn, $P_{i}$ feeds back to regulate the secretion of these hormones. This process is often referred to as endocrine $P_{i}$ sensing [46] but is still poorly understood (for several excellent reviews, see [46-48]).

\subsection{Clinical Chemistry of Phosphate}

Clinical laboratories use differing methods to either measure $P_{i}$ (colorimetric assays) or phosphorus (flame photometry). However, $\mathrm{P}_{\mathrm{i}}$ measurements are converted to phosphorus $\left(1 \mathrm{mg} / \mathrm{dL} \mathrm{P}_{\mathrm{i}}\right.$ contains $0.32 \mathrm{mmol} / \mathrm{L}$ phosphate, which is equal to $0.32 \mathrm{mmol} / \mathrm{L}$ phosphorus). Additionally, it is important to collect fasting samples to determine serum $P_{i}$ levels, since feeding causes hyperinsulinemia, which reduces serum $P_{i}$ levels by inducing intracellular shifts of $P_{i}$ [49]. Moreover, it is also important to consider that the serum concentration of phosphorus follows a circadian rhythm in addition to that modulated by dietary phosphorus; serum phosphorus levels vary throughout the day and are lowest in the early morning [50]. Currently, analysis of serum $P_{i}$ is not a routine measurement in clinical practice; given the potential for adverse health effects caused by high levels of dietary phosphorus and serum $P_{i}$ (discussed later in this review), and the high prevalence of $P_{i}$ additives in Western foods, it may be necessary to reevaluate the importance of such testing.

\subsection{Regulation of Phosphate Absorption in the Gut}

\subsubsection{Calcitriol}

$1,25(\mathrm{OH})_{2} \mathrm{D}$, or calcitriol, is the active form of vitamin $\mathrm{D}$ and the key hormone that regulates transcellular $\mathrm{P}_{\mathrm{i}}$ absorption in the intestine by stimulating the expression of NPT2b. A deficiency of $\mathrm{P}_{\mathrm{i}}$ upregulates calcitriol [6], which will be discussed further in Section 4.3 below. Calcitriol binds to its nuclear hormone receptor vitamin $\mathrm{D}_{3}$ receptor (VDR) [51]. This calcitriol/VDR complex forms nuclear heterodimers with retinoic acid X-receptor (RXR), which then can bind the vitamin D-responsive elements of target genes [51] to regulate gene expression [52-54]. Thereby, calcitriol promotes intestinal $\mathrm{P}_{\mathrm{i}}$ absorption both directly by inducing NPT2b expression in the gut and indirectly by increasing calcium absorption, thereby improving $\mathrm{P}_{\mathrm{i}}$ absorption by preventing the formation of insoluble $\mathrm{CaP}_{\mathrm{i}}$ in the gut lumen $[54,55]$.

\subsubsection{Phosphorus Depletion}

Similar to $1,25(\mathrm{OH})_{2} \mathrm{D}$, dietary phosphorus depletion is considered one of the predominant physiological stimuli of intestinal $P_{\mathrm{i}}$ absorption $[25,39,56]$. Chronic adaptation to a low-phosphate diet in wild-type (WT) rats appears to go along with the upregulation of $N p t 2 b$ in the jejunum and upregulation of $N p t 2 a$ in the proximal tubules, where the bulk of filtered $P_{i}$ is reabsorbed [25,37,57-59]. However, it appears that low- $\mathrm{P}_{\mathrm{i}}$-diet-induced $\mathrm{Npt} 2 \mathrm{~b}$ upregulation is independent of the $1,25(\mathrm{OH})_{2} \mathrm{D}-\mathrm{VDR}$ axis [60]. This was shown in mice that had a normal upregulation of $\mathrm{Npt} 2 \mathrm{~b}$ by a low- $\mathrm{P}_{\mathrm{i}}$ diet despite being VDR- and 1- $\alpha$ hydroxylase-deficient [60]. Additionally, low dietary phosphorus increases the 
activity of NPT2b by post-transcriptional mechanisms $[18,21]$ and mobilizes $P_{i}$ from the bone mineral via increased resorption [7].

\subsubsection{Estrogen}

Similar to calcitriol, estrogen increases $\mathrm{Na}^{+}$-dependent $\mathrm{P}_{\mathrm{i}}$ absorption in the gut. In response to estrogen treatment, $\mathrm{Xu}$ et al. showed increased brush border membrane vesicle (BBMV) $\mathrm{P}_{\mathrm{i}}$ uptake accompanied by an increased abundance of $\mathrm{Npt} 2 \mathrm{~b}$ protein in rat intestine [61]. Further, estrogen treatment also increases $N p t 2 b$ mRNA levels in rats, suggesting transcriptional upregulation of the gene encoding Npt2b in response to estrogen [61]. A similar result was found using human intestinal epithelial (Caco-2) cells [61].

\subsubsection{Glucorticoids}

Glucocorticoids (GCs) inhibit $P_{\mathrm{i}}$ uptake in the intestine. Methylprednisolone injection in suckling animals resulted in a 3-4-fold reduction of NPT2b protein and mRNA levels, which reduced $\mathrm{Na}^{+}-\mathrm{P}_{\mathrm{i}}$ uptake [62]. This suggests a possible regulatory role for GCs at the transcriptional level. However, other work done demonstrated that GC injection resulted in increased fucosyl transferase activity in suckling rat intestine $[62,63]$. This finding suggests a role for corticoids in intestinal maturation and the regulation of NPT2b glycosylation in a non-genomic fashion $[62,63]$.

\subsubsection{Epidermal Growth Factor}

Epidermal growth factor (EGF) similarly inhibits intestinal $P_{\mathrm{i}}$ absorption. EGF decreased promoter activity in Caco-2 cells transfected with human NPT2b promoter constructs and also decreased NPT2b mRNA abundance in both Caco- 2 and rat intestinal cells by $40-50 \%$, indicating that EGF transcriptionally downregulates NPT2b [64]. The molecular basis for this effect is that EGF reduces the binding affinity of the v-myb avian myeloblastosis viral oncogene homolog (c-myb) for the EGF responsive element in the NPT2b gene promoter [65], resulting in decreased promoter activity and therefore reduced $N P T 2 b$ mRNA abundance [65]. Additionally, $\mathrm{Xu}$ et al. found that this regulatory effect involves EGF receptor-mediated activation of the mitogen-activated protein kinase (MAPK), protein kinase $C$ (PKC), and protein kinase A (PKA) pathways [65].

\section{Regulation of Systemic Phosphate Homeostasis}

\subsection{PTH}

PTH is a peptide of 84 amino acids that is secreted by the parathyroid glands and signals through the PTH and PTH-related protein receptor [(also known as parathyroid hormone receptor 1 (PTHR1)], which is expressed in osteoblasts, osteocytes, chondrocytes, and proximal tubular cells [46]. $\mathrm{P}_{\mathrm{i}}$ stimulates the secretion of PTH in the parathyroids, which in turn stimulates the synthesis of calcitriol in the proximal tubules and thereby indirectly stimulates intestinal $P_{i}$ absorption [66]. Additionally, PTH stimulates bone turnover, resulting in the release of $P_{i}$ from the skeleton $[67,68]$. However, the net effect of PTH is to lower blood levels of $\mathrm{P}_{\mathrm{i}}$ because PTH also reduces the stability of the type II $\mathrm{Na}^{+}-\mathrm{P}_{\mathrm{i}}$ co-transporters (NPT2a and NPT2c) at the renal brush border membrane, which reduces the reabsorption of $P_{i}$ from the urine $[69,70]$. This process is mediated by $\mathrm{Na}^{+} / \mathrm{H}^{+}$exchange regulatory cofactor 1 (NHERF-1), which exists as a complex with NPT2a at the apical membrane of the proximal tubular cells [69,71]. NHERF-1 is phosphorylated via the cyclic adenosine monophosphate-PKA and phospholipase C-PKC signal transduction pathways following the activation of PTHR1 [21,69,71].

\subsection{FGF23}

FGF23 is a member of the fibroblast growth factor (FGF) family that is produced by osteocytes and osteoblasts in the skeleton [72-74], and it stimulates $P_{i}$ excretion in the kidneys [75]. This most recently identified physiologic regulator of renal $P_{\mathrm{i}}$ excretion [76] provides a mechanism by which 
skeletal mineral demands can be communicated to the kidney. Thus, the skeleton can influence the $P_{i}$ economy of the entire organism through FGF23. Dietary $P_{i}$, particularly when present in excess amounts, stimulates the synthesis of FGF23 [77]. In turn, FGF23 reduces the expression of NPT2a and NPT2c and thereby reduces $P_{i}$ reabsorption [78]. This process requires binding of the C-terminal tail of FGF23 to the klotho 1 and klotho 2 domains of $\alpha$-Klotho (KL, which functions as a co-receptor) [79]. Additionally, binding of the FGF-like N-terminal domain to isoform c of FGF receptor 1 (FGFR1c) is also required [79]. Dimerization of this FGF23-KL-FGFR1c heterotrimer by heparan sulfate [79] is required for the activation of the extracellular signal-regulated kinases 1 and 2 (ERK1/2) [80]. Then, activation of ERK1/2 results in NHERF-1 dependent internalization of NPT2a and NPT2c from the apical membrane of proximal tubular cells in the kidneys [81]. Additionally, FGF23 reduces the expression of CYP27B1 (encoding CYP27B1, the 25-hydroxy-vitamin D 1- $\alpha$ hydroxylase that synthesizes calcitriol) and stimulates the expression of CYP24A1 (encoding CYP24A1, the vitamin D 24-hydroxylase that degrades calcitriol) $[82,83]$. As such, FGF23 inhibits the synthesis of calcitriol $[82,83]$. The net effect of this NPT2a/c internalization and decreased circulating calcitriol levels is lower blood levels of $\mathrm{P}_{\mathrm{i}}$.

\subsection{Calcitriol}

Calcitriol is the active metabolite of vitamin $\mathrm{D}$ as mentioned above. Its synthesis by CYP27B1 and degradation by CYP24A1 are regulated by PTH, FGF23, calcium, and $\mathrm{P}_{\mathrm{i}}$ [54]. PTH stimulates calcitriol synthesis by inducing the expression of CYP27B1 and by suppressing the expression of CYP24A1 [54]. FGF23 decreases calcitriol levels by suppressing the expression of CYP27B1 and stimulating the expression of CYP24A1 [46,84]. In turn, calcitriol increases FGF23 levels, forming a negative feedback loop. The actions of $P_{i}$ and calcium on calcitriol synthesis are predominantly mediated by FGF23 and PTH, respectively [85-89]. Additionally, calcitriol inhibits PTH both directly by transcriptionally repressing the gene encoding PTH and indirectly by upregulating the calcium-sensing receptor (CASR, a protein that modulates PTH secretion by calcium in the parathyroid cells) [51]. Calcitriol, as mentioned already above, stimulates NPT2b expression in the intestine and thereby increases both the absorption of $P_{i}$ in the gut and consequently circulating blood $P_{i}$ levels [55]. Since it suppresses $\mathrm{PTH}$, calcitriol also indirectly reduces $\mathrm{P}_{\mathrm{i}}$ excretion in the kidneys. Therefore, the net effect of calcitriol is to increase blood $\mathrm{P}_{\mathrm{i}}$.

\section{Disorders of Phosphate Homeostasis}

In this review, we will focus on disorders of intestinal $P_{i}$ absorption, which can be divided into disorders of intake, bioaccessibility, bioavailability, and regulatory hormones. While generally acquired, some of these disorders have underlying genetic causes (as reviewed below). If left untreated, dietary phosphorus insufficiency can result in rickets or osteomalacia $[90,91]$. Furthermore, a prolonged reduction of serum $P_{i}$ levels $<1.0 \mathrm{mg} / \mathrm{dL}$ can result in several more health issues, including rhabdomyolysis, cardiac muscle dysfunction with congestive heart failure, and leukocyte dysfunction, among other abnormalities [92-94]. Excess blood $P_{i}$ can lead to tissue calcifications and excess syndromes caused by hyperparathyroidism and high circulating FGF23 levels. The effects of dietary phosphorus deficiency or excess will be discussed in detail for each tissue in the next chapters.

\subsection{Phosphorus Content in the Western Diet}

Phosphorus is abundant in the Western diet. The RDA for phosphorus from the diet is $700 \mathrm{mg} /$ day [20]. However, most Americans far exceed this recommendation [20], since a lack of mandated reporting on nutrition facts labels causes phosphorus content to be commonly unidentified on American food labels [95]. Phosphorus additives tend to be common in prepared frozen foods, dry mixes, packaged meats, bread and baked goods, and some yogurts (where $P_{i}$ additives may be added in addition to the phosphorus contributed by milk) [96]. These additives mainly consist of phosphoric acid, phosphates, or polyphosphates [97], and they were found on average to add $736 \mathrm{mg}$ more phosphorus/day compared to additive-free diets [96]. Even in balanced $2200 \mathrm{kcal} /$ day diets, 
phosphorus consumption as averaged over four days totaled $1677 \pm 167 \mathrm{mg} /$ day in additive-enhanced diets [98]. In low-additive diets designed to meet U.S. Department of Agriculture recommended guidelines for fat, protein, carbohydrate, and phosphorus intake, the averaged total was $1070 \pm 58 \mathrm{mg}$ phosphorus/day [98]. When separately evaluated by gender, males aged 19-70 have an average daily phosphorus intake that ranges between 1500 and $1700 \mathrm{mg}$, and women aged 19-70 usually consume between 1000 and $1200 \mathrm{mg}$ phosphorus/day [20].

Similarly, phosphorus intake in Europe averages $1000-1767 \mathrm{mg} /$ day for both sexes [99]. This elevated intake may also be due to unclear phosphorus labeling since, in Europe, information about phosphorus is generally only available in the ingredients list [100]. However, even in this case, phosphorus may be listed as different $P_{i}$ additives or identified only by $E$ number (a code assigned to food additives in Europe) [100].

National Health and Nutrition Examination Survey data demonstrated an association between high dietary phosphorus intake ( $>1400 \mathrm{mg} /$ day) and all-cause mortality in U.S. adults after adjusting for other known contributors [101]. This threshold of $1400 \mathrm{mg} /$ day is routinely exceeded by men aged 14-71 in the U.S., suggesting a negative effect of high dietary phosphorus on human longevity [20].

In addition to attention to labeling and phosphorus content in the diet, physicians need to be aware that therapeutic phosphorus preparations often list the mass of the phosphate salt, which includes oxygen, sodium, and potassium. Therefore, phosphorus content varies for the specific preparation being prescribed, and this should be considered in consultation with the pharmacist and hospital formulary (Table 1) [21].

Table 1. Clinician's Guide to $\mathrm{P}_{\mathrm{i}} /$ Vitamin D Supplementation ${ }^{1}$.

\begin{tabular}{|c|c|c|c|}
\hline Phosphate Preparations & Phosphorus Content & Potassium (K) Content & Sodium (Na) Content \\
\hline $\begin{array}{l}\text { Neutraphos-powder } \\
\text { (for mixing with liquid) }\end{array}$ & $250 \mathrm{mg} /$ packet & $270 \mathrm{mg} /$ packet & $164 \mathrm{mg} /$ packet \\
\hline $\begin{array}{l}\text { Neutraphos-K-powder } \\
\text { (for mixing with liquid) }\end{array}$ & $250 \mathrm{mg} /$ packet & $556 \mathrm{mg} /$ packet & $0 \mathrm{mg} /$ packet \\
\hline $\begin{array}{l}\text { K-Phos Original-tablet } \\
\text { (to mix in liquid, acidifying) }\end{array}$ & $114 \mathrm{mg} /$ tablet & $144 \mathrm{mg} /$ tablet & $0 \mathrm{mg} /$ tablet \\
\hline $\begin{array}{l}\text { K-Phos MF-tablet } \\
\text { (mixing not } \\
\text { required, acidifying) }\end{array}$ & $126 \mathrm{mg} /$ tablet & $45 \mathrm{mg} / \mathrm{tablet}$ & $67 \mathrm{mg} / \mathrm{tablet}$ \\
\hline $\begin{array}{c}\text { K-Phos \#2 } \\
\text { (double strength of } \\
\text { K-Phos MF) }\end{array}$ & $250 \mathrm{mg} /$ tablet & $90 \mathrm{mg} / \mathrm{tablet}$ & $133 \mathrm{mg} /$ tablet \\
\hline $\begin{array}{l}\text { K-Phos Neutral-tablet } \\
\text { (non-acidifying, } \\
\text { mixing not required) }\end{array}$ & $250 \mathrm{mg} /$ tablet & $45 \mathrm{mg} / \mathrm{tablet}$ & $298 \mathrm{mg} /$ tablet \\
\hline $\begin{array}{l}\text { Phospha-Soda-solution } \\
\text { (small doses may be } \\
\text { given undiluted) }\end{array}$ & $127 \mathrm{mg} / \mathrm{mL}$ & $0 \mathrm{mg} / \mathrm{mL}$ & $152 \mathrm{mg} / \mathrm{mL}$ \\
\hline $\begin{array}{c}\text { Joulie's solution } \\
\text { (prepared by } \\
\text { compounding pharmacies) }\end{array}$ & $30 \mathrm{mg} / \mathrm{mL}$ & $0 \mathrm{mg} / \mathrm{mL}$ & $17.5-20 \mathrm{mg} / \mathrm{mL}$ \\
\hline $\begin{array}{l}\text { Vitamin D and } \\
\text { Related Agents }\end{array}$ & \multicolumn{2}{|c|}{ Agent } & Available Preparations \\
\hline Vitamin D & \multicolumn{2}{|c|}{ Calciferol (Drisdol) } & $\begin{array}{c}\text { Solution: } 8000 \mathrm{IU} / \mathrm{mL} \\
\text { Tablets: } 25,000 \text { and } \\
50,000 \mathrm{IU}\end{array}$ \\
\hline Dihydrotachysterol & \multicolumn{2}{|c|}{ DHT (Hytakerol) } & $\begin{array}{l}\text { Solution: } 0.2 \mu \mathrm{g} / 5 \mathrm{~mL} \\
\text { Tablets: } 0.125,0.2, \\
\text { and } 0.4 \mathrm{mg}\end{array}$ \\
\hline
\end{tabular}


Table 1. Cont.

\begin{tabular}{ccc}
\hline $\begin{array}{c}\text { Vitamin D and } \\
\text { Related Agents }\end{array}$ & Agent & Available Preparations \\
\hline \multirow{2}{*}{1,25 dihydroxyvitamin D } & Calcitriol (Rocaltrol) & $\begin{array}{c}0.25 \text { and } 0.5 \mu \mathrm{g} \text { capsules } \\
\text { and } 1 \mu \mathrm{g} / \mathrm{mL} \text { solution }\end{array}$ \\
\cline { 2 - 3 } $1 \alpha$-hydroxyvitamin D & Calcijex & $\begin{array}{c}\text { Ampules for IV use containing } \\
1 \text { or } 2 \mu \mathrm{g} \text { of drug per } \mathrm{mL}\end{array}$ \\
\hline Vitamin D analogs & Alfacalcidol & $\begin{array}{c}0.25,0.5, \text { and } 1 \mu \mathrm{g} \text { capsules } \\
\text { Oral solution (drops): } 2 \mu \mathrm{g} / \mathrm{mL}\end{array}$ \\
\cline { 2 - 3 } & & Solution for IV use: $2 \mu \mathrm{g} / \mathrm{mL}$ \\
\hline
\end{tabular}

${ }^{1}$ SI conversion: $1 \mathrm{mg}$ phosphorus $=0.32 \mathrm{mmol}$ phosphorus, $1 \mu \mathrm{g}$ vitamin $\mathrm{D}=40 \mathrm{IU}$ vitamin D. IU, international unit. IV, intravenous. From: [102].

\subsection{Influence of Dietary Components and Drugs on the Bioaccessibility of Phosphate}

Of course, dietary phosphorus deficiency leads to a total body $P_{i}$ deficiency. Furthermore, several dietary components can have a pronounced effect on the bioaccessibility of $P_{i}$. When combined with an insulin-mediated cellular change in $P_{i}$ during refeeding, total body $P_{i}$ deficiency causes hypophosphatemia (defined as serum $P_{i}$ levels below $2.5 \mathrm{mg} / \mathrm{dL}$, and it is considered severe at levels below $1.5 \mathrm{mg} / \mathrm{dL}$ ) [50,103]. Refeeding syndrome can cause severe hypophosphatemia in malnourished individuals with alcoholism as well in intensive care or institutionalized individuals [49]. However, hypophosphatemia is rare in the general population, since phosphorus is ubiquitous in the Western diet (as already mentioned above) [98]. In turn, high dietary phosphorus intakes as high as $4000 \mathrm{mg} /$ day result in only minor increases in serum $P_{i}$ concentrations due to the high efficiency of renal excretion [104], provided that ingestion is spread throughout the day. However, undiluted cow's milk can provide sufficiently high $P_{i}$ to induce hyperphosphatemia in infants [15]. Moreover, bowel preparations that use $\mathrm{P}_{\mathrm{i}}$-containing laxatives (such as oral phosphosodas) can result in severe hyperphosphatemia and in some cases renal failure due to nephrocalcinosis $[105,106]$.

$\mathrm{pH}$ is also an important factor controlling the bioaccessibility of $\mathrm{P}_{\mathrm{i}}$ from the diet in the gut. At $\mathrm{pH}$ values above 6.5, dibasic $\mathrm{P}_{\mathrm{i}}$ predominates but has low solubility $(30 \mathrm{mg} / \mathrm{dL})[107,108]$. At $\mathrm{pH}$ values below 6.5, monobasic $P_{i}$ predominates with a much higher solubility $(1800 \mathrm{mg} / \mathrm{dL})[107,108]$. In a study of infants who were fed an elemental diet and exhibited unexplained hypophosphatemia, a commonality between many children was treatment with gastric proton pump inhibitors (PPIs) [109]. The effect of this treatment would have likely been abnormally high gastric $\mathrm{pH}$ [109]. Given that $\mathrm{P}_{\mathrm{i}}$ solubility decreases with increasing $\mathrm{pH}$ (particularly above the acidic range), it is possible that increased gastric $\mathrm{pH}$ could have resulted in reduced mineral absorption [108,109]. However, it should be noted that the authors did not identify systemic acid-base abnormalities in these children, and $P_{i}$ status was corrected with alternative Pi salts rather than an alteration of acid-modifying medications [109]. Similarly, alkaline $\mathrm{pH}$ inhibits $\mathrm{P}_{\mathrm{i}}$ transport in rat intestinal BBMVs [110]. Conversely, acidic $\mathrm{pH}$ increases $P_{i}$ uptake in rat intestinal BBMVs, and this might be partially mediated by an unidentified, $\mathrm{Na}^{+}$-coupled $P_{i}$ transporter that prefers monovalent $P_{i}[110]$.

Certain antacids, such as magnesium-aluminum hydroxides, sucralfate, and calcium-containing antacids, can also reduce the bioaccessibility of $P_{i}[111,112]$. These antacids reduce $P_{i}$ bioaccessibility by binding to dietary $P_{i}$ and by forming insoluble $P_{i}$ salts in the small intestine that prevent absorption [111,112]. Thus, prolonged use of $\mathrm{P}_{\mathrm{i}}$-binding antacids can cause hypophosphatemia [111].

Phytate, which is the major form of phosphorus in the seeds of plants, is a compound that can form indigestible mineral phytate salts in humans (who lack the enzyme phytase that can release $P_{i}$ from phytate) [113]. At physiological $\mathrm{pH}$, phytate binds calcium with high affinity [114]. If the calcium concentration is high, phytate forms indigestible, multiple calcium phytate salts [113]. However, 
phytate becomes digestible at low calcium concentrations due to reduced calcium binding [113]. Kim et al. demonstrated that high phytate/low calcium diets increase intestinal $P_{i}$ absorption in rats following intestinal phytate hydrolysis that makes $P_{i}$ bioaccesible [113]. This $P_{i}$ load results in secondary hyperparathyroidism and renal $P_{i}$ wasting, which appears to be independent of FGF23 [113]. Calcium supplementation alleviates this effect [113]. Therefore, attention to dietary calcium may be especially important in vegetarians or other individuals who consume high-phytate diets to avoid hyperphosphatemia and its associated effects.

\subsection{Influence of Dietary Components, Drugs, and Disorders on the Bioavailability of Phosphate}

There exist a variety of molecules containing a $P_{i}$ moiety that can act as competitive inhibitors of NPT2b and thereby inhibit intestinal $P_{i}$ transport. Phosphonoformate (PFA, a phosphonocarboxylate) has a $K_{i}$ value of $0.37 \mathrm{mM}$ in rat small intestine BBMVs, which indicates a low affinity of NPT2b for PFA as compared to $P_{i}[115]$. 2'-Phosphophloretin (2'-PP), a derivative of the plant chalcone phloretin, more strongly inhibits $\mathrm{Na}^{+}$-dependent $\mathrm{P}_{\mathrm{i}}$ uptake, with $\mathrm{K}_{\mathrm{i}}$ values of $38 \pm 7 \mathrm{nM}$ in rabbit intestinal BBMVs and $42 \pm 8 \mathrm{nM}$ in rat intestinal BBMVs [116]. Pentavalent arsenate can be transported by NPT2b and also acts as a competitive inhibitor of NPT2b ( $\mathrm{K}_{\mathrm{i}}=51 \mu \mathrm{M}$ for rat Npt2b in Xenopus oocytes) [115]. Of course, the inhibition of intestinal $P_{i}$ transport would reduce $P_{i}$ bioavailability.

On the other hand, nicotinamide adenine dinucleotide (NAD) acts as a non-competitive inhibitor of intestinal $P_{\mathrm{i}}$ transport in vivo [117]. Similarly, triazole derivatives also act in a non-competitive fashion, inhibiting up to $61 \%$ of intestinal $P_{i}$ absorption as measured by in vivo experiments $[118,119]$. Finally, although tenapanor is not a direct inhibitor of NPT2b, repeat administration of tenapanor reduces transcellular $P_{i}$ absorption by decreasing the apical membrane expression of NPT2b at the small intestine [120]. This effect occurs at the transcriptional level [120]. These molecules and their effects on intestinal $P_{i}$ absorption are described in further detail in several excellent reviews $[31,33,118]$.

There are no known competitive inhibitors of paracellular $P_{i}$ absorption in the intestine, which relies on passive diffusion and, differently from transporter-mediated absorption, is non-saturable. However, a notable non-competitive inhibitor of paracellular $P_{i}$ transport is Tenapanor. Tenapanor increases transepithelial electrical resistance (TEER) of the sodium/hydrogen exchanger isoform 3 (NHE3, encoded by SLC9A3) [120]. This increase in TEER reduces tight junction permeability to $P_{i}$ and therefore reduces intestinal $P_{i}$ absorption [120]. Since paracellular $P_{i}$ absorption is the major mechanism by which $P_{i}$ is absorbed when it is abundant in the diet, drugs that target paracellular rather than transcellular $P_{i}$ absorption could be as effective at preventing hyperphosphatemia in conditions such as chronic kidney disease (CKD) as $P_{i}$ binders. The development of such drugs could be aided by the identification of $\mathrm{P}_{\mathrm{i}}$-specific occludins and claudins. Additionally, it would be interesting to know if leaky gut, whereby $P_{i}$ is lost through the paracellular route, can occur in humans (perhaps in situations where drugs or other causes reduce the concentration of $P_{i}$ in the intestinal lumen such that $P_{i}$ flows outward into the lumen).

Vitamin D intoxication caused by acute doses of vitamin D $>10,000$ international units (IU)/day and potentially chronically through extended administration of doses $>4000$ IU/day [121,122] increases intestinal $P_{i}$ absorption via the upregulation of NPT2b $[54,55]$ and also increases bone resorption $[7,123]$. Both factors can contribute to the development of hyperphosphatemia. Additionally, high levels of calcitriol inhibit the production of PTH, thereby blunting PTH-mediated removal of NPT2a/c from the renal proximal tubules $[66,124]$. This effect contributes to hyperphosphatemia due to reduced renal $P_{i}$ excretion [66,124]. Conversely, vitamin D deficiency causes decreased intestinal $P_{i}$ absorption, resulting in rickets or osteomalacia as well as secondary hyperparathyroidism $[125,126]$.

Finally, certain diseases and conditions can also affect $P_{i}$ bioavailability. Inflammatory bowel diseases are often characterized by chronic diarrhea [127] and result in the malabsorption of $P_{i}$ [128]. Conversely, metabolic acidosis causes increased NPT2b abundance in mouse small intestinal BBMVs, although this increase is not accompanied by a corresponding increase in NPT2b mRNA [129]. As a 
result, metabolic acidosis increases $P_{i}$ uptake, potentially to buffer acid equivalents and contribute to the restoration of acid-base homeostasis [129].

Acquired disorders of $P_{i}$ homeostasis are summarized below in Table 2.

Table 2. Acquired Disorders of Phosphate Homeostasis ${ }^{1}$.

\begin{tabular}{|c|c|c|}
\hline Disorder & Mechanism & Ref. \\
\hline \multicolumn{3}{|l|}{ Hypophosphatemic } \\
\hline Dietary phosphorus deficiency & $\begin{array}{l}\text { Total body deficiency, combined with an } \\
\text { insulin-mediated cellular shift in } P_{i} \text { during } \\
\text { refeeding, causes hypophosphatemia. }\end{array}$ & [50] \\
\hline Vitamin D deficiency & $\begin{array}{l}\text { Reduced intestinal } \mathrm{Ca} \text { and } \mathrm{P}_{\mathrm{i}} \text { absorption } \\
\text { causes rickets/osteomalacia and secondary } \\
\text { hyperparathyroidism. }\end{array}$ & {$[130,131]$} \\
\hline $\begin{array}{l}\text { Chronic use of } \mathrm{P}_{\mathrm{i}} \text { antacids/high gastric } \mathrm{pH} \\
\text { (due to PPIs, autoimmune gastritis/pernicious } \\
\text { anemia, etc.) }\end{array}$ & $\begin{array}{l}\text { High gastric } \mathrm{pH} \text { reduces } \mathrm{P}_{\mathrm{i}} \text { solubility, which } \\
\text { potentially results in reduced mineral } \\
\text { absorption and hypophosphatemia. }\end{array}$ & {$[109,111,112,132,133]$} \\
\hline $\begin{array}{l}\text { Reduced gastrointestinal absorption (due to } \\
\text { Inflammatory Bowel and Celiac diseases, } \\
\text { diarrhea, vomiting, short gut, intestinal } \\
\text { mucosal hypoplasia, jejunal feeding, } \\
\text { prematurity, etc.) }\end{array}$ & $\begin{array}{l}\text { Chronic diarrhea and reduced gastrointestinal } \\
\text { absorption of } P_{\mathrm{i}} \text { reduce bioavailable } \mathrm{P}_{\mathrm{i}} \text {. }\end{array}$ & {$[127,128]$} \\
\hline Parenteral iron administration & $\begin{array}{l}\text { Ferric carboxymaltose blocks FGF23 cleavage, } \\
\text { which induces renal } P_{\mathrm{i}} \text { wasting. }\end{array}$ & [134] \\
\hline $\begin{array}{l}\text { Proximal tubular damage (caused by renal } \\
\text { tubular acidosis or drugs such as } \\
\text { theophylline, foscarnet) }\end{array}$ & $\begin{array}{l}\text { Renal Pi wasting causes rickets/osteomalacia } \\
\text { and hypercalciuria. }\end{array}$ & [135-137] \\
\hline Hyperparathyroidism & $\begin{array}{l}\text { Bone resorption increases serum } P_{i} \text {, but the } \\
\text { net effect is to lower serum } P_{i} \text { due to } \\
\text { increased renal excretion. }\end{array}$ & {$[138,139]$} \\
\hline \multicolumn{3}{|l|}{ Drugs } \\
\hline $\begin{array}{l}\text { Phosphonocarboxylates (e.g., PFA), phloretin } \\
\text { derivatives (e.g., 2'-PP), arsenate }\end{array}$ & $\begin{array}{l}\text { Competitively inhibit Na- } P_{i} \text { co-transport } \\
\text { of } P_{i} \text {. }\end{array}$ & {$[115,116,118,140]$} \\
\hline $\begin{array}{l}\text { Niacin/Nicotinamide, } \\
\text { NAD, triazole derivatives }\end{array}$ & $\begin{array}{l}\text { Downregulates NPT2b, inhibits intestinal } \\
P_{\mathrm{i}} \text { transport. }\end{array}$ & {$[117,118,141]$} \\
\hline Tenapanor & $\begin{array}{l}\text { Inhibits paracellular } P_{i} \text { transport and } \\
\text { downregulates NPT2b. }\end{array}$ & {$[118,120]$} \\
\hline Insulin & $\begin{array}{l}\text { Promotes } P_{i} \text { uptake into tissues. Can result in } \\
\text { hypophosphatemia in the context } \\
\text { of refeeding. }\end{array}$ & {$[103,142]$} \\
\hline $\begin{array}{l}\text { Bisphosphonates and other bone } \\
\text { resorption blockers }\end{array}$ & $\begin{array}{l}\text { Decreased bone resorption can cause } \\
\text { hypophosphatemia along with hypocalcemia. }\end{array}$ & {$[143,144]$} \\
\hline Adriamycin & $\begin{array}{l}\text { Inhibits } P_{i} \text { transport by PIC in } \\
\text { reconstituted liposomes. }\end{array}$ & [145] \\
\hline \multicolumn{3}{|l|}{ Hyperphosphatemic } \\
\hline High phytate/low $\mathrm{Ca}^{2+}$ diet & $\begin{array}{l}\text { Low dietary } \mathrm{Ca}^{2+} \text { causes } \mathrm{P}_{\mathrm{i}} \text { hyperabsorption. } \\
\text { The associated homeostatic response induces } \\
\text { secondary hyperparathyroidism. }\end{array}$ & [113] \\
\hline Tumor lysis syndrome and rhabdomyolysis & $\begin{array}{l}\text { Release of intracellular } P_{i} \text { from lysed cells } \\
\text { may result in hyperphosphatemia. }\end{array}$ & {$[146,147]$} \\
\hline Bone metastases & $\begin{array}{l}\text { Tumor metastasis can increase bone } \\
\text { resorption, which may result in } \\
\text { hyperphosphatemia and hypercalcemia. }\end{array}$ & [148] \\
\hline Kidney failure (e.g., CKD) & $\begin{array}{l}\text { Reduced number of nephrons decreases renal } \\
\mathrm{P}_{\mathrm{i}} \text { excretion, resulting in hyperphosphatemia. }\end{array}$ & [149] \\
\hline Lowered gastric $\mathrm{pH}$ & $\begin{array}{l}\text { May increase } P_{i} \text { bioaccessibility and } \\
P_{i} \text { absorption. }\end{array}$ & {$[107,108,110]$} \\
\hline
\end{tabular}


Table 2. Cont.

\begin{tabular}{|c|c|c|}
\hline Disorder & Mechanism & Ref. \\
\hline \multicolumn{3}{|l|}{ Drugs } \\
\hline Vitamin D & $\begin{array}{l}\text { Increases intestinal absorption of } \mathrm{Ca} \text { and } \mathrm{P}_{\mathrm{i}} \\
\text { increases bone resorption, suppresses } \mathrm{PTH}, \\
\text { and thereby reduces renal excretion of } \mathrm{P}_{\mathrm{i}} \\
\text { all of which contribute to } \\
\text { hyperphosphatemia. }\end{array}$ & {$[7,54,55,66,124]$} \\
\hline$P_{i}$ supplementation & $\begin{array}{l}\mathrm{P}_{\mathrm{i}} \text {-containing laxatives can induce severe } \\
\text { hyperphosphatemia, nephrocalcinosis, } \\
\text { and renal failure. }\end{array}$ & {$[105,106]$} \\
\hline Pharmaceutical agents increase serum $P_{i}$ & Refer to Table 1. & \\
\hline FGFR Inhibitors & Inhibit renal FGF23 signaling. & [150] \\
\hline \multicolumn{3}{|c|}{$\begin{array}{l}1 \text { Table modified from [46]. Gray background color was implemented to provide a visual boundary between } \\
\text { hypophosphatemic and hyperphosphatemic categorization. Bold font was used to visually denote the boundary } \\
\text { between drug-related and other disorders. Ca/Ca } \mathrm{Ca}^{2+} \text {, calcium. } \mathrm{P}_{\mathrm{i}} \text {, inorganic phosphate. Na, sodium. PPI, proton pump } \\
\text { inhibitor. FGF23, fibroblast growth factor } 23 \text {. PFA, phosphonoformic acid. } 2^{\prime}-\mathrm{PP}, 2^{\prime}-\mathrm{phosphophloretin} \text {. NAD } \\
\text { nicotinamide adenine dinucleotide. NPT2b, type IIB sodium-dependent phosphate cotransporter. PIC, mitochondrial } \\
\text { phosphate carrier. CKD, chronic kidney disease. PTH, parathyroid hormone. FGFR, fibroblast growth factor receptor. }\end{array}$} \\
\hline
\end{tabular}

\subsection{Genetic Disorders of Intestinal Phosphate Absorption}

In addition to acquired disorders, there are several genetic disorders of intestinal $\mathrm{P}_{\mathrm{i}}$ absorption that concern the active, transcellular transport of $P_{i}$. Thus far, no genetic abnormalities affecting the passive, paracellular transport of $P_{i}$ have been reported.

The key protein involved in active intestinal $P_{i}$ transport is NPT2b [35]. NPT2b deletion is embryonic lethal in mice, and homozygous loss of function (LOF) mutations of NPT2b in humans cause pulmonary alveolar and testicular microlithiasis [151,152]. On the other hand, genetic disorders of vitamin D synthesis or action can impair intestinal $P_{i}$ absorption. Hereditary $1,25(\mathrm{OH})_{2}$ D-resistant rickets (HVDDR) is characterized by mutation in the VDR gene, which results in vitamin $D$ resistance [153]. As a result of this vitamin D resistance, HVDDR symptoms include hypophosphatemia, hypocalcemia, secondary hyperparathyroidism, and severe rickets with osteomalacia [153]. Similarly, vitamin D-resistant rickets type 1A is characterized by mutation in CYP27B1 [154]. Thus, this disorder causes calcitriol deficiency, which results in hypophosphatemia, hypocalcemia, and rickets $[15,154]$.

Although LOF mutations in claudins and occludins that affect the paracellular transport of other minerals (such as magnesium) have been described, no disorders caused by LOF mutations in $\mathrm{P}_{\mathrm{i}}$-specific tight junction proteins have been reported thus far.

\subsection{Other Disorders of Phosphate Homeostasis}

For the large number of disorders of $P_{i}$ homeostasis that do not concern $P_{i}$ as a nutrient (listed in Table 3 and visually in Figure 2), the reader is referred to several excellent recent reviews [15,21,155]. These disorders can be broadly divided into disorders of extracellular $P_{i}$ homeostasis or disorders of intracellular $P_{i}$ homeostasis. Disorders of extracellular $P_{i}$ homeostasis can be further categorized as being FGF23-dependent, PTH-dependent, and FGF23 or PTH-independent. This distinction is mainly helpful diagnostically, since $\mathrm{P}_{\mathrm{i}}$ absorption and calcium absorption are differentially affected (Table 3 ).

Table 3. Human Genetic Disorders of $\mathrm{P}_{\mathrm{i}}$ Homeostasis ${ }^{1}$.

\begin{tabular}{|c|c|c|c|c|c|}
\hline Disorder & Abbreviation & Inheritance & Gene & Mechanism & Ref. \\
\hline \multicolumn{6}{|l|}{ Hyperphosphatemic Disorders } \\
\hline $\begin{array}{l}\text { Hyperphosphatemic Familial } \\
\text { Tumoral Calcinosis type } 1 \text { and the } \\
\text { allelic variant } \\
\text { Hyperostosis-Hyperphosphatemia } \\
\text { Syndrome }\end{array}$ & $\begin{array}{l}\text { HFTC1 } \\
\text { HSS }\end{array}$ & $\begin{array}{l}\mathrm{AR} \\
\mathrm{AR}\end{array}$ & GALNT3 & FGF23 deficiency & {$[156,157]$} \\
\hline $\begin{array}{l}\text { Hyperphosphatemic Familial } \\
\text { Tumoral Calcinosis Type } 2\end{array}$ & HFTC2 & $\mathrm{AR}$ & $F G F 23$ & FGF23 deficiency & {$[158,159]$} \\
\hline
\end{tabular}


Table 3. Cont.

\begin{tabular}{|c|c|c|c|c|c|}
\hline Disorder & Abbreviation & Inheritance & Gene & Mechanism & Ref. \\
\hline $\begin{array}{l}\text { Hyperphosphatemic Familial } \\
\text { Tumoral Calcinosis Type } 3\end{array}$ & HFTC3 & $\mathrm{AR}$ & $K L$ & FGF23 resistance & [160] \\
\hline $\begin{array}{l}\text { Idiopathic Hyperphosphatasia } \\
\text { (Juvenile Paget's Disease) }\end{array}$ & N/A & $\mathrm{AR}$ & TNFRSF11B & OPG deficiency & [161] \\
\hline Pseudohypoparathyroidism & $\begin{array}{l}\text { PHP1A } \\
\text { PHP1B }\end{array}$ & $\begin{array}{l}\mathrm{AD} \\
\mathrm{AD} \text { (impr.) }\end{array}$ & $\begin{array}{l}\text { GNAS } \\
\text { GNAS or } \\
\text { up-stream } \\
\text { regulatory } \\
\text { region }\end{array}$ & $\begin{array}{l}\text { PTH resistance, } \\
\text { FGF23-independent }\end{array}$ & {$[162,163]$} \\
\hline $\begin{array}{l}\text { Familial Isolated } \\
\text { Hypoparathyroidism }\end{array}$ & FIH & $\mathrm{AD}$ or $\mathrm{AR}$ & $\begin{array}{l}\text { CASR } \\
\text { GCMB } \\
\text { PTH }\end{array}$ & $\begin{array}{l}\text { PTH deficiency, } \\
\text { FGF23-independent }\end{array}$ & [164-166] \\
\hline Blomstrand disease & BOCD & $\mathrm{AR}$ & PTHR1 & $\begin{array}{l}\text { PTH resistance, } \\
\text { FGF23-independent }\end{array}$ & {$[167,168]$} \\
\hline \multicolumn{6}{|l|}{ Hypophosphatemic Disorders } \\
\hline X-linked hypophosphatemia & $\mathrm{XLH}$ & X-linked & PHEX & FGF23-dependent & [169] \\
\hline $\begin{array}{l}\text { Autosomal Dominant } \\
\text { Hypophosphatemic Rickets }\end{array}$ & ADHR & $\mathrm{AD}$ & FGF23 & FGF23-dependent & [170] \\
\hline $\begin{array}{l}\text { Autosomal Dominant } \\
\text { Hypophosphatemic Rickets }\end{array}$ & ADHR & $\mathrm{AD}$ & $K L$ & FGF23-dependent & [171] \\
\hline $\begin{array}{l}\text { Autosomal Recessive } \\
\text { Hypophosphatemic Rickets types 1, 2, } \\
\text { and } 3\end{array}$ & $\begin{array}{l}\text { ARHR1 } \\
\text { ARHR2 } \\
\text { ARHR3 }\end{array}$ & AR & $\begin{array}{l}D M P 1 \\
\text { ENPP1 } \\
\text { FAM20C }\end{array}$ & FGF23-dependent & [172-174] \\
\hline $\begin{array}{l}\text { Hereditary Hypophosphatemic } \\
\text { Rickets with Hypercalciuria }\end{array}$ & HHRH & $\mathrm{AR}$ & $S L C 34 A 3$ & $\begin{array}{l}\text { Proximal tubular } P_{i} \text { wasting, } \\
\text { FGF23-independent }\end{array}$ & {$[175,176]$} \\
\hline Vitamin D-resistant rickets type $1 \mathrm{~A}$ & VDDR1A & $\mathrm{AR}$ & CYP27B1 & $\begin{array}{l}1,25(\mathrm{OH})_{2} \mathrm{D} \text { deficiency, } \\
\text { FGF23-independent }\end{array}$ & {$[154,177]$} \\
\hline $\begin{array}{l}\text { Hereditary } 1,25(\mathrm{OH})_{2} \text { D-resistant } \\
\text { rickets }\end{array}$ & HVDDR & $\mathrm{AR}$ & $V D R$ & $\begin{array}{l}1,25(\mathrm{OH})_{2} \mathrm{D} \text { resistance, } \\
\text { FGF23-independent }\end{array}$ & {$[153,178]$} \\
\hline $\begin{array}{l}\text { Familial hypocalciuric } \\
\text { hypercalcemia/neonatal severe } \\
\text { hyperparathyroidism }\end{array}$ & $\begin{array}{l}\text { FHH } \\
\text { NSHPT }\end{array}$ & $\mathrm{AD} / \mathrm{AR}$ & CASR & $\begin{array}{l}\text { PTH excess, } \\
\text { FGF23-independent }\end{array}$ & [179] \\
\hline Jansen disease & & $\mathrm{AD}$ & PTHR1 & $\begin{array}{l}\text { Const. active PTHR1, } \\
\text { FGF23-dependent }\end{array}$ & {$[180,181]$} \\
\hline \multicolumn{6}{|l|}{ Normophosphatemic disorders } \\
\hline Pulmonary alveolar microlithiasis & PAM & $\mathrm{AR}$ & SLC $34 A 2$ & $\begin{array}{l}\text { Reduced alveolar epithelial } P_{i} \\
\text { uptake }\end{array}$ & [35] \\
\hline $\begin{array}{l}\text { Normophosphatemic familial tumoral } \\
\text { calcinosis }\end{array}$ & NFTC & $\mathrm{AR}$ & SAMD9 & Unknown & [182] \\
\hline $\begin{array}{l}\text { Muscle dystrophy and } \\
\text { cardiomyopathy }\end{array}$ & MDC & $\mathrm{AR}$ & $S L C 25 A 3$ & $\begin{array}{l}\text { Reduced mitochondrial } \mathrm{P}_{\mathrm{i}} \\
\text { uptake }\end{array}$ & {$[183,184]$} \\
\hline $\begin{array}{l}\text { Primary familial basal ganglial } \\
\text { calcification type } 1\end{array}$ & $\begin{array}{l}\text { PFBC1 or } \\
\text { IBGC1 }\end{array}$ & $\mathrm{AD}$ & PIT2 & Reduced microglial $\mathrm{P}_{\mathrm{i}}$ uptake & [185] \\
\hline $\begin{array}{l}\text { Primary familial basal ganglial } \\
\text { calcification type } 4\end{array}$ & $\begin{array}{l}\text { PFBC4 or } \\
\text { IBGC4 }\end{array}$ & $\mathrm{AD}$ & PDGFRB & Reduced PIT2 expression & [186] \\
\hline $\begin{array}{l}\text { Primary familial basal ganglial } \\
\text { calcification type } 5\end{array}$ & $\begin{array}{l}\text { PFBC5 or } \\
\text { IBGC5 }\end{array}$ & $\mathrm{AD}$ & PDGFB & Reduced PIT2 expression & [186] \\
\hline $\begin{array}{l}\text { Primary familial basal ganglial } \\
\text { calcification type } 6\end{array}$ & $\begin{array}{l}\text { PFBC6 or } \\
\text { IBGC6 }\end{array}$ & $\mathrm{AD}$ & XPR1 & Reduced vascular $\mathrm{P}_{\mathrm{i}}$ export & [187] \\
\hline $\begin{array}{l}\text { Primary familial basal ganglial } \\
\text { calcification type } 7\end{array}$ & $\begin{array}{l}\text { PFBC7 or } \\
\text { IBGC7 }\end{array}$ & $\mathrm{AR}$ & MYORG & $\begin{array}{l}\text { Unclear, astrocyte dysfunction } \\
\text { and possible NVU disruption } \\
\text { may be causative factors. }\end{array}$ & {$[188,189]$} \\
\hline $\begin{array}{l}\text { Primary familial basal ganglial } \\
\text { calcification type } 8\end{array}$ & $\begin{array}{l}\text { PFBC8 or } \\
\text { IBGC8 }\end{array}$ & AR & JAM2 & Reduced JAM2 expression & {$[190,191]$} \\
\hline
\end{tabular}

1 Adapted from [21]. Bold font was used to visually denote the boundaries between hyperphosphatemic, hypophosphatemic and normophosphatemic disorder categories. $\mathrm{AD}$, autosomal dominant. $\mathrm{AR}$, autosomal recessive. GALNT3, polypeptide N-acetylgalactosaminyltransferase 3. FGF23/FGF23, fibroblast growth factor 23. KL, klotho. TNFRSF11B, TNF receptor superfamily member 11B. GNAS, guanine nucleotide- binding protein, alpha stimulating. CASR, calcium-sensing receptor. GCMB, glial cell missing gene. PTH/PTH, parathyroid hormone. PTHR1/PTHR1, parathyroid hormone 1 receptor. $P H E X$, phosphate-regulating endopeptidase homolog, $\mathrm{X}$-linked. DMP1, dentin matrix acidic phosphoprotein 1. ENPP1, ectonucleotide pyrophosphatase-phosphodiesterase family member 1. FAM20C, golgi-associated secretory pathway kinase. SLC34A3, solute carrier family 34 member 3. CYP27B1, vitamin D 1- $\alpha$ hydroxylase. $V D R$, vitamin D receptor. SLC34A2, solute carrier family 34 member 2. SAMD9, sterile alpha motif domain containing 9. SLC25A3, solute carrier family 25 member 3. PIT2/PIT2, type III sodium-dependent phosphate transporter 2. PDGFRB, platelet derived growth factor receptor beta. PDGFB, platelet derived growth factor subunit B. XPR1, xenotropic and polytropic retrovirus receptor 1. MYORG, myogenesis regulating glycosidase. JAM2/JAM2, junctional adhesion molecule 2. OPG, osteoprotegerin. $\mathrm{P}_{\mathrm{i}}$, inorganic phosphate. $1,25(\mathrm{OH})_{2} \mathrm{D}, 1,25$-dihydroxyvitamin $\mathrm{D}$. NVU, neurovascular unit. 


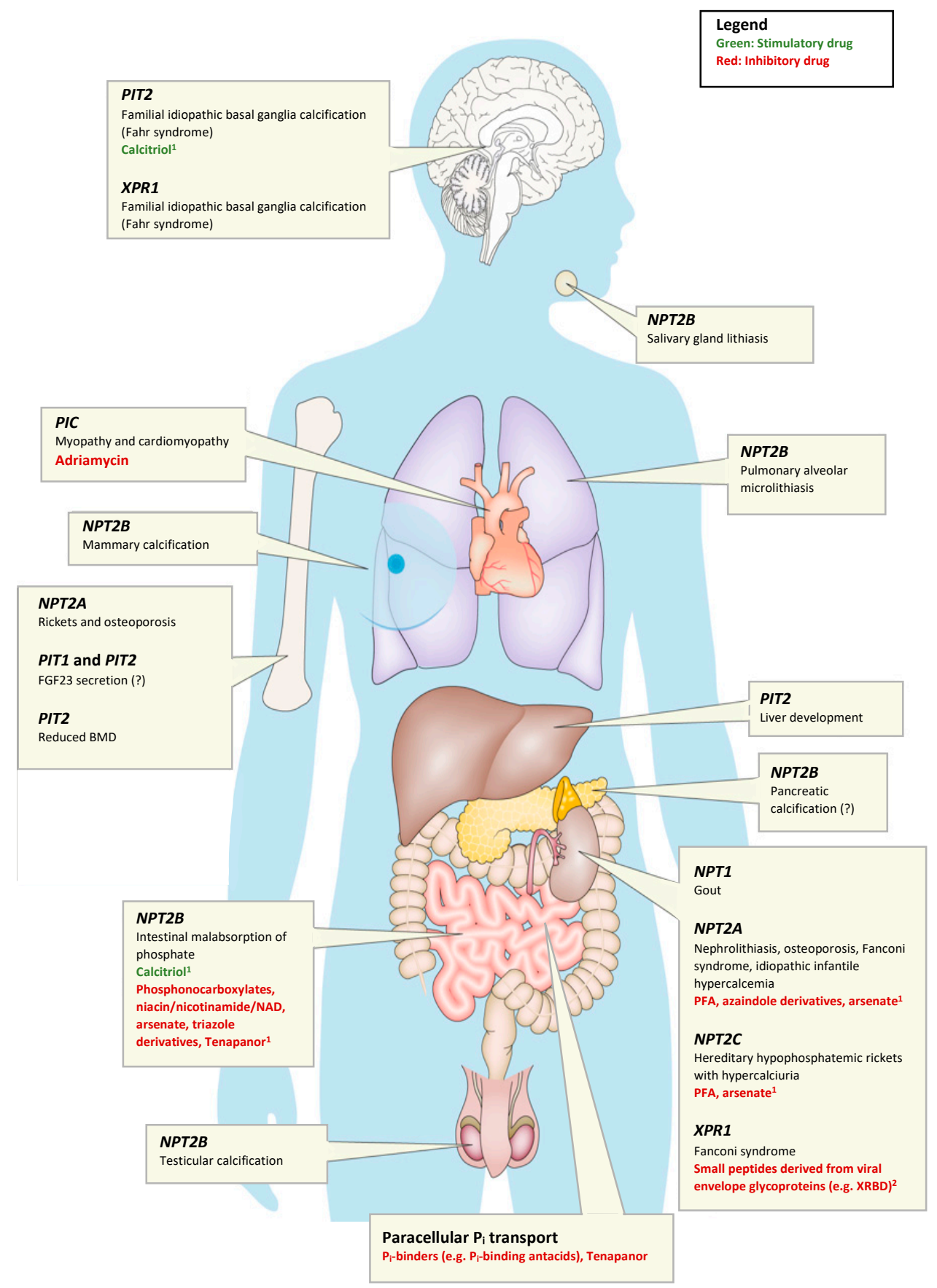

Figure 2. Human disorders of phosphate homeostasis caused by transporters of inorganic phosphate $\left(P_{i}\right)$. Compounds that inhibit $P_{i}$ transport are denoted in red, while compounds that stimulate $P_{i}$ transport are denoted in green. ${ }^{1}$ These compounds may affect their respective $P_{i}$ transporters in tissues other than the ones that the compounds are listed under. For example, NPT2A inhibitors may also affect $P_{i}$ transport in the bone. Additionally, tenapanor is not a direct inhibitor of $P_{i}$ transport through NPT2B. ${ }^{2}$ XPR1 small peptide inhibitors were only reported in in vitro studies. Question mark indicates unknown. FGF23, fibroblast growth factor 23. BMD, bone mineral density. NAD, nicotinamide adenine dinucleotide. NPT1, sodium-dependent phosphate transport protein 1 . NPT2A, sodium-dependent phosphate transport protein $2 \mathrm{~A}$. NPT2B, sodium-dependent phosphate transport protein $2 \mathrm{~B}$. NPT2C, sodium-dependent phosphate transport protein 2C. PFA, phosphonoformic acid. PIT1, type III sodium-dependent $P_{i}$ transporter 1. PIT2, type III sodium-dependent $P_{i}$ transporter 2. PIC, (SLC25A3, solute carrier family 25 member 3). XPR1, xenotropic and polytropic retrovirus receptor 1 . XRBD, soluble ligand that can bind XPR1. Adapted from [46]. 


\section{Metabolic Phosphate Sensing}

Before discussing the tissue-specific roles of $P_{i}$, it may be helpful to summarize what is known about metabolic $P_{i}$ sensing. For several excellent reviews as well, see $[48,192,193]$. Recent evidence suggests that the type $3 \mathrm{Na}^{+}$-dependent $P_{i}$ transporters PIT1 and PIT2 have an important role in metabolic $P_{i}$ sensing. Interestingly, PIT1 and PIT2 might sense extracellular $P_{i}$ without requiring its translocation, which is a process that is also referred to as transport-independent $P_{i}$ sensing $[194,195]$. Therefore, these transporters may serve as sensors for extracellular $P_{i}$ in addition to regulating intracellular $P_{i}$ levels. The transport-independent $P_{i}$-sensing process might involve co-receptors: for example, FGFR1 [48] and the CASR [196]. It is also possible that $P_{i}$ directly binds and inhibits the CASR $[196,197]$. Finally, there is recent evidence that intracellular $P_{i}$ stimulates the synthesis of 5-diphosphoinositol 1,2,3,4,6-pentakisphosphate (IP7) or 1,5-bisdiphosphoinositol 1,2,3,4-tetrakisphosphate (IP8), which are molecules that signal cellular $P_{\mathrm{i}}$ sufficiency and stimulate $P_{\mathrm{i}}$ efflux via Xenotropic and polytropic retrovirus receptor 1 (XPR1) [198-201]. Metabolic $P_{i}$ sensing has a role separate from the endocrine $P_{i}$ sensing discussed above, and it is important for maintaining intracellular $\mathrm{P}_{\mathrm{i}}$ concentrations and producing intracellular effects such as gene activation, as is discussed in more detail below.

\subsection{Extracellular Phosphate Sensing}

Extracellular $P_{\mathrm{i}}$ activates the mitogen-activated protein kinases ERK1 and ERK2 (encoded by MAPK1 and MAPK3) in most cell types [202]. This process is evolutionarily conserved between Drosophila melanogaster and humans [202]. ERK1/2 activation is blocked by pharmacological or genetic inhibitors of the type $3 \mathrm{Na}^{+}$-dependent $P_{i}$ transporters [203]. Since multiple type 3 transporters can fulfill this role, it might be intracellular $P_{i}$ that is sensed to activate ERK1 and ERK2.

However, several observations suggest that extracellular $P_{i}$ is sensed in the cell membrane. Using green fluorescent protein-tagged versions of PIT1 and PIT2, these transporters were shown to dimerize in response to $P_{i}$, which in turn activates ERK1/2 (Figure 3) [204]. This activation appears to occur even if amino acid mutations that block $P_{i}$ transport are introduced into PIT1 and PIT2 [194]. However, it is currently unclear which downstream molecules mediate the activation of ERK1/2 when these transporters function as 'transceptors'.

The exposure of murine bone marrow stromal cells (BMSCs), which are cells with osteoblastic potential, to nanohydroxyapatite (nHAp) crystals increases the expression of osteopontin (Opn) and reduces the expression of alkaline phosphatase (Alp) in a dose-dependent manner [205]. These authors further showed that nHAp activates FGFR substrate 2 (FRS2) and ERK1/2 signaling downstream of Pit and Fgfr, and the inhibition of ERK1/2 blocks the regulation of Opn gene expression [206]. Likewise, pharmacologic inhibition of either Pit or Fgfr in BMSCs decreased the expression of Opn and derepressed Alp [206]. Electron microscopic evaluation showed nHAp at the cell surface of BMSCs, suggesting that nHAp signaling occurs without the internalization of nHAp [206]. Co-localization of immunostaining for Pit, Fgfr, and nHAp further confirmed that nHAp may bridge Pit and Fgfrs in the membrane of BMSCs, and this may be important for mediating the biological effect of nHAp (Figure 3) [206].

Additional evidence that FGFR1 functions as a $P_{i}$ sensor was provided in UMR106 rat osteosarcoma cells. Exposure of these cells to high extracellular $P_{i}$ causes the autophosphorylation of FGFR1 at multiple tyrosine residues [207], although it is currently unclear whether $P_{i}$ binds directly to FGFR1. The sequential phosphorylation of six FGFR1 tyrosine residues $(653,583,463,766,585$, and 654) leads to the activation of FGFR1 signaling [208,209], which involves the phosphorylation of FRS2 and ERK1/2, and the gene expression of Early growth response 1 (Egr1), ETS variant 4, and ETS variant 5 (Etv5) $[48,207]$. The expression of EGR1 and ETV5 upregulates the polypeptide $\mathrm{N}$-acetylgalactosaminyltransferase 3 (GALNT3) $[48,207]$, although this upregulation may require other transcription factors [48]. GALNT3 is the enzyme required for O-glycosylation of FGF23 at threonine 178, whereby it stabilizes bioactive iFGF23 [48]. 
Lastly, crystallographic studies showed the binding of $P_{i}$ to the CASR $[196,197]$. The CASR is highly expressed in the parathyroid glands and distal convoluted renal tubules, and it inhibits PTH secretion by the parathyroids and the reabsorption of calcium from the urine upon the binding of calcium [210]. Conversely, $P_{i}$ inhibits CASR in a non-competitive fashion, resulting in the stimulation of PTH secretion by parathyroid cells [197]. It is unclear at the moment whether the CASR also regulates FGF23 secretion and bioactivity.

\subsection{Intracellular Phosphate Sensing}

Upon uptake via NPT2b and PIT1/2, intracellular (IC) $P_{i}$ stimulates the inositol hexakisphosphate kinases 1 and 2 (IP6K1 and -2) and synthesis of the second messenger IP7 from inositol hexakisphosphate (IP6) $[199,200]$. IP7 is further converted into IP8 by diphosphoinositol pentakisphosphate kinases (PPIP5Ks) [201]. The binding of IP7 or IP8 to the SPX domain of XPR1 [198,199] triggers $P_{i}$ efflux from the cell, regulating the IC $P_{i}$ concentration $[200,201]$.

Cells overexpressing PIT2 showed a concomitant efflux in response to the resulting increase of $P_{i}$ uptake, possibly to maintain IC ATP and $P_{i}$ levels [211]. The $P_{i}$ efflux depends on IP7/IP8 signaling, which promotes efflux through XPR1 [211] and is absent in XPR1 KO cells or when IP6Ks are blocked pharmacologically [211]. Thus, IP7/IP8 may be important for intracellular $P_{\mathrm{i}}$ homeostasis controlled by PIT2 and XPR1 [211].

Subcellular compartments might further sequester intracellular $P_{\mathrm{i}}$. The mitochondrial $\mathrm{P}_{\mathrm{i}}$ carrier protein (PIC, encoded by SLC25A3) is part of the multiprotein complex that makes up the mitochondrial permeability transition pore (mPTP) [46]. The mPTP regulates mitochondrial membrane potential and mitochondrial apoptosis [212] and is important for skeletal and cardiac muscle function [213]. PIT1 localizes to the endoplasmic reticulum (ER), where it seems to be involved in regulating the ER stress of growth plate chondrocytes [214]. Finally, large and small conductance chloride channels transport $P_{i}$ into the sarcoplasmic reticulum of rabbit skeletal muscle [215]. However, whether these compartments participate as intracellular sensors for $P_{i}$ is currently unknown.

Since the cellular uptake of $P_{i}$ lowers extracellular $P_{i}$, the sensing of intracellular $P_{i}$ (metabolic $P_{i}$ sensing) is likely independent of extracellular $P_{i}$ sensing (endocrine $P_{i}$ sensing). However, it is possible that endocrine sensing activates intracellular $P_{i}$ sensing pathways in endocrine cells. 


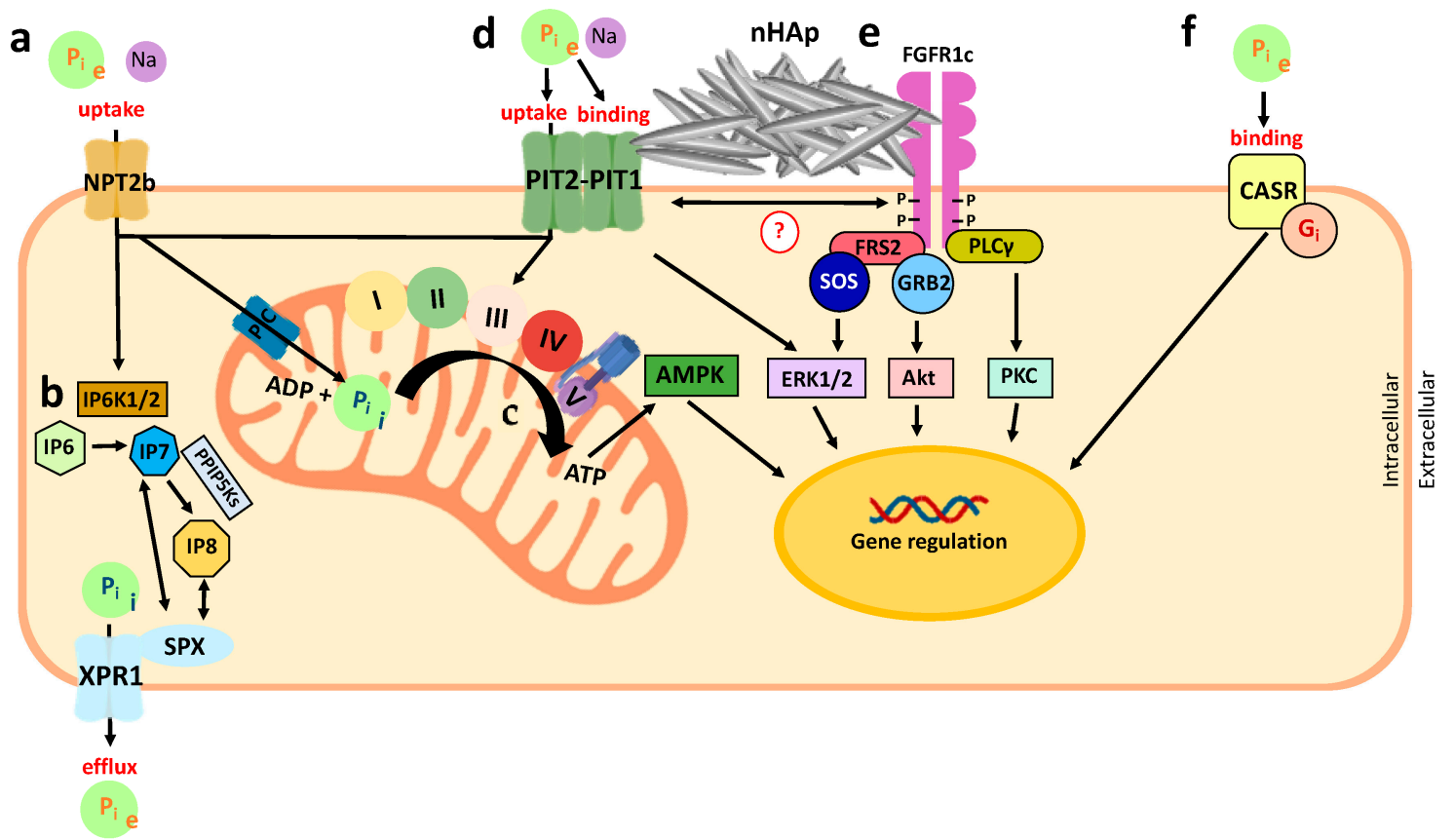

Figure 3. Schematic representation of metabolic $P_{i}$ sensing in mammals (modified from [193]). $P_{i}$ sensing in mammals can be divided into the distinct processes of extracellular $P_{i}\left(P_{i}\right.$ e) sensing and intracellular $P_{i}\left(P_{i}\right.$ i) sensing. (a) Extracellular $P_{i}$ can be imported into the cell by the sodium-dependent phosphate transport protein $2 b(\mathrm{Npt} 2 \mathrm{~b})$, which changes the intracellular $\mathrm{P}_{\mathrm{i}}$ concentration. (b) An increase in intracellular $P_{i}$ stimulates synthesis of 5-diphosphoinositol 1,2,3,4,6-pentakisphosphate (IP7) from inositol hexakisphosphate (IP6) by the inositol hexakisphosphate kinases 1 and -2 [199,200]. IP7 can be further converted into 1,5-bisdiphosphoinositol 1,2,3,4-tetrakisphosphate (IP8) by diphosphoinositol pentakisphosphate kinases [201]. $P_{i}$ efflux through xenotropic and polytropic retrovirus receptor 1 (XPR1) maintains the intracellular $P_{i}$ concentration, and this process is stimulated by the binding of IP7 and IP8 to the SPX domain of this $P_{i}$ exporter [200,201]. (c) In addition to stimulating IP7 and IP8 synthesis, $P_{i}$ can also stimulate ATP flux by serving as a substrate for ATP synthesis at complex $\mathrm{V}$ of the respiratory chain in the mitochondria and by stimulating the respiratory chain directly [216,217]. ATP inhibits the AMP-activated protein kinase (AMPK) pathway, while AMP and ADP activate it $[218,219]$. (d) PIT1 and PIT2, similar to Npt2b, function as $\mathrm{P}_{\mathrm{i}}$ transporters, which raise intracellular $P_{i}$. PIT1 and PIT2 also heterodimerize in response to $P_{i}$ and activate the extracellular signal-regulated kinases 1 and 2 (ERK1/2) pathway transport-independently [204,220]. (e) The binding of nanohydroxyapatite (nHAp) crystals to the cell surface may bridge PIT1 and FGFR1 [206]. FGFR1 activates the AKT, protein kinase C (PKC), and ERK1/2 pathways. (f) In addition to PIT1, PIT2 and FGFR1, the calcium-sensing receptor (CASR) may also function as an extracellular $P_{i}$ sensor, at least in parathyroid cells $[196,197]$. $P_{i}$ acts at arginine residue 62 of the CASR as a non-competitive antagonist $[196,197]$, thereby inhibiting the inhibitory $G$ protein $G_{i}[221]$. Through the actions of AMPK, AKT, PKC, ERK1/2, and G protein, extracellular $P_{\mathrm{i}}$ can regulate gene transcription, such as the expression of osteopontin in bone cells $[18,206,222,223]$ and vascular smooth muscle cells $[224,225]$. $P_{i}$, inorganic phosphate. $P_{i}$ e, extracellular $P_{i} . P_{i} i$, intracellular $P_{i}$. Na, sodium. NPT2b, sodium-dependent phosphate transport protein $2 \mathrm{~b}$. IP6K1/2, inositol hexakisphosphate kinases 1 and -2. IP6, inositol hexakisphosphate. IP7, 5-diphosphoinositol 1,2,3,4,6-pentakisphosphate. IP8, 1,5-bisdiphosphoinositol 1,2,3,4-tetrakisphosphate. XPR1, xenotropic and polytropic retrovirus receptor 1. SPX, a domain of XPR1. PIC, mitochondrial phosphate carrier. ADP, adenosine diphosphate. ATP, adenosine triphosphate. AMPK, adenosine monophosphate-activated protein kinase. PIT1, type III sodium-dependent $P_{i}$ transporter 1 . PIT2, type III sodium-dependent $P_{i}$ transporter 2 . nHAp, nanohydroxyapatite. FGFR1c, fibroblast growth factor receptor 1 isoform c. FRS2, FGFR substrate 2. PLC $\gamma$, phospholipase C gamma isoform. SOS, son of sevenless. GRB2, growth factor receptor bound protein 2. ERK1/2, extracellular signal-regulated kinases 1 and 2. AKT, protein kinase B. PKC, protein kinase C. CASR, calcium-sensing receptor. $\mathrm{G}_{i}$, inhibitory G protein. (I, II, III, IV, V), complexes I-V of the mitochondrial respiratory chain. 


\section{Importance of Dietary Phosphorus for Bone Health}

\subsection{General Importance of Phosphate for Bone Health}

$P_{i}$ is required for proper plate growth and bone development, and along with calcium, it comprises the hydroxyapatite that is deposited during mineralization of the vertebrate skeleton. As a result, $\mathrm{P}_{\mathrm{i}}$ is critical for the mineralization process (particularly during the growth spurt at puberty [226]), to maintain bone strength after the closure of the epiphyses [227], and during fracture repair and remodeling [228]. The process of matrix mineralization requires the secretion of matrix vesicles (MVs) by osteoblasts and hypertrophic chondrocytes $[229,230]$. The phosphatase PHOSPHO1 can liberate $\mathrm{P}_{\mathrm{i}}$ from phosphocholine and other lipids in the MV membrane [21]. $\mathrm{P}_{\mathrm{i}}$ is also thought to be imported into the MVs via PIT1 [21]. MVs induce hydroxyapatite crystal formation [231]. In the presence of sufficient concentrations of extracellular calcium and $\mathrm{P}_{\mathrm{i}}$, these crystals continue to grow after the dissolution of the MV membrane [231]. The ambient extracellular $P_{i}$ concentration in bone is maintained by tissue non-specific alkaline phosphatase (TNAP), which is abundant in MVs [21]. TNAP cleaves pyrophosphate $\left(\mathrm{PP}_{\mathrm{i}}\right)$ and other organic bisphosphonates, which generates two $\mathrm{P}_{\mathrm{i}}$ molecules [21]. A high $\mathrm{P}_{\mathrm{i}} / \mathrm{PP}_{\mathrm{i}}$ ratio is generally thought to favor mineralization [232-234]. Clinically relevant hypophosphatemic individuals exhibit an increased activity of alkaline phosphatase [22,235]. This allows bone-specific alkaline phosphatase activity to serve as a marker of $P_{i}$ homeostasis in the bone [22,235].

Dietary phosphorus deprivation impairs cell metabolism and causes skeletal demineralization to occur. Moreover, secondary changes due to the adaptive hormonal response (i.e., upregulation of calcitriol, suppression of PTH and FGF23) can be observed. The main process that stimulates bone resorption is calcitriol-mediated activation of osteoclasts through the receptor activator of NF- $\mathrm{kB}$ (RANK)-RANK Ligand (RANKL) signaling, as described in more detail below [236,237]. This process is more important with prolonged dietary phosphorus deficiency and can cause rickets and stunted growth in children and osteomalacia in adults [90,91]. In addition, there are several acute effects of phosphorus deprivation, which will be described separately for each tissue below.

Similarly, high dietary phosphorus intake adversely affects bone health. Firstly, high dietary phosphorus can reduce calcium absorption and serum calcium concentrations through the formation of insoluble calcium- $\mathrm{P}_{\mathrm{i}}$ complexes [238]. This reduction in serum calcium causes reduced calcium binding to CASR and thereby reduces the inhibition of CASR [239]. Recently, it was shown that $P_{i}$ can bind and directly inhibit CASR [196,197]. As a result, secondary hyperparathyroidism develops, which in turn stimulates bone resorption $[197,239,240]$. Additionally, $P_{i}$ has direct effects on bone cells: for example, $P_{i}$ stimulates the expression of bone matrix protein osteopontin, which is a mineralization inhibitor [18,222]. Thereby, high dietary phosphorus is associated with increased risk for bone fractures, as shown in a study of 2420 Brazilian individuals in whom every $100 \mathrm{mg}$ of dietary phosphorus intake increased the risk of fracture by $9 \%$ [241]. Recent insights suggest that FGF23 (whose levels are determined by $\mathrm{P}_{\mathrm{i}}$ concentrations) may impair bone matrix mineralization independently of calcium by transcriptionally suppressing TNAP (although this effect also suppresses OPN) [242,243]. High phosphate containing soft drinks may finally affect dental mineralization, as discussed later in this review.

\subsection{Role of Phosphate in Chondrocytes}

Chondrocytes produce and maintain the extracellular matrix of joint cartilage and permit the longitudinal growth of long bones through endochondral ossification. $P_{i}$ is essential for normal hypertrophic differentiation and apoptosis, which was shown in several primary [244-246] and stable chondrocytic cell lines $[247,248]$. Hypertrophic differentiation and apoptosis require the activation of ERK1/2 and the mitochondrial-caspase-9 pathway [244]. These processes are blocked by ablation or pharmacological inhibition of the PIT1 transporter or of the mitogen-activated protein kinase kinase 1 [246,248]. In addition to the ERK pathway, $P_{i}$ induces nitrate or nitrite, which stimulates nitric oxide synthase (NOS) production and, in turn, stimulates chondrocyte apoptosis [248]. Furthermore, 
the acute chondrocyte-specific deletion of Pit 1 in mice results in pronounced cell death in the first two postnatal days, possibly owing to $P_{i}$ transport-independent ER stress [214]. Chondrocytes might also regulate systemic $P_{i}$ homeostasis by secreting FGF23 [244], but it is unknown whether this is under the feedback control of $P_{i}$.

In summary, $\mathrm{P}_{\mathrm{i}}$ stimulates hypertrophic differentiation and apoptosis in chondrocytes via PIT1, ERK1 and ERK2, and possibly via NOS, which is necessary for normal bone growth and possibly articular cartilage function.

\subsection{Role of Phosphate in Osteoblasts and Osteocytes}

In the vertebrate skeleton, osteoblasts and osteocytes are responsible for the synthesis of the bone matrix [249]. The bone matrix is composed of type 1 collagen, non-collagenous proteins (such as osteocalcin) and small integrin-binding ligand, N-linked glycoprotein (SIBLING) proteins [including dentin matrix acidic phosphoprotein 1 (DMP1), matrix extracellular phosphoglycoprotein (MEPE), and OPN] [250]. When osteoblasts become buried in the bone matrix, they undergo terminal differentiation into osteocytes, which serve as mechanosensors and secrete endocrine and paracrine factors to maintain skeletal homeostasis [251]. $P_{i}$ may stimulate osteoblast proliferation and differentiation, as it induces the expression of genes important for cell proliferation, energy metabolism, and mineralization in osteoblast-like cells $[47,252,253]$. Similarly, $P_{i}$ might also stimulate insulin-like growth factor 1 expression in the mouse-derived osteoblast cell line MC3T3-E1, which enhances osteoblast proliferation in an autocrine fashion [223,254]. In MC3T3 cells and primary murine calvaria-derived osteoblasts, $P_{\mathrm{i}}$ induces the expression of Fos-related antigen 1, Opn, and matrix Gla protein (which are genes required for mineralization) [223,255]. This process is dependent on ERK1 and ERK2 [223,255], further supporting the role of $P_{i}$ in mineralization.

$P_{i}$ stimulates osteocyte maturation and matrix formation in the osteocyte lacuna. This process can be modeled in IDG-SW3 osteocyte-like murine cells in vitro, in which $10 \mathrm{mM} \mathrm{P} \mathrm{P}_{\mathrm{i}}$ and $10 \mathrm{nM}$ calcitriol induces the gene expression of Galnt3, Dmp1, phosphate-regulating endopeptidase homolog, X-linked, ectonucleotide pyrophosphatase-phosphodiesterase family member 1, and Mepe [256]. Additionally, $P_{i}$ (and calcitriol and PTH) cause osteocytes to secrete FGF23 to regulate systemic $P_{i}$ homeostasis [257-259].

In summary, $P_{\mathrm{i}}$ stimulates the differentiation of osteoblasts and osteocytes, matrix maturation, and bone formation. These processes involve the function of $P_{i}$ transporters and ERK $1 / 2$ signaling in vitro. The mild bone and mineral metabolism phenotypes of the global Pit1 and Pit 2 null mice suggest a high degree of redundancy of these generally co-expressed transporters $[46,260]$. Bone-specific ablation of Pit1 and Pit2 (individually and in combination) in mice might be required to shed light on their metabolic and endocrine functions.

\subsection{Role of Phosphate in Osteoclasts and Bone Resorption}

Osteoclasts are large, multinucleated cells derived from the monocyte lineage that are responsible for bone resorption [261], which is necessary for the remodeling and repair of the skeleton. Osteoclasts express NPT2A, PIT1, and PIT2 [262]. A concentration of $4 \mathrm{mM}$ extracellular $\mathrm{P}_{\mathrm{i}}$ inhibits osteoclast-like cell formation in mouse bone marrow cells [237]. This extracellular $P_{i}$ concentration similarly decreases the number and area of resorption pits formed by mature rat osteoclasts on sperm whale dentine slices, which is a common assay for osteoclast function [263]. This observation presumably reflects a feedback mechanism to limit the degradation of hydroxyapatite. This feedback mechanism might involve the NPT2A-dependent inhibition of RANK-RANKL signaling, the inhibition of osteoclast growth by $P_{i}$ [236], and the suppression of microRNA 223 expression (which was reported in the pre-osteoclast RAW264.7 cell line [264] and in Npt2a-null mice [265]). $P_{i}$ reduces the gene expression of RANKL in osteoblast lineage cells, which results in the suppression of RANK in osteoclasts and the inhibition of osteoclastogenesis and bone resorption [237]. However, some $P_{i}$ is required for normal osteoclast function. Both WT mice fed a low $P_{\mathrm{i}}$ diet and Hyp mice (a murine model 
of X-linked hypophosphatemic rickets, XLH) exhibited decreased osteoclast numbers in osteoclast-like cells derived from bone marrow cells compared with WT mice fed normal $P_{i}$ diets [266]. This defect was reversed by a high $\mathrm{P}_{\mathrm{i}}$ diet [266]. PFA, an inhibitor of $\mathrm{Na}^{+}-\mathrm{P}_{\mathrm{i}}$ cotransporters, reduces bone resorption in cultured osteoclasts, possibly by inhibiting ATP production (for which uptake of extracellular $P_{i}$ is required) [267]. Additionally, as a result of increased mitochondrial respiration, extracellular $P_{i}$ stimulates the production of reactive oxygen species (ROS), which are signaling factors necessary for osteoclastogenesis and which stimulate bone resorption in RAW264.7 osteoclasts [268]. Furthermore, the generation of ROS increases osteoclast function and survival, which indicates that $P_{i}$ is required for the normal function of osteoclast cells [268].

In summary, osteoclasts express NPT2A, PIT1, and PIT2 transporters. High $P_{i}$ levels limit the survival and differentiation of osteoclasts, which might provide a mechanism of feedback inhibition during bone resorption, which is a process that releases large quantities of $P_{i}$. However, some $P_{i}$ seems to be required for normal osteoclast function.

\section{Importance of Dietary Phosphorus for Teeth (or Dental Health)}

The teeth are comprised of an enamel that is formed by epithelial cells (called amelobasts) and dentin [269] that is formed by mesenchymal cells (called odontoblasts); both tissues surround the dental pulp, which is a soft connective tissue that contains blood vessels and nerve fibers [269]. Cementum, periodontal ligament, and alveolar bone connect the teeth to the jaw [269]. Similar to the bone, hydroxyapatite is a major component of enamel and dentin. Different from the hydroxyapatite in the skeleton, in teeth, it is fluorinated, contains metal cation substitutions for calcium, and carbonate substitutions for $\mathrm{P}_{\mathrm{i}}$ [270]. Fluorapatite (FAP, $\left[\mathrm{Ca}_{10}\left(\mathrm{PO}_{4}\right)_{6} \mathrm{~F}_{2}\right]$ ) is less soluble than hydroxyapatite [270], which explains why fluoride is an effective agent to improve dental health (though only within a narrow window of 3-4 mg for adults, whereas excessive levels lead to dental fluorosis) [270,271].

Adequate nutritional quantities of calcium and phosphorus are important for dental mineralization. A dietary ratio of $4-5$ was necessary for normal bone and dentin calcification in rats that were observed from 23 to 70 days of age [272,273]. Calcium and phosphorus deficiency disturb calcification of the growing dentin and alveolar bone in rats [272,274], although enamel formation and calcification are not impaired [272]. In young rats, dietary phosphorus deficiency in the absence of vitamin D reduces overall incisor tooth mass [273,275], which is not observed in adult rats [273]. Moreover, histomorphometric evaluation shows increased levels of alveolar bone resorption in response to calcium and phosphorus deficiency [274,276].

Excessive phosphorus intake, on the other hand, also produces an inappropriate $\mathrm{Ca} / \mathrm{P}$ ratio, and it was shown in degus (Octodon degu) to increase amelogenesis and dentinogenesis [277]. The results were a thicker enamel layer, the formation of enamel pearls, and altered dentin structure [277]. The authors also observed enamel depigmentation and hypoplasia, as well as a loss of the superficial enamel layer and a pitted appearance of the enamel layer [277]. This effect on enamel formation might occur during the secretory stage [277]. Moreover, a 1.3-fold increase in dental decay was observed in children consuming diet sodas, which can contain high concentrations of $P_{i}$ [278]. Additionally, high phosphorus exposure infamously led to osteonecrosis of the jaw (a condition commonly known as "phossy jaw") in 19th-century matchmakers [279]. Specifically, these workers developed gingivitis and sequestration of the alveolar crest bone, and they experienced osteonecrosis of the mandibular and maxillary bones [279]. Though "phossy jaw" is not a clinical issue in the present, there is concern that "bisphossy jaw" may be its modern-day equivalent. Oral bisphosphonates often treat disorders such as osteoporosis, but these medications carry a concerning side effect of maxillary and mandibular bone necrosis and sequestration [280]. However, the mechanism through which oral bisphosphonates cause osteonecrosis is unknown [279]. 
Role of Phosphate in the Tooth

Among the currently known $\mathrm{P}_{\mathrm{i}}$ transporters (Slc34a1, Slc34a2, Slc34a3, Slc20a1, Slc20a2, and Xpr1), SLC20A2/PIT2 is the most highly expressed in teeth [281]. However, knockout mouse models showed that no single transporter is essential for initiation of the mineralization process [281]. PIT1 is expressed in ameloblasts and odontoblasts, while PIT2 is expressed in the subodontoblastic cell layer and the stratum intermedium of ameloblasts [281,282]. PIT2 appears to be involved during the mineralization of dentin, as suggested by the dentin dysplasia described in the global Pit2 knockout [281]. Slc34a1/Npt2a and Slc34a2/Npt2b are expressed in the MRPC-1 rat odontoblast-like mineralizing pulpal cell line $[283,284]$. Slc34a2/Npt2b is negligibly expressed in ameloblasts during the secretory stage, but it is significantly upregulated in the maturation stage [281,284,285]. However, the role of Npt2b in tooth development and mineralization is unknown [284].

Individuals with XLH (a hypophosphatemic condition characterized by FGF23 overproduction [72]) exhibit various dental abnormalities. These abnormalities include the abnormal mineralization of dentin and increased pulp chambers (resulting in dental fractures), less abundant cementum (resulting in impaired tooth attachment), and an increased risk of periodontal disease and the development of dental abscesses [21,286,287]. Enamel is largely unaffected in XLH [288]. Whether these changes are caused by hypophosphatemia alone or in conjunction with FGF23 excess remains to be shown.

\section{Importance of Dietary Phosphorus for Cardiovascular Health}

\subsection{Role of Phosphate in Cardiac Muscle Function}

Hypophosphatemia causes skeletal and cardiac myopathy by reducing intramuscular ATP synthesis and decreasing 2,3-bisphosphoglycerate (2,3-BPG) in erythrocytes (which reduces skeletal muscle oxygenation) $[216,217,289,290]$. Additionally, ventricular arrhythmia can occur in the context of acute myocardial infarction [291]. These hypophosphatemic effects are largely reversible but can lead to rhabdomyolysis, heart failure, and death in some cases [92,93,289,292-295].

On the other hand, hyperphosphatemia is associated with myocardial hypertrophy in rats [296] and humans with CKD [297-299]. High serum $P_{i}$ is also associated with increased cardiovascular morbidity and mortality in these patients [299,300]. Finally, hyperphosphatemia can often cause vascular calcification in CKD, and the extent and histoanatomic type of calcification predict subsequent mortality [301,302].

These effects are thought to be mediated by FGF23, which causes endothelial dysfunction and increases arterial stiffness [303], activates the renin-angiotensin system [304], and causes inflammation [305], vascular calcification [306], and left ventricular hypertrophy (LVH) [307,308]. For an in-depth examination of the link between FGF23 and cardiovascular disease, see the excellent review by Stohr et al. [308]. Additionally, secondary hyperparathyroidism is associated with heart failure [309], hypertension [310], LVH [311,312], arrhythmias [312], and calcific valvular disease [311,312].

\subsection{Role of Phosphate in Vascular Health}

Hyperphosphatemia causes vascular smooth muscle cell (VSMC) apoptosis, osteogenic transdifferentiation, and vascular calcification [313-315]. VSMC apoptosis requires the downregulation of growth-arrest specific gene 6 and its receptor, Axl [316]. This downregulation reduces phosphatidylinositol 3-kinase-mediated phosphorylation of protein kinase B, which is also known as AKT [316]. As a result, $\mathrm{Bcl} 2$ (an anti-apoptotic protein) is inactivated, and Bad (a pro-apoptotic mediator) and caspase 3 are activated [316]. The osteogenic transdifferentiation of VSMCs and vascular calcification require PIT1 and PIT2 and the activation of ERK1/2 in a transport-independent manner [224,225,317]. Additionally, the activation of WNT- $\beta$-catenin-runt-related transcription factor 2 signaling (an anabolic signaling pathway important for the function of osteoblasts and osteocytes) by $\mathrm{P}_{\mathrm{i}}$ can be observed [46,318-321]. Conversely, transdifferentiation is inhibited by secreted frizzled-related protein 5 [46,322]. PIT2 also mediates $P_{i}$ uptake into the microglia, which inhibits vascular calcification in the basal ganglia in an 
interplay with the $P_{i}$ exporter XPR1 [187,323]. Additional sodium-independent transport systems for the intake and efflux of $P_{i}$ may exist in VSMCs, which have not been well-characterized [198,324,325].

High dietary phosphorus finally reduces endothelium-dependent vasodilation in vitro and was shown to reduce flow-mediated vasodilation in healthy men [326]. In a study of normal U.S. adults, Kendrick et al. showed that high-normal levels of serum $P_{i}$ are associated with a high ankle-brachial pressure index, which is a marker for arterial stiffness [327]. Thereby, high dietary phosphorus may acutely increase the risk of cardiovascular mortality [326].

\subsection{Role of Phosphate in Erythrocyte Function}

$P_{i}$ affects erythrocyte function directly $[289,290]$ and indirectly via FGF23 [328]. Hypophosphatemia reduces the concentration of 2,3-BPG in erythrocytes, since $P_{i}$ is required for the synthesis of ATP and thus for the glycolytic synthesis of the 2,3-BPG precursor, 1,3-bisphosphoglycerate [290]. For example, Lichtman et al. found a 45\% reduction of 2,3-BPG in the erythrocytes of patients with parenteral nutrition-induced hypophosphatemia [290]. Reduced concentrations of 2,3-BPG shift the oxyhemoglobin dissociation curve to the left (increasing hemoglobin affinity for $\mathrm{O}_{2}$ ), and thereby hypophosphatemia can cause tissue hypoxia [289].

Blood $P_{\mathrm{i}}$ may indirectly affect hematopoesis by regulating FGF23. FGF23 may stimulate hematopoiesis, as suggested by low erythrocyte counts found in FGF23 null mice [329]. In turn, erythropoietin may stimulate the synthesis and secretion of FGF23 by myeloid lineage LSK cells in the hematopoietic bone marrow [330].

\section{Importance of Dietary Phosphorus for Skeletal Muscle Health}

Similar to cardiac muscle, $\mathrm{P}_{\mathrm{i}}$ is essential in skeletal muscle as a substrate for ATP and CrP synthesis [331,332]. Hypophosphatemia causes a reduction in ATP flux $\left(\mathrm{V}_{\mathrm{ATP}}\right)$ in mouse models [217]. Similarly, the ablation of Pit1 and Pit2 in mice is post-natally lethal due to a generalized skeletal muscle myopathy [333]. Likewise, patients with hypophosphatemia develop myopathy in addition to rickets and osteomalacia [332]. Moreover, iatrogenic $P_{i}$ depletion in patients with chronic renal failure results in proximal myopathy [8], and rhabdomyolysis can occur with severe hypophosphatemia superimposed on simple phosphorus deficiency [92,292,334].

On the other hand, hyperphosphatemia may contribute to the development of muscle weakness and frailty, at least in patients with CKD $[335,336]$. High-medium $P_{i}$ concentrations cause protein loss in myotubes from rat L6 cells and stimulate autophagy, resulting in myotube atrophy [337].

\section{Role of Phosphate in Skeletal Muscle}

We recently showed that hypophosphatemia causes a reduction in $\mathrm{V}_{\mathrm{ATP}}$, as shown by a $50 \%$ reduction in WT mice fed a low $P_{i}$ diet [217]. $V_{\text {ATP }}$ in these mice normalized after intravenous $P_{i}$ supplementation [217]. Likewise, the simultaneous conditional deletion of all four Pit1/2 alleles in mouse skeletal muscle causes muscular atrophy and myofiber degeneration by post-natal day 10 (P10) [333]. These mice die by P13 [333]. Similarly, the ablation of three of four Pit1/2 alleles in skeletal muscle reduced the running ability of these mice as measured by wheel turns/day [333]. This result suggested that the loss of Pit1/2 causes impaired muscle function [333]. Studies in C2C12 myocyte cultures suggest that $P_{i}$ acts at complex $V$ of the respiratory chain as a substrate for ATP synthesis during oxidative phosphorylation $[216,217]$.

Little is known so far about the molecular mechanism, but $P_{i}$ appears to maintain cytochrome b oxidation and cytochrome c reduction [338] and to stimulate the activity of several Krebs cycle dehydrogenases: 2-oxoglutarate dehydrogenase, isocitrate dehydrogenase, and malate dehydrogenase [339-342]. This action of $P_{i}$ increases the concentrations of mitochondrial electron donors (FADH, NADH, and NADPH) to fuel the electron transport chain. Additionally, $\mathrm{P}_{\mathrm{i}}$ is an important cofactor for glyceraldehyde 3-phosphate dehydrogenase, an important rate-limiting glycolytic enzyme that generates NADH [343,344]. 
The type III Na ${ }^{+} / P_{\mathrm{i}}$ cotransporters PIT1 and PIT2 mediate $\mathrm{P}_{\mathrm{i}}$ uptake into the sarcoplasma [345-348], and it is then transported into the mitochondria by PIC [21] and the mitochondrial dicarboxylate carrier [349,350]. PIC is also a component of the mPTP, which regulates calcium transport into the mitochondrial matrix [213]. Human LOF mutations of SLC25A3 [183,184,213,351] or cardiac-specific deletion in mice [352] cause cardiomyopathy.

However, the mechanism whereby blood $\mathrm{P}_{\mathrm{i}}$, PIT1, and PIT2 modify muscle ATP synthesis is not clear, since the hydrolysis of ATP and CrP during exercise may generate sufficient $P_{i}$ inside myofibers for ATP synthesis. In fact, the sarcoplasmic buildup of $P_{i}$ may be an important cause of muscle fatigue [353]. Sarcoplasmic $P_{i}$ can increase from 5-30 mM following intense exercise, which has been shown to reduce peak force by decreasing force per actin-myosin bridge, by increasing the number of low-force bridges in skeletal muscle, by decreasing cytosolic ionized calcium, and by causing calcium- $P_{i}$ precipitations in the sarcoplasmic reticulum [46,353-357].

Since the activation of the ERK1/2 pathway $[194,204]$ is necessary for normal neuromuscular junctions [358,359], therefore, an intriguing possibility is that the transport-independent signaling functions of PIT1/2 are important for skeletal muscle function $[204,333]$.

In summary, $P_{i}$ is required to maintain muscle function, but excess $P_{i}$ leads to calcification (which is best documented in vascular smooth musculature) and skeletal muscle fatigue. This process may involve the functions of the PIT1/2 transporters and of ERK1/2 signaling.

\section{Importance of Dietary Phosphorus for Healthy Aging}

As examined in the previous chapters of this review, concentrations of $P_{i}$ that are either too high or too low both have detrimental health effects. Since $P_{i}$ depletion in terrestrial animals and humans is rare due to the ubiquitous nature of phosphorus in the diet (particularly in processed foods [96] and when used in high doses to treat hypophosphatemic disorders [360]), we will focus our discussion of longevity on the effects of high dietary phosphorus.

\subsection{High Dietary Phosphate Reduces Longevity in Lower Species}

We previously used Drosophila melanogaster to study the effects of high dietary $\mathrm{P}_{\mathrm{i}}$ on longevity. Supplementation of standard medium (SM) with $30 \mathrm{mM} \mathrm{P}_{\mathrm{i}}$ reduced fly lifespan to $38 \pm 2.4$ days [361]. In contrast, control $y w$ flies had a median lifespan of $42 \pm 0.8$ days, and flies cultured in $\mathrm{SM}+30 \mathrm{mM}$ sodium sulfate had a median lifespan of $44 \pm 0.8$ days [361]. Median lifespan increased to $49 \pm 1.9$ days and $47 \pm 1.8$ days, respectively, by inhibiting $P_{\mathrm{i}}$ intake through the addition of either sevelamer (which blocks $P_{i}$ absorption) or PFA (which inhibits the cellular uptake of $P_{i}$ ) to the SM [361]. Finally, more recent findings show that PFA and the ablation of MFS2 (a $P_{i}$ transporter in fly Malphigian tubules that functions in $\mathrm{P}_{\mathrm{i}}$ excretion) increase blood $\mathrm{P}_{\mathrm{i}}$, decrease the formation of Malphigian tubule calcium- $P_{i}$ stones, and increase lifespan in Drosophila [362]. These results suggest that the excretion of $P_{i}$ and the formation of Malpighian tubule stones reduce the longevity of flies cultured on a high $P_{i}$ medium [362].

\subsection{High Dietary Phosphorus Reduces Longevity in Higher Species and Humans}

Similarly, in higher species such as mice, high dietary phosphorus negatively affects longevity. $P_{i}$ loading in uremic rats dose-dependently induces inflammation in the aorta, heart, and kidneys [363]. Furthermore, Klotho null mice have severe hyperphosphatemia $[364,365]$. These mice die prematurely due to vascular and renal calcification, as well as atrophy of the skin, muscle, intestinal, and gonadal tissues [364,365].

The aging-like syndrome of $\mathrm{Klotho}^{-/-}$mice is ameliorated when serum $\mathrm{P}_{\mathrm{i}}$ levels are normalized in $\mathrm{Npt} 2 \mathrm{a}^{-/}$and $\mathrm{Klotho}^{-/}$double-knockout mice, and it is induced again by placing these double-knockout

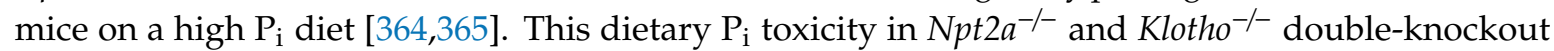
mice very much resembles the potential of dietary $P_{i}$ to modify mortality in CKD patients, as discussed above $[363,366-368]$. 
In addition, $P_{i}$ has recently been implicated in cancer aggressiveness [369]. SLC20A1 may be overexpressed in tongue tumors [370,371], and Npt2b expression is increased in lung cancers [369,371]. Furthermore, high dietary $P_{i}$ stimulates the AKT-mammalian target of rapamycin regulatory pathway, leading to higher lung cancer aggressiveness in K-ras ${ }^{\mathrm{LA} 1}$ mice $[369,371]$. The knockdown of Npt2b with siRNA was shown to decrease the number and size of lung tumors in this mouse model, suggesting that the regulation of $P_{i}$ consumption through NPT2b knockdown may be a possible treatment for lung cancer [371,372]. Similarly, a high $P_{i}$ concentration in the tumor microenvironment has been identified as a marker for tumor progression in mouse mammary gland tumors [371,373]. For a more detailed overview of the role of $\mathrm{P}_{\mathrm{i}}$ transporters in cancer and tumor biology, refer to the excellent review by Lacerda-Abreu et al. [371].

Finally, high dietary phosphorus increases fracture risk [241], which has implications for lifespan, since excess mortality for five years following a proximal non-hip or lower leg fragility fracture, and $\geq 10$ years following a hip fracture, have been reported [374]. These results together further support a role for excess phosphorus in reducing longevity, even in humans who have normal kidney function.

\section{Conclusions}

Phosphorus is an important nutrient in our diet. $P_{i}$ serves crucial functions as an important physiologic buffer, as a substrate for critical cellular functions, and along with calcium as a component of the bone mineral in the skeleton. $P_{i}$ is absorbed in the small intestine via a paracellular route of passive diffusion or a transcellular route via $P_{i}$ transporters such as NPT2b. Interruption of these absorption processes can result in hypophosphatemia. Since phosphorus has become abundant in Western diets-where it often supplements prepared foods-it is also important to consider that excess levels of dietary phosphorus have adverse health effects. High dietary phosphorus has been implicated in several processes related to accelerated aging: for instance, increased fracture risks, cancer proliferation, cardiac and skeletal muscle dysfunction, and vascular calcification. Currently, it is estimated that dietary phosphorus exceeds the RDA by $1.5-2 \mathrm{X}$, which is of particular concern for individuals with cardiovascular diseases or CKD. A better declaration and regulation of $P_{i}$ additives in the processed foods industries, and more clinical research, is clearly needed to understand how to optimize nutritional phosphorus best while avoiding toxic side effects. Of particular interest for the latter are agents that target NPT2b to block intestinal $P_{i}$ absorption, agents that regulate PIT1/2 (and possibly IP7/IP8/XPR1) to optimize cellular $P_{i}$ homeostasis, and agents that improve renal $P_{i}$ excretion via NPT2a and NPT2c. Furthermore, the contributions of type I (SLC17) and type III (SLC20) $P_{i}$ transporters, and the molecular basis for paracellular diffusion in the intestine and proximal renal tubules, are still largely unknown. Thus, research into these pathways could provide novel targets for the development of therapeutics that improve the outcomes of individuals with cardiovascular diseases or CKD.

\section{Key Points}

Phosphorus is abundant in Western diets, and understanding endocrine and metabolic $P_{i}$ sensing is essential to understand human disorders. Both high and low dietary phosphorus can cause adverse health effects and impair longevity, and it may be important to consider implementing phosphorus analysis as a routine measurement in clinical practice. Declaration of $P_{i}$ additive use by the food industry may be helpful, since currently dietary phosphorus intake routinely exceeds the RDA.

Author Contributions: J.S., and C.B. wrote the manuscript. All authors have read and agreed to the published version of the manuscript.

Funding: We are grateful to Yale University for providing summer internship funding for J.S. The funders had no role in the design of the study; in the collection, analyses, or interpretation of data; in the writing of the manuscript, or in the decision to publish the results. 
Acknowledgments: We thank Ardy van Helvoort, NUTRIM; School of Nutrition and Translational Research in Metabolism, Maastricht University, Maastricht, The Netherlands, for his insights and helpful comments to this review.

Conflicts of Interest: Juan Serna declares that he has no conflict of interest. Clemens Bergwitz has received research support from Nutricia North America, Bethesda, MD, USA, for an unrelated project. He serves on the advisory board for Bayer AG, Berlin, Germany.

\section{Glossary}

\begin{tabular}{|c|c|}
\hline Key Term/Abbreviation & Definition \\
\hline (I, II, III, IV, V) & Complexes I-V of the mitochondrial respiratory chain \\
\hline 1,25-dihydroxyvitamin D & $1,25(\mathrm{OH})_{2} \mathrm{D}$ \\
\hline $2^{\prime}-\mathrm{PP}$ & 2'-Phosphophloretin \\
\hline 2,3-BPG & 2,3-Bisphosphoglycerate \\
\hline $\mathrm{AD}$ & Autosomal dominant \\
\hline $\mathrm{AKT}$ & Protein kinase B \\
\hline Alp & Alkaline phosphatase \\
\hline AMP & Adenosine monophosphate \\
\hline AMPK & AMP-activated protein kinase \\
\hline AR & Autosomal recessive \\
\hline ATP & Adenosine triphosphate \\
\hline BBMV & Brush border membrane vesicle \\
\hline BPG & Bisphosphoglycerate \\
\hline CASR & Calcium-sensing receptor \\
\hline CKD & Chronic kidney disease \\
\hline c-myb & V-myb avian myeloblastosis viral oncogene homolog \\
\hline $\mathrm{CrP}$ & Creatine phosphate \\
\hline CYP24A1 & The vitamin D 24-hydroxylase \\
\hline CYP27B1 & The vitamin D 1- $\alpha$ hydroxylase \\
\hline DMP1 & Dentin matrix acidic phosphoprotein 1 \\
\hline DNA & Deoxyribonucleic acid \\
\hline EGF & Epidermal growth factor \\
\hline EGR1 & Early growth response 1 \\
\hline Enpp1 & Ectonucleotide pyrophosphatase-phosphodiesterase family member 1 \\
\hline ER & Endoplasmic reticulum \\
\hline ERK1 & Extracellular signal-regulated kinase 1 \\
\hline ERK2 & Extracellular signal-regulated kinase 2 \\
\hline Etv5 & ETS variant 5 \\
\hline FADH & Flavin adenine dinucleotide \\
\hline FAM20c & Golgi-associated secretory pathway kinase \\
\hline FAP & Fluorapatite mineral \\
\hline FGF & Fibroblast growth factor \\
\hline FGF23 & Fibroblast growth factor 23 \\
\hline FGFR1 & Fibroblast growth factor receptor 1 \\
\hline FGFR1c & FGFR1 isoform c \\
\hline FRS2 & FGFR substrate 2 \\
\hline \multirow{2}{*}{ GALNT3 } & Polypeptide \\
\hline & N-Acetylgalactosaminyltransferase 3 \\
\hline GC & Glucocorticoid \\
\hline GCMB & Glial cell missing gene \\
\hline GI & Gastrointestinal \\
\hline GNAS & Guanine nucleotide-binding protein, alpha stimulating \\
\hline GRB2 & Growth factor receptor bound protein 2 \\
\hline HVDDR & Hereditary $1,25(\mathrm{OH})_{2}$ D-resistant rickets \\
\hline IBGC & Idiopathic basal ganglia calcification \\
\hline
\end{tabular}




\begin{tabular}{|c|c|}
\hline IC & Intracellular \\
\hline ICF & Intracellular fluid \\
\hline IU & International units \\
\hline IP6K1 & Inositol hexakisphosphate kinase 1 \\
\hline IP6K2 & Inositol hexakisphosphate kinase 2 \\
\hline IP6 & Inositol hexakisphosphate \\
\hline IP7 & 5-diphosphoinositol 1,2,3,4,6-pentakisphosphate \\
\hline IP8 & 1,5-bisdiphosphoinositol 1,2,3,4-tetrakisphosphate \\
\hline IV & Intravenous \\
\hline JAM2 & Junctional adhesion molecule 2 \\
\hline KL & $\alpha$-Klotho \\
\hline $\mathrm{K}_{\mathrm{m}}$ & Michaelis-Menten affinity constant \\
\hline LOF & Loss of function \\
\hline LVH & Left ventricular hypertrophy \\
\hline MAPK & Mitogen-activated protein kinase \\
\hline MAPK1 & Mitogen-activated protein kinase 1 \\
\hline MAPK3 & Mitogen-activated protein kinase 3 \\
\hline MEPE & Matrix extracellular phosphoglycoprotein \\
\hline mPTP & Mitochondrial permeability transition pore \\
\hline MV & Matrix vesicle \\
\hline MYORG & Myogenesis regulating glycosidase \\
\hline $\mathrm{Na}^{+}$ & Sodium ion \\
\hline NAD & Nicotinamide adenine dinucleotide \\
\hline $\mathrm{NADH}$ & Reduced nicotinamide adenine dinucleotide \\
\hline NADPH & Reduced nicotinamide adenine dinucleotide phosphate \\
\hline NF-кB & Nuclear factor kappa-light-chain-enhancer of activated B cells \\
\hline NHE3 & Sodium/hydrogen exchanger isoform 3 \\
\hline NHERF-1 & $\mathrm{Na}^{+} / \mathrm{H}^{+}$exchanger regulatory factor \\
\hline NOS & Nitric oxide synthase \\
\hline NPT1 & Sodium-dependent phosphate transport protein 1 \\
\hline NPT2a & Sodium-dependent phosphate transport protein $2 \mathrm{a}$ \\
\hline NPT2b & Sodium-dependent phosphate transport protein $2 \mathrm{~b}$ \\
\hline NPT2c & Sodium-dependent phosphate transport protein $2 c$ \\
\hline NVU & Neurovascular unit \\
\hline OPG & Osteoprotegerin \\
\hline OPN & Osteopontin \\
\hline P10 & Postnatal day 10 \\
\hline PDGFB & Platelet-derived growth factor subunit B \\
\hline PDGFRB & Platelet-derived growth factor receptor beta \\
\hline PFA & Phosphonoformate/phosphonoformic acid \\
\hline PFBC & Primary familial brain calcification \\
\hline Phex & Phosphate-regulating endopeptidase homolog, X-linked \\
\hline PHOSPHO1 & Phosphoethanolamine/phosphocholine phosphatase 1 \\
\hline $\mathrm{P}_{\mathrm{i}}$ & Inorganic phosphate \\
\hline PIC & Mitochondrial phosphate carrier \\
\hline PIT1 & Type III sodium-dependent phosphate transporter 1 \\
\hline PIT2 & Type III sodium-dependent phosphate transporter 2 \\
\hline PKA & Protein kinase A \\
\hline PKC & Protein kinase C \\
\hline PLC $\gamma$ & Phospholipase C gamma isoform. \\
\hline $\mathrm{PP}_{\mathrm{i}}$ & Pyrophosphate \\
\hline PPIs & Proton pump inhibitors \\
\hline PTH & Parathyroid hormone \\
\hline PTHR1 & Parathyroid hormone 1 receptor \\
\hline RANK & Receptor activator of NF- $\mathrm{kB}$ \\
\hline
\end{tabular}




$\begin{array}{ll}\text { RANKL } & \text { Receptor activator of NF-kB ligand } \\ \text { RDA } & \text { Recommended daily allowance } \\ \text { RNA } & \text { Ribonucleic acid } \\ \text { ROS } & \text { Reactive oxygen species } \\ \text { RXR } & \text { Retinoic acid X-receptor } \\ \text { SAMD9 } & \text { Sterile alpha motif domain containing 9 } \\ \text { SIBLING } & \text { Small integrin-binding ligand, N-linked glycoprotein } \\ \text { SLC17 } & \text { Solute carrier family 17 } \\ \text { SLC20A1 } & \text { Solute carrier family 20 member 1; gene encoding PIT1 } \\ \text { SLC20A2 } & \text { Solute carrier family 20 member 2; gene encoding PIT2 } \\ \text { SLC25A3 } & \text { Solute carrier family 25 member 3; gene encoding PIC } \\ \text { SLC34A1 } & \text { Solute carrier family 34 member 3; gene encoding NPT2a } \\ \text { SLC34A2 } & \text { Solute carrier family 34 member 2; gene encoding NPT2b } \\ \text { SLC34A3 } & \text { Solute carrier family 34 member 3; gene encoding NPT2c } \\ \text { SM } & \text { Standard medium } \\ \text { SOS } & \text { Son of sevenless } \\ \text { SPX } & \text { A protein domain named after SYG1/Pho81/XPR1 proteins } \\ \text { TEER } & \text { Transepithelial electrical resistance } \\ \text { TNAP } & \text { Tissue non-specific alkaline phosphatase } \\ \text { TNFRSF11B } & \text { TNF receptor superfamily member 11B } \\ \text { V } \text { ATP } & \text { ATP flux } \\ \text { VDR } & \text { Vitamin D receptor } \\ \text { VRE } & \text { Vitamin D-reponsive elements } \\ \text { VSMC } & \text { Vascular smooth muscle cell } \\ \text { WNT } & \text { Wingless-related integration site } \\ \text { WT } & \text { Wild-type } \\ \text { XLH } & \text { X-linked hyperphosphatemia } \\ \text { XPR1 } & \text { Xenotropic and polytropic retrovirus receptor 1 } \\ & \end{array}$

\section{References}

1. Fukumoto, S. Phosphate metabolism and vitamin d. Bonekey Rep. 2014, 3, 3. [CrossRef]

2. Kher, K.; Schnaper, H.W.; Greenbaum, L.A. Clinical Pediatric Nephrology, 3rd ed.; CRC Press: Boca Raton, FL, USA, 2016.

3. Bevington, A.; Kemp, G.J.; Graham, R.; Russell, G. Phosphate-sensitive enzymes: Possible molecular basis for cellular disorders of phosphate metabolism. Clin. Chem. Enzym. Comms. 1992, 4, 235-257.

4. Chakraborty, A.; Kim, S.; Snyder, S.H. Inositol pyrophosphates as mammalian cell signals. Sci. Signal. 2011, 4, re1. [CrossRef] [PubMed]

5. Angelova, P.R.; Baev, A.Y.; Berezhnov, A.V.; Abramov, A.Y. Role of inorganic polyphosphate in mammalian cells: From signal transduction and mitochondrial metabolism to cell death. Biochem. Soc. Trans. 2016, 44, 40-45. [CrossRef] [PubMed]

6. Boullion, R. Vitamin d: From photosynthesis, metabolism, and action to clinical application. In Endocrinology; Elsevier Saunders: Philadelphia, PA, USA, 2006; pp. 1435-1463.

7. Raisz, L.; Trummel, C.; Holick, M.; DeLuca, H. 1,25-dihydroxycholecalciferol: A potent stimulator of bone resorption in tissue culture. Science 1972, 175, 768-769. [CrossRef]

8. Ravid, M.; Robson, M. Proximal myopathy caused by latrogenic phosphate depletion. JAMA 1976, 236, 1380-1381. [CrossRef]

9. Halevy, J.; Bulvik, S. Severe hypophosphatemia in hospitalized patients. JAMA Intern. Med. 1988, 148, 153-155. [CrossRef]

10. Goodman, W.G.; Goldin, J.; Kuizon, B.D.; Yoon, C.; Gales, B.; Sider, D.; Wang, Y.; Chung, J.; Emerick, A.; Greaser, L.; et al. Coronary-artery calcification in young adults with end-stage renal disease who are undergoing dialysis. N. Engl. J. Med. 2000, 342, 1478-1483. [CrossRef]

11. Hou, Y.; Li, X.; Sun, L.; Qu, Z.; Jiang, L.; Du, Y. Phosphorus and mortality risk in end-stage renal disease: A meta-analysis. Clin. Chim. Acta 2017, 474, 108-113. [CrossRef] 
12. O'Seaghdha, C.M.; Hwang, S.J.; Muntner, P.; Melamed, M.L.; Fox, C.S. Serum phosphorus predicts incident chronic kidney disease and end-stage renal disease. Nephrol. Dial. Transpl. 2011, 26, 2885-2890. [CrossRef]

13. Sim, J.J.; Bhandari, S.K.; Smith, N.; Chung, J.; Liu, I.L.; Jacobsen, S.J.; Kalantar-Zadeh, K. Phosphorus and risk of renal failure in subjects with normal renal function. Am. J. Med. 2013, 126, 311-318. [CrossRef] [PubMed]

14. Bergwitz, C.; Juppner, H. Regulation of phosphate homeostasis by pth, vitamin d, and fgf23. Annu. Rev. Med. 2010, 61, 91-104. [CrossRef] [PubMed]

15. Manghat, P.; Sodi, R.; Swaminathan, R. Phosphate homeostasis and disorders. Ann. Clin. Biochem. 2014, 51, 631-656. [CrossRef] [PubMed]

16. Naidu, R.; Rengasamy, P. Ion interactions and constraints to plant nutrition in australian sodic soils. Aust. J. Soil Res. 1993, 31, 801-819. [CrossRef]

17. Kawa, D.; Julkowska, M.M.; Sommerfeld, H.M.; Ter Horst, A.; Haring, M.A.; Testerink, C. Phosphate-dependent root system architecture responses to salt stress. Plant. Physiol. 2016, 172, 690-706. [CrossRef] [PubMed]

18. Vorland, C.J.; Stremke, E.R.; Moorthi, R.N.; Hill Gallant, K.M. Effects of excessive dietary phosphorus intake on bone health. Curr. Osteoporos. Rep. 2017, 15, 473-482. [CrossRef]

19. Karalis, M. Food and drug administration petition on food labeling: An update from the american dietetic association and national kidney foundation. J. Ren. Nutr. 2007, 17, 423-424. [CrossRef]

20. Calvo, M.S.; Moshfegh, A.J.; Tucker, K.L. Assessing the health impact of phosphorus in the food supply: Issues and considerations. Adv. Nutr. 2014, 5, 104-113. [CrossRef]

21. Carpenter, T.O.; Bergwitz, C.; Insogna, K.L. Chapter 20-Phosphorus homeostasis and related disorders. In Principles of Bone Biology, 4th ed.; Bilezikian, J.P., Martin, T.J., Clemens, T.L., Rosen, C.J., Eds.; Academic Press: Cambridge, MA, USA, 2020; pp. 469-507.

22. Goretti Penido, M.; Alon, U.S. Phosphate homeostasis and its role in bone health. Pediatr. Nephrol. 2012, 27, 2039-2048. [CrossRef]

23. Eto, N.; Tomita, M.; Hayashi, M. Napi-mediated transcellular permeation is the dominant route in intestinal inorganic phosphate absorption in rats. Drug Metab. Pharm. 2006, 21, 217-221. [CrossRef]

24. Berndt, T.; Kumar, R. Novel mechanisms in the regulation of phosphorus homeostasis. Physiology 2009, 24, 17-25. [CrossRef] [PubMed]

25. Murer, H.; Forster, I.; Biber, J. The sodium phosphate cotransporter family slc34. Pflug. Archiv. 2004, 447, 763-767. [CrossRef] [PubMed]

26. Murer, H.; Hernando, N.; Forster, I.; Biber, J. Proximal tubular phosphate reabsorption: Molecular mechanisms. Physiol. Rev. 2000, 80, 1373-1409. [CrossRef] [PubMed]

27. Lee, G.J.; Marks, J. Intestinal phosphate transport: A therapeutic target in chronic kidney disease and beyond? Pediatr. Nephrol. 2015, 30, 363-371. [CrossRef]

28. Crook, M.; Swaminathan, R. Disorders of plasma phosphate and indications for its measurement. Ann. Clin. Biochem. 1996, 33, 376-396. [CrossRef]

29. Benjamin, I.; Griggs, R.C.; Fitz, J.G.; Wing, E.J. Andreoli and Carpenter's Cecil Essentials of Medicine E-Book; Elsevier Health Sciences: Amsterdam, The Netherlands, 2015.

30. Marks, J.; Lee, G.J.; Nadaraja, S.P.; Debnam, E.S.; Unwin, R.J. Experimental and regional variations in $\mathrm{Na}^{+}$-dependent and $\mathrm{na}^{+}$-independent phosphate transport along the rat small intestine and colon. Physiol. Rep. 2015, 3, e12281. [CrossRef]

31. Knöpfel, T.; Himmerkus, N.; Günzel, D.; Bleich, M.; Hernando, N.; Wagner, C.A. Paracellular transport of phosphate along the intestine. Am. J. Physiol. Gastrointest. Liver Physiol. 2019, 317, G233-G241. [CrossRef]

32. Hu, M.S.; Kayne, L.H.; Jamgotchian, N.; Ward, H.J.; Lee, D.B. Paracellular phosphate absorption in rat colon: A mechanism for enema-induced hyperphosphatemia. Miner. Electrolyte Metab. 1997, 23, 7-12.

33. Marks, J. The role of slc34a2 in intestinal phosphate absorption and phosphate homeostasis. Pflug. Arch. 2019, 471, 165-173. [CrossRef]

34. Hilfiker, H.; Hattenhauer, O.; Traebert, M.; Forster, I.; Murer, H.; Biber, J. Characterization of a murine type ii sodium-phosphate cotransporter expressed in mammalian small intestine. Proc. Natl. Acad. Sci. USA 1998, 95, 14564-14569. [CrossRef]

35. Sabbagh, Y.; O’Brien, S.P.; Song, W.; Boulanger, J.H.; Stockmann, A.; Arbeeny, C.; Schiavi, S.C. Intestinal npt2b plays a major role in phosphate absorption and homeostasis. J. Am. Soc. Nephrol. 2009, 20, 2348-2358. [CrossRef] [PubMed] 
36. Sabbagh, Y.; Giral, H.; Caldas, Y.; Levi, M.; Schiavi, S.C. Intestinal phosphate transport. Adv. Chronic Kidney Dis. 2011, 18, 85-90. [CrossRef] [PubMed]

37. Giral, H.; Caldas, Y.; Sutherland, E.; Wilson, P.; Breusegem, S.; Barry, N.; Blaine, J.; Jiang, T.; Wang, X.X.; Levi, M. Regulation of rat intestinal na-dependent phosphate transporters by dietary phosphate. Am. J. Physiol. Ren. Physiol. 2009, 297, F1466-F1475. [CrossRef] [PubMed]

38. Wilz, D.R.; Gray, R.W.; Dominguez, J.H.; Lemann, J., Jr. Plasma 1,25-(oh)2-vitamin d concentrations and net intestinal calcium, phosphate, and magnesium absorption in humans. Am. J. Clin. Nutr. 1979, 32, 2052-2060. [CrossRef]

39. Hattenhauer, O.; Traebert, M.; Murer, H.; Biber, J. Regulation of small intestinal Na-p(i) type iib cotransporter by dietary phosphate intake. Am. J. Physiol. 1999, 277, G756-G762. [CrossRef]

40. Forster, I.C.; Loo, D.D.F.; Eskandari, S. Stoichiometry and $\mathrm{Na}^{+}$binding cooperativity of rat and flounder renal type II $\mathrm{Na}^{+}$-picotransporters. Am. J. Physiol. Ren. Physiol. 1999, 276, F644-F649. [CrossRef]

41. Forster, I.C.; Virkki, L.; Bossi, E.; Murer, H.; Biber, J. Electrogenic kinetics of a mammalian intestinal type IIb $\mathrm{Na}^{+} / \mathrm{Pi}$ cotransporter. J. Membr. Biol. 2006, 212, 177-190. [CrossRef]

42. Zhifeng, X.; Rejun, F.; Longchang, H.; Wenqing, S. Molecular cloning and functional characterization of swine sodium dependent phosphate cotransporter type II b (NaPi-IIb) gene. Mol. Biol. Rep. 2012, 39, 10557-10564. [CrossRef]

43. Quarles, L.D. A systems biology preview of the relationships between mineral and metabolic complications in chronic kidney disease. Semin. Nephrol. 2013, 33, 130-142. [CrossRef]

44. Brame, L.A.; White, K.E.; Econs, M.J. Renal phosphate wasting disorders: Clinical features and pathogenesis. Semin. Nephrol. 2004, 24, 39-47. [CrossRef]

45. Lederer, E. Regulation of serum phosphate. J. Physiol. 2014, 592, 3985-3995. [CrossRef] [PubMed]

46. Chande, S.; Bergwitz, C. Role of phosphate sensing in bone and mineral metabolism. Nat. Rev. Endocrinol. 2018, 14, 637-655. [CrossRef] [PubMed]

47. Camalier, C.E.; Yi, M.; Yu, L.R.; Hood, B.L.; Conrads, K.A.; Lee, Y.J.; Lin, Y.; Garneys, L.M.; Bouloux, G.F.; Young, M.R.; et al. An integrated understanding of the physiological response to elevated extracellular phosphate. J. Cell Physiol. 2013, 228, 1536-1550. [CrossRef] [PubMed]

48. Takashi, Y.; Fukumoto, S. Phosphate-sensing and regulatory mechanism of fgf23 production. J. Endocrinol. Investig. 2020, 43, 877-883. [CrossRef]

49. Braegger, C.; Decsi, T.; Dias, J.A.; Hartman, C.; Kolacek, S.; Koletzko, B.; Koletzko, S.; Mihatsch, W.; Moreno, L.; Puntis, J.; et al. Practical approach to paediatric enteral nutrition: A comment by the espghan committee on nutrition. J. Pediatr. Gastroenterol. Nutr. 2010, 51, 110-122. [CrossRef]

50. Portale, A.A.; Halloran, B.P.; Morris, R.C., Jr. Dietary intake of phosphorus modulates the circadian rhythm in serum concentration of phosphorus. Implications for the renal production of 1,25-dihydroxyvitamin $\mathrm{d}$. J. Clin. Investig. 1987, 80, 1147-1154. [CrossRef]

51. Torres, P.A.U.; De Brauwere, D.P. Three feedback loops precisely regulating serum phosphate concentration. Kidney Int. 2011, 80, 443-445. [CrossRef]

52. Zierold, C.; Darwish, H.M.; DeLuca, H.F. Two vitamin d response elements function in the rat 1,25-dihydroxyvitamin d 24-hydroxylase promoter. J. Biol. Chem. 1995, 270, 1675-1678. [CrossRef]

53. Pike, J.W.; Meyer, M.B. The vitamin d receptor: New paradigms for the regulation of gene expression by 1,25-dihydroxyvitamin d(3). Endocrinol. Metab. Clin. N. Am. 2010, 39, 255-269. [CrossRef]

54. Bikle, D.D. Vitamin d metabolism, mechanism of action, and clinical applications. Chem. Biol. 2014, 21, 319-329. [CrossRef]

55. Kaneko, I.; Segawa, H.; Furutani, J.; Kuwahara, S.; Aranami, F.; Hanabusa, E.; Tominaga, R.; Giral, H.; Caldas, Y.; Levi, M.; et al. Hypophosphatemia in vitamin d receptor null mice: Effect of rescue diet on the developmental changes in renal $\mathrm{Na}^{+}$-dependent phosphate cotransporters. Pflug. Arch. 2011, 461, 77-90. [CrossRef] [PubMed]

56. Marks, J.; Srai, S.K.; Biber, J.; Murer, H.; Unwin, R.J.; Debnam, E.S. Intestinal phosphate absorption and the effect of vitamin D: A comparison of rats with mice. Exp. Physiol. 2006, 91, 531-537. [CrossRef] [PubMed]

57. Segawa, H.; Kaneko, I.; Takahashi, A.; Kuwahata, M.; Ito, M.; Ohkido, I.; Tatsumi, S.; Miyamoto, K. Growth-related renal type II Na/Pi cotransporter. J. Biol. Chem. 2002, 277, 19665-19672. [CrossRef] [PubMed]

58. Miyamoto, K.; Segawa, H.; Ito, M.; Kuwahata, M. Physiological regulation of renal sodium-dependent phosphate cotransporters. Jpn. J. Physiol. 2004, 54, 93-102. [CrossRef] [PubMed] 
59. Shimada, T.; Urakawa, I.; Yamazaki, Y.; Hasegawa, H.; Hino, R.; Yoneya, T.; Takeuchi, Y.; Fujita, T.; Fukumoto, S.; Yamashita, T. Fgf-23 transgenic mice demonstrate hypophosphatemic rickets with reduced expression of sodium phosphate cotransporter type iia. Biochem. Biophys. Res. Commun. 2004, 314, 409-414. [CrossRef] [PubMed]

60. Capuano, P.; Radanovic, T.; Wagner, C.A.; Bacic, D.; Kato, S.; Uchiyama, Y.; St-Arnoud, R.; Murer, H.; Biber, J. Intestinal and renal adaptation to a low-pi diet of type II NaPi cotransporters in vitamin d receptor- and 1alphaohase-deficient mice. Am. J. Physiol. Cell Physiol. 2005, 288, C429-C434. [CrossRef]

61. Xu, H.; Uno, J.K.; Inouye, M.; Xu, L.; Drees, J.B.; Collins, J.F.; Ghishan, F.K. Regulation of intestinal NaPi-IIb cotransporter gene expression by estrogen. Am. J. Physiol. Gastrointest. Liver Physiol. 2003, 285, G1317-G1324. [CrossRef]

62. Arima, K.; Hines, E.R.; Kiela, P.R.; Drees, J.B.; Collins, J.F.; Ghishan, F.K. Glucocorticoid regulation and glycosylation of mouse intestinal type Ilb Na-Pi cotransporter during ontogeny. Am. J. Physiol. Gastrointest. Liver Physiol. 2002, 283, G426-G434. [CrossRef]

63. Biol, M.-C.; Lenoir, D.; Hugueny, I.; Louisot, P. Hormonal regulation of glycosylation process in rat small intestine: Responsiveness of fucosyl-transferase activity to hydrocortisone during the suckling period, unresponsiveness after weaning. Biochim. Biophys. Acta (BBA) Mol. Cell Res. 1992, 1133, 206-212. [CrossRef]

64. Xu, H.; Collins, J.F.; Bai, L.; Kiela, P.R.; Ghishan, F.K. Regulation of the human sodium-phosphate cotransporter napi-iib gene promoter by epidermal growth factor. Am. J. Physiol. Cell Physiol. 2001, 280, C628-C636. [CrossRef]

65. Xu, H.; Inouye, M.; Hines, E.R.; Collins, J.F.; Ghishan, F.K. Transcriptional regulation of the human Napi-Illb cotransporter by egf in caco-2 cells involves c-myb. Am. J. Physiol. Cell Physiol. 2003, 284, C1262-C1271.

66. Forster, I.C.; Hernando, N.; Biber, J.; Murer, H. Proximal tubular handling of phosphate: A molecular perspective. Kidney Int. 2006, 70, 1548-1559. [PubMed]

67. Howard, G.A.; Bottemiller, B.L.; Turner, R.T.; Rader, J.I.; Baylink, D.J. Parathyroid hormone stimulates bone formation and resorption in organ culture: Evidence for a coupling mechanism. Proc. Natl. Acad. Sci. USA 1981, 78, 3204.

68. Silva, B.C.; Bilezikian, J.P. Parathyroid hormone: Anabolic and catabolic actions on the skeleton. Curr. Opin. Pharm. 2015, 22, 41-50.

69. Weinman, E.J.; Biswas, R.S.; Peng, Q.; Shen, L.; Turner, C.L.; E, X.; Steplock, D.; Shenolikar, S.; Cunningham, R. Parathyroid hormone inhibits renal phosphate transport by phosphorylation of serine 77 of sodium-hydrogen exchanger regulatory factor-1. J. Clin. Investig. 2007, 117, 3412-3420. [PubMed]

70. Bacic, D.; Lehir, M.; Biber, J.; Kaissling, B.; Murer, H.; Wagner, C.A. The renal Na ${ }^{+} /$phosphate cotransporter napi-iia is internalized via the receptor-mediated endocytic route in response to parathyroid hormone. Kidney Int. 2006, 69, 495-503.

71. Traebert, M.; Völkl, H.; Biber, J.; Murer, H.; Kaissling, B. Luminal and contraluminal action of 1-34 and 3-34 pth peptides on renal type iia na-pi cotransporter. Am. J. Physiol. Ren. Physiol. 2000, 278, F792-F798.

72. Feng, J.Q.; Ward, L.M.; Liu, S.; Lu, Y.; Xie, Y.; Yuan, B.; Yu, X.; Rauch, F.; Davis, S.I.; Zhang, S.; et al. Loss of dmp1 causes rickets and osteomalacia and identifies a role for osteocytes in mineral metabolism. Nat. Genet. 2006, 38, 1310-1315.

73. Liu, S.; Guo, R.; Simpson, L.G.; Xiao, Z.-S.; Burnham, C.E.; Quarles, L.D. Regulation of fibroblastic growth factor 23 expression but not degradation by phex. J. Biol. Chem. 2003, 278, 37419-37426.

74. Lu, Y.; Feng, J.Q. Fgf23 in skeletal modeling and remodeling. Curr. Osteoporos. Rep. 2011, 9, $103-108$.

75. Shimada, T.; Hasegawa, H.; Yamazaki, Y.; Muto, T.; Hino, R.; Takeuchi, Y.; Fujita, T.; Nakahara, K.; Fukumoto, S.; Yamashita, T. Fgf-23 is a potent regulator of vitamin d metabolism and phosphate homeostasis. J. Bone Miner. Res. 2004, 19, 429-435. [CrossRef] [PubMed]

76. Farrow, E.G.; White, K.E. Recent advances in renal phosphate handling. Nat. Rev. Nephrol. 2010, 6, $207-217$. [CrossRef] [PubMed]

77. Burnett, S.M.; Gunawardene, S.C.; Bringhurst, F.R.; Jüppner, H.; Lee, H.; Finkelstein, J.S. Regulation of c-terminal and intact fgf-23 by dietary phosphate in men and women. J. Bone Miner. Res. 2006, 21, 1187-1196. [CrossRef] [PubMed]

78. Yan, X.; Yokote, H.; Jing, X.; Yao, L.; Sawada, T.; Zhang, Y.; Liang, S.; Sakaguchi, K. Fibroblast growth factor 23 reduces expression of type iia na+/pi co-transporter by signaling through a receptor functionally distinct from the known fgfrs in opossum kidney cells. Genes Cells 2005, 10, 489-502. [CrossRef] 
79. Chen, G.; Liu, Y.; Goetz, R.; Fu, L.; Jayaraman, S.; Hu, M.C.; Moe, O.W.; Liang, G.; Li, X.; Mohammadi, M. Alpha-klotho is a non-enzymatic molecular scaffold for fgf 23 hormone signalling. Nature 2018, 553, 461-466. [CrossRef]

80. Urakawa, I.; Yamazaki, Y.; Shimada, T.; Iijima, K.; Hasegawa, H.; Okawa, K.; Fujita, T.; Fukumoto, S.; Yamashita, T. Klotho converts canonical fgf receptor into a specific receptor for fgf23. Nature 2006, 444, 770-774. [CrossRef]

81. Andrukhova, O.; Zeitz, U.; Goetz, R.; Mohammadi, M.; Lanske, B.; Erben, R.G. Fgf23 acts directly on renal proximal tubules to induce phosphaturia through activation of the erk1/2-sgk1 signaling pathway. Bone 2012, 51, 621-628. [CrossRef]

82. Liu, S.; Tang, W.; Zhou, J.; Stubbs, J.R.; Luo, Q.; Pi, M.; Quarles, L.D. Fibroblast growth factor 23 is a counter-regulatory phosphaturic hormone for vitamin D. J. Am. Soc. Nephrol. 2006, 17, 1305-1315. [CrossRef]

83. Lang, F.; Leibrock, C.; Pandyra, A.A.; Stournaras, C.; Wagner, C.A.; Föller, M. Phosphate homeostasis, inflammation and the regulation of fgf-23. Kidney Blood Press. Res. 2018, 43, 1742-1748. [CrossRef]

84. Gattineni, J.; Friedman, P.A. Regulation of hormone-sensitive renal phosphate transport. Vitam. Horm. 2015, 98, 249-306.

85. Norman, A.W. The history of the discovery of vitamin d and its daughter steroid hormone. Ann. Nutr. Metab. 2012, 61, 199-206. [CrossRef] [PubMed]

86. Petkovich, M.; Jones, G. Cyp24a1 and kidney disease. Curr. Opin. Nephrol. Hypertens. 2011, 20, 337-344. [CrossRef] [PubMed]

87. Jones, G.; Prosser, D.E.; Kaufmann, M. 25-hydroxyvitamin d-24-hydroxylase (cyp24a1): Its important role in the degradation of vitamin D. Arch. Biochem. Biophys. 2012, 523, 9-18. [CrossRef]

88. Carpenter, T.O.; Shiratori, T. Renal 25-hydroxyvitamin d-1 alpha-hydroxylase activity and mitochondrial phosphate transport in hyp mice. Am. J. Physiol. 1990, 259, E814-E821. [CrossRef] [PubMed]

89. Kaufmann, M.; Lee, S.M.; Pike, J.W.; Jones, G. A high-calcium and phosphate rescue diet and vdr-expressing transgenes normalize serum vitamin d metabolite profiles and renal cyp27b1 and cyp24a1 expression in vdr null mice. Endocrinology 2015, 156, 4388-4397. [CrossRef]

90. Sahay, M.; Sahay, R.K. Refractory rickets in tropics. J. Pediatr. Endocrinol. Metab. 2010, 23, 597. [CrossRef]

91. Duncan, W.E. Chapter 11-Osteomalacia and rickets. In Endocrine Secrets, 5th ed.; McDermott, M.T., Ed.; Mosby: Philadelphia, PA, USA, 2009; pp. 110-116.

92. Knochel, J.P.; Barcenas, C.; Cotton, J.R.; Fuller, T.J.; Haller, R.; Carter, N.W. Hypophosphatemia and rhabdomyolysis. J. Clin. Investig. 1978, 62, 1240-1246. [CrossRef]

93. Darsee, J.R.; Nutter, D.O. Reversible severe congestive cardiomyopathy in three cases of hypophosphatemia. Ann. Intern. Med. 1978, 89, 867-870. [CrossRef]

94. Craddock, P.R.; Yawata, Y.; VanSanten, L.; Gilberstadt, S.; Silvis, S.; Jacob, H.S. Acquired phagocyte dysfunction. A complication of the hypophosphatemia of parenteral hyperalimentation. N. Engl. J. Med. 1974, 290, 1403-1407. [CrossRef]

95. Sullivan, C.; Sayre, S.S.; Leon, J.B.; Machekano, R.; Love, T.E.; Porter, D.; Marbury, M.; Sehgal, A.R. Effect of food additives on hyperphosphatemia among patients with end-stage renal disease: A randomized controlled trial. JAMA 2009, 301, 629-635. [CrossRef]

96. León, J.B.; Sullivan, C.M.; Sehgal, A.R. The prevalence of phosphorus-containing food additives in top-selling foods in grocery stores. J. Ren. Nutr. 2013, 23, 265-270.e262. [CrossRef]

97. Cupisti, A.; Kalantar-Zadeh, K. Management of natural and added dietary phosphorus burden in kidney disease. Semin. Nephrol. 2013, 33, 180-190. [CrossRef] [PubMed]

98. Carrigan, A.; Klinger, A.; Choquette, S.S.; Luzuriaga-McPherson, A.; Bell, E.K.; Darnell, B.; Gutiérrez, O.M. Contribution of food additives to sodium and phosphorus content of diets rich in processed foods. J. Ren. Nutr. 2014, 24, 13-19.e11. [CrossRef]

99. EFSA Panel on Dietetic Products; Nutrition and Allergies (NDA). Scientific opinion on dietary reference values for phosphorus. EFSA J. 2015, 13, 4185.

100. Hannah, J.; Roe, M.; Warthon-Medina, M.; Pinchen, H.; Barrett, M.; Perry, S. Phosphorus in food: Limitations of food composition data. J. Kidney Care 2018, 3, 362-367. [CrossRef]

101. Chang, A.R.; Lazo, M.; Appel, L.J.; Gutierrez, O.M.; Grams, M.E. High dietary phosphorus intake is associated with all-cause mortality: Results from NHANES III. Am. J. Clin. Nutr. 2014, 99, 320-327. [CrossRef] [PubMed] 
102. Carpenter, T.O.; Imel, E.A.; Holm, I.A.; Jan de Beur, S.M.; Insogna, K.L. A clinician's guide to x-linked hypophosphatemia. J. Bone Miner. Res. 2011, 26, 1381-1388. [CrossRef]

103. Liamis, G.; Milionis, H.J.; Elisaf, M. Medication-induced hypophosphatemia: A review. QJM An. Int. J. Med. 2010, 103, 449-459. [CrossRef]

104. Disorders of phosphate homeostasis. In Primer on the Metabolic Bone Diseases and Disorders of Mineral Metabolism; Wiley: Hoboken, NJ, USA, 2008; pp. 674-683.

105. FFass, R.; Do, S.; Hixson, L.J. Fatal hyperphosphatemia following fleet phospo-soda in a patient with colonic ileus. Am. J. Gastroenterol. 1993, 88, 929-932.

106. Fine, A.; Patterson, J. Severe hyperphosphatemia following phosphate administration for bowel preparation in patients with renal failure: Two cases and a review of the literature. Am. J. Kidney Dis. 1997, 29, 103-105. [CrossRef]

107. Parikh, M.J.; Dumas, G.; Silvestri, A.; Bistrian, B.R.; Driscoll, D.F. Physical compatibility of neonatal total parenteral nutrient admixtures containing organic calcium and inorganic phosphate salts. Am. J. Health Syst. Pharm. 2005, 62, 1177-1183. [CrossRef] [PubMed]

108. MacKay, M.; Jackson, D.; Eggert, L.; Fitzgerald, K.; Cash, J. Practice-based validation of calcium and phosphorus solubility limits for pediatric parenteral nutrition solutions. Nutr. Clin. Pract. 2011, 26, 708-713. [CrossRef] [PubMed]

109. Gonzalez Ballesteros, L.F.; Ma, N.S.; Gordon, R.J.; Ward, L.; Backeljauw, P.; Wasserman, H.; Weber, D.R.; DiMeglio, L.A.; Gagne, J.; Stein, R.; et al. Unexpected widespread hypophosphatemia and bone disease associated with elemental formula use in infants and children. Bone 2017, 97, 287-292. [CrossRef] [PubMed]

110. Candeal, E.; Caldas, Y.A.; Guillén, N.; Levi, M.; Sorribas, V. Intestinal phosphate absorption is mediated by multiple transport systems in rats. Am. J. Physiol. Gastrointest. Liver Physiol. 2017, 312, G355-G366. [CrossRef]

111. Lotz, M.; Zisman, E.; Bartter, F.C. Evidence for a phosphorus-depletion syndrome in man. N. Engl. J. Med. 1968, 278, 409-415. [CrossRef] [PubMed]

112. Chines, A.; Pacifici, R. Antacid and sucralfate-induced hypophosphatemic osteomalacia: A case report and review of the literature. Calcif. Tissue Int. 1990, 47, 291-295. [CrossRef] [PubMed]

113. Kim, O.-H.; Booth, C.J.; Choi, H.S.; Lee, J.; Kang, J.; Hur, J.; Jung, W.J.; Jung, Y.-S.; Choi, H.J.; Kim, H.; et al. High-phytate/low-calcium diet is a risk factor for crystal nephropathies, renal phosphate wasting, and bone loss. eLife 2020, 9, e52709. [CrossRef]

114. Kim, O.H.; Kim, Y.O.; Shim, J.H.; Jung, Y.S.; Jung, W.J.; Choi, W.C.; Lee, H.; Lee, S.J.; Kim, K.K.; Auh, J.H.; et al. B-propeller phytase hydrolyzes insoluble $\mathrm{Ca}(2+)$-phytate salts and completely abrogates the ability of phytate to chelate metal ions. Biochemistry 2010, 49, 10216-10227. [CrossRef]

115. Villa-Bellosta, R.; Sorribas, V. Role of rat sodium/phosphate cotransporters in the cell membrane transport of arsenate. Toxicol. Appl. Pharmacol. 2008, 232, 125-134. [CrossRef]

116. Peerce, B.E.; Clarke, R. A phosphorylated phloretin derivative. Synthesis and effect on intestinal na+-dependent phosphate absorption. Am. J. Physiol. Gastrointest. Liver Physiol. 2002, 283, G848-G855. [CrossRef]

117. Katai, K.; Tanaka, H.; Tatsumi, S.; Fukunaga, Y.; Genjida, K.; Morita, K.; Kuboyama, N.; Suzuki, T.; Akiba, T.; Miyamoto, K.; et al. Nicotinamide inhibits sodium-dependent phosphate cotransport activity in rat small intestine. Nephrol. Dial. Transpl. 1999, 14, 1195-1201. [CrossRef] [PubMed]

118. Sorribas, V.; Guillén, N.; Sosa, C. Substrates and inhibitors of phosphate transporters: From experimental tools to pathophysiological relevance. Pflug. Arch. 2019, 471, 53-65. [CrossRef]

119. Matsuo, A.; Negoro, T.; Seo, T.; Kitao, Y.; Shindo, M.; Segawa, H.; Miyamoto, K. Inhibitory effect of jtp-59557, a new triazole derivative, on intestinal phosphate transport in vitro and in vivo. Eur. J. Pharm. 2005, 517, 111-119. [CrossRef] [PubMed]

120. King, A.J.; Siegel, M.; He, Y.; Nie, B.; Wang, J.; Koo-McCoy, S.; Minassian, N.A.; Jafri, Q.; Pan, D.; Kohler, J.; et al. Inhibition of sodium/hydrogen exchanger 3 in the gastrointestinal tract by tenapanor reduces paracellular phosphate permeability. Sci. Transl. Med. 2018, 10, eaam6474. [CrossRef]

121. Del Valle, H.B.; Yaktine, A.L.; Taylor, C.L.; Ross, A.C. Dietary Reference Intakes for Calcium and Vitamin D; National Academies Press: Cambridge, MA, USA, 2011.

122. Marcinowska-Suchowierska, E.; Kupisz-Urbańska, M.; Łukaszkiewicz, J.; Płudowski, P.; Jones, G. Vitamin D toxicity-a clinical perspective. Front. Endocrinol. 2018, 9, 550. [CrossRef] [PubMed] 
123. Joist, H.E.; Ahya, S.N.; Giles, K.; Norwood, K.; Slatopolsky, E.; Coyne, D.W. Differential effects of very high doses of doxercalciferol and paricalcitol on serum phosphorus in hemodialysis patients. Clin. Nephrol. 2006, 65, 335-341. [CrossRef]

124. Steingrimsdottir, L.; Gunnarsson, O.; Indridason, O.S.; Franzson, L.; Sigurdsson, G. Relationship between serum parathyroid hormone levels, vitamin d sufficiency, and calcium intake. JAMA 2005, 294, 2336-2341. [CrossRef]

125. Vanhooke, J.L.; Prahl, J.M.; Kimmel-Jehan, C.; Mendelsohn, M.; Danielson, E.W.; Healy, K.D.; DeLuca, H.F. Cyp27b1 null mice with laczreporter gene display no 25-hydroxyvitamin d3-1alpha-hydroxylase promoter activity in the skin. Proc. Natl. Acad. Sci. USA 2006, 103, 75-80. [CrossRef]

126. Jacquillet, G.; Unwin, R.J. Physiological regulation of phosphate by vitamin d, parathyroid hormone (pth) and phosphate (pi). Pflug. Arch. Eur. J. Physiol. 2019, 471, 83-98. [CrossRef]

127. Fine, K.D.; Seidel, R.H.; Do, K. The prevalence, anatomic distribution, and diagnosis of colonic causes of chronic diarrhea. Gastrointest. Endosc. 2000, 51, 318-326. [CrossRef]

128. Sharma, S.; Hashmi, M.F.; Castro, D. Hypophosphatemia; Statpearls: Treasure Island, FL, USA, 2020.

129. Stauber, A.; Radanovic, T.; Stange, G.; Murer, H.; Wagner, C.A.; Biber, J. Regulation of intestinal phosphate transport ii. Metabolic acidosis stimulates na+-dependent phosphate absorption and expression of the na ${ }^{+}$-pi cotransporter napi-iib in small intestine. Am. J. Physiol. Gastrointest. Liver Physiol. 2005, 288, G501-G506. [CrossRef] [PubMed]

130. Nagant de Deuxchaisnes, C.; Devogelaer, J.P. Vitamin d deficiency in elderly people. BMJ 1991, $303,718$. [CrossRef] [PubMed]

131. Vervloet, M.G.; Sezer, S.; Massy, Z.A.; Johansson, L.; Cozzolino, M.; Fouque, D.; on behalf of the ERA-EDTA Working Group on Chronic Kidney Disease-Mineral and Bone Disorders and the European Renal Nutrition Working Group. The role of phosphate in kidney disease. Nat. Rev. Nephrol. 2017, 13, 27-38. [CrossRef] [PubMed]

132. Kulnigg-Dabsch, S. Autoimmune gastritis. Wien. Med. Wochenschr. 2016, 166, 424-430. [CrossRef] [PubMed]

133. Lahner, E.; Annibale, B. Pernicious anemia: New insights from a gastroenterological point of view. World J. Gastroenterol. 2009, 15, 5121-5128. [CrossRef]

134. Edmonston, D.; Wolf, M. Fgf23 at the crossroads of phosphate, iron economy and erythropoiesis. Nat. Rev. Nephrol. 2020, 16, 7-19. [CrossRef]

135. Basile, D.P.; Anderson, M.D.; Sutton, T.A. Pathophysiology of acute kidney injury. Compr. Physiol. 2012, 2, 1303-1353.

136. Moe, O.W.; Seldin, D.W.; Baum, M. Chapter 10-The fanconi syndrome. In Genetic Diseases of the Kidney; Lifton, R.P., Somlo, S., Giebisch, G.H., Seldin, D.W., Eds.; Academic Press: San Diego, CA, USA, 2009; pp. 171-197.

137. Keefe, P.; Bokhari, S.R.A. Fanconi Syndrome; Statpearls: Treasure Island, FL, USA, 2020.

138. Chapter 8-Disorders of calcium, magnesium, and phosphate balance. In Pocket Companion to Brenner and Rector's the Kidney, 8th ed.; Clarkson, M.R.; Magee, C.N.; Brenner, B.M. (Eds.) W.B. Saunders: Philadelphia, PA, USA, 2011; pp. 166-185.

139. Bandeira, F.; Cusano, N.E.; Silva, B.C.; Cassibba, S.; Almeida, C.B.; Machado, V.C.; Bilezikian, J.P. Bone disease in primary hyperparathyroidism. Arq. Bras. Endocrinol. Metab. 2014, 58, 553-561. [CrossRef]

140. Villa-Bellosta, R.; Sorribas, V. Arsenate transport by sodium/phosphate cotransporter type iib. Toxicol. Appl. Pharmacol. 2010, 247, 36-40. [CrossRef]

141. Ginsberg, C.; Ix, J.H. Nicotinamide and phosphate homeostasis in chronic kidney disease. Curr. Opin. Nephrol. Hypertens. 2016, 25, 285-291. [CrossRef]

142. Riley, M.S.; Schade, D.S.; Eaton, R.P. Effects of insulin infusion on plasma phosphate in diabetic patients. Metabolism 1979, 28, 191-194. [CrossRef]

143. Boivin, G.Y.; Chavassieux, P.M.; Santora, A.C.; Yates, J.; Meunier, P.J. Alendronate increases bone strength by increasing the mean degree of mineralization of bone tissue in osteoporotic women. Bone 2000, 27, 687-694. [CrossRef]

144. Boivin, G.; Meunier, P.J. Effects of bisphosphonates on matrix mineralization. J. Musculoskelet. Neuronal Interact. 2002, 2, 538-543.

145. Müller, M.; Cheneval, D.; Carafoli, E. Doxorubicin inhibits the phosphate-transport protein reconstituted in liposomes. Eur. J. Biochem. 1984, 140, 447-452. [CrossRef] [PubMed] 
146. Davidson, M.B.; Thakkar, S.; Hix, J.K.; Bhandarkar, N.D.; Wong, A.; Schreiber, M.J. Pathophysiology, clinical consequences, and treatment of tumor lysis syndrome. Am. J. Med. 2004, 116, 546-554. [CrossRef]

147. Bosch, X.; Poch, E.; Grau, J.M. Rhabdomyolysis and acute kidney injury. N. Engl. J. Med. 2009, 361, 62-72. [CrossRef]

148. Waning, D.L.; Guise, T.A. Molecular mechanisms of bone metastasis and associated muscle weakness. Clin. Cancer Res. 2014, 20, 3071-3077. [CrossRef]

149. Hruska, K.A.; Mathew, S.; Lund, R.; Qiu, P.; Pratt, R. Hyperphosphatemia of chronic kidney disease. Kidney Int. 2008, 74, 148-157. [CrossRef]

150. Wohrle, S.; Henninger, C.; Bonny, O.; Thuery, A.; Beluch, N.; Hynes, N.E.; Guagnano, V.; Sellers, W.R.; Hofmann, F.; Kneissel, M.; et al. Pharmacological inhibition of fibroblast growth factor (fgf) receptor signaling ameliorates fgf23-mediated hypophosphatemic rickets. J. Bone Miner. Res. 2013, 28, 899-911. [CrossRef]

151. Huqun; Izumi, S.; Miyazawa, H.; Ishii, K.; Uchiyama, B.; Ishida, T.; Tanaka, S.; Tazawa, R.; Fukuyama, S.; Tanaka, T.; et al. Mutations in the slc34a2 gene are associated with pulmonary alveolar microlithiasis. Am. J. Respir. Crit. Care Med. 2007, 175, 263-268. [CrossRef]

152. Corut, A.; Senyigit, A.; Ugur, S.A.; Altin, S.; Ozcelik, U.; Calisir, H.; Yildirim, Z.; Gocmen, A.; Tolun, A. Mutations in SLC34A2 Cause Pulmonary Alveolar Microlithiasis and Are Possibly Associated with Testicular Microlithiasis. Am. J. Hum. Genet. 2006, 79, 650-656. [CrossRef] [PubMed]

153. Tiosano, D.; Gepstein, V. Vitamin D action: Lessons learned from hereditary 1,25-dihydroxyvitamin-d-resistant rickets patients. Curr. Opin. Endocrinol. Diabetes Obes. 2012, 19, 452-459. [CrossRef] [PubMed]

154. Durmaz, E.; Zou, M.; Al-Rijjal, R.A.; Bircan, I.; Akçurin, S.; Meyer, B.; Shi, Y. Clinical and genetic analysis of patients with vitamin d-dependent rickets type 1a. Clin. Endocrinol. 2012, 77, 363-369. [CrossRef] [PubMed]

155. Christov, M.; Jüppner, H. Phosphate homeostasis disorders. Best Pract. Res. Clin. Endocrinol. Metab. 2018, 32, 685-706. [CrossRef] [PubMed]

156. Topaz, O.; Shurman, D.L.; Bergman, R.; Indelman, M.; Ratajczak, P.; Mizrachi, M.; Khamaysi, Z.; Behar, D.; Petronius, D.; Friedman, V.; et al. Mutations in galnt3, encoding a protein involved in o-linked glycosylation, cause familial tumoral calcinosis. Nat. Genet. 2004, 36, 579. [CrossRef] [PubMed]

157. Frishberg, Y.; Araya, K.; Rinat, C.; Topaz, O.; Yamazaki, Y.; Feinstein, Y.; Navon-Elkan, P.; Becker-Cohen, R.; Yamashita, T.; Igarashi, T.; et al. Hyperostosis-Hyperphosphatemia Syndrome Caused by Mutations in Galnt3 and Associated with Augmented Processing of fgf-23; American Society of Nephrology: Philadelphia, PA, USA, 2004; p. F-P0937.

158. Benet-Pages, A.; Orlik, P.; Strom, T.M.; Lorenz-Depiereux, B. An fgf23 missense mutation causes familial tumoral calcinosis with hyperphosphatemia. Hum. Mol. Genet. 2005, 14, 385-390. [CrossRef]

159. Ichikawa, S.; Sorenson, A.H.; Imel, E.A.; Friedman, N.E.; Gertner, J.M.; Econs, M.J. Intronic deletions in the slc34a3 gene cause hereditary hypophosphatemic rickets with hypercalciuria. J. Clin. Endocrinol. Metab. 2006, 91, 4022-4027. [CrossRef]

160. Ichikawa, S.; Imel, E.A.; Kreiter, M.L.; Yu, X.; Mackenzie, D.S.; Sorenson, A.H.; Goetz, R.; Mohammadi, M.; White, K.E.; Econs, M.J. A homozygous missense mutation in human klotho causes severe tumoral calcinosis. J. Clin. Investig. 2007, 117, 2684-2691. [CrossRef]

161. Mankin, H.J. Hyperphosphatasia, idiopathic. In Encyclopedia of Molecular Mechanisms of Disease; Lang, F., Ed.; Springer: Berlin/Heidelberg, Germany, 2009; pp. 926-927.

162. Weinstein, L.S.; Gejman, P.V.; de Mazancourt, P.; American, N.; Spiegel, A.M. A heterozygous 4-bp deletion mutation in the gs alpha gene (gnas1) in a patient with albright hereditary osteodystrophy. Genomics 1992, 13, 1319-1321. [CrossRef]

163. Juppner, H.; Schipani, E.; Bastepe, M.; Cole, D.E.; Lawson, M.L.; Mannstadt, M.; Hendy, G.N.; Plotkin, H.; Koshiyama, H.; Koh, T.; et al. The gene responsible for pseudohypoparathyroidism type ib is paternally imprinted and maps in four unrelated kindreds to chromosome 20q13.3. Proc. Natl. Acad. Sci. USA 1998, 95, 11798-11803. [CrossRef]

164. Arnold, A.; Horst, S.A.; Gardella, T.J.; Baba, H.; Levine, M.A.; Kronenberg, H.M. Mutation of the signal peptide-encoding region of the preproparathyroid hormone gene in familial isolated hypoparathyroidism. J. Clin. Investig. 1990, 86, 1084-1087. [CrossRef]

165. Pollak, M.R.; Brown, E.M.; Estep, H.L.; McLaine, P.N.; Kifor, O.; Park, J.; Hebert, S.C.; Seidman, C.E.; Seidman, J.G. Autosomal dominant hypocalcaemia caused by a $\mathrm{Ca}^{2+}$-sensing receptor gene mutation. Nat. Genet. 1994, 8, 303-307. [CrossRef] [PubMed] 
166. Ding, C.; Buckingham, B.; Levine, M.A. Familial isolated hypoparathyroidism caused by a mutation in the gene for the transcription factor gcmb. J. Clin. Investig. 2001, 108, 1215-1220. [CrossRef] [PubMed]

167. Zhang, P.; Jobert, A.S.; Couvineau, A.; Silve, C. A homozygous inactivating mutation in the parathyroid hormone/parathyroid hormone-related peptide receptor causing blomstrand chondrodysplasia. J. Clin. Endocrinol. Metab. 1998, 83, 3365-3368. [CrossRef] [PubMed]

168. Karperien, M.C.; van der Harten, H.J.; van Schooten, R.; Farih-Sips, H.; den Hollander, N.S.; Kneppers, A.L.J.; Nijweide, P.; Papapoulos, S.E.; Löwik, C.W.G.M. A frame-shift mutation in the type i parathyroid hormone/parathyroid hormone-related peptide receptor causing blomstrand lethal osteochondrodysplasia. J. Clin. Endocrinol. Metab. 1999, 84, 3713-3720. [CrossRef] [PubMed]

169. HYP-Consortium. A gene (pex) with homologies to endopeptidases is mutated in patients with $\mathrm{x}$-linked hypophosphatemic rickets. Nat. Genet. 1995, 11, 130-136. [CrossRef]

170. ADHR Consortium. Autosomal dominant hypophosphataemic rickets is associated with mutations in fgf 23 . Nat. Genet. 2000, 26, 345-348. [CrossRef]

171. Brownstein, C.A.; Adler, F.; Nelson-Williams, C.; Iijima, J.; Li, P.; Imura, A.; Nabeshima, Y.; Reyes-Mugica, M.; Carpenter, T.O.; Lifton, R.P. A translocation causing increased alpha-klotho level results in hypophosphatemic rickets and hyperparathyroidism. Proc. Natl. Acad. Sci. USA 2008, 105, 3455-3460. [CrossRef]

172. Lorenz-Depiereux, B.; Bastepe, M.; Benet-Pages, A.; Amyere, M.; Wagenstaller, J.; Muller-Barth, U.; Badenhoop, K.; Kaiser, S.M.; Rittmaster, R.S.; Shlossberg, A.H.; et al. Dmp1 mutations in autosomal recessive hypophosphatemia implicate a bone matrix protein in the regulation of phosphate homeostasis. Nat. Genet. 2006, 38, 1248-1250. [CrossRef]

173. Lorenz-Depiereux, B.; Schnabel, D.; Tiosano, D.; Häusler, G.; Strom, T.M. Loss-of-function enpp1 mutations cause both generalized arterial calcification of infancy and autosomal-recessive hypophosphatemic rickets. Am. J. Hum. Genet. 2010, 86, 267-272. [CrossRef]

174. Rafaelsen, S.H.; Ræder, H.; Fagerheim, A.K.; Knappskog, P.; Carpenter, T.O.; Johansson, S.; Bjerknes, R. Exome sequencing reveals fam $20 \mathrm{c}$ mutations associated with fibroblast growth factor 23-related hypophosphatemia, dental anomalies, and ectopic calcification. J. Bone Miner. Res. 2013, 28, 1378-1385. [CrossRef] [PubMed]

175. Lorenz-Depiereux, B.; Benet-Pages, A.; Eckstein, G.; Tenenbaum-Rakover, Y.; Wagenstaller, J.; Tiosano, D.; Gershoni-Baruch, R.; Albers, N.; Lichtner, P.; Schnabel, D.; et al. Hereditary hypophosphatemic rickets with hypercalciuria is caused by mutations in the sodium-phosphate cotransporter gene slc34a3. Am. J. Hum. Genet. 2006, 78, 193-201. [CrossRef] [PubMed]

176. Bergwitz, C.; Roslin, N.M.; Tieder, M.; Loredo-Osti, J.C.; Bastepe, M.; Abu-Zahra, H.; Frappier, D.; Burkett, K.; Carpenter, T.O.; Anderson, D.; et al. Slc34a3 mutations in patients with hereditary hypophosphatemic rickets with hypercalciuria predict a key role for the sodium-phosphate cotransporter napi-iic in maintaining phosphate homeostasis. Am. J. Hum. Genet. 2006, 78, 179-192. [CrossRef] [PubMed]

177. Kitanaka, S.; Takeyama, K.; Murayama, A.; Sato, T.; Okumura, K.; Nogami, M.; Hasegawa, Y.; Niimi, H.; Yanagisawa, J.; Tanaka, T.; et al. Inactivating mutations in the 25-hydroxyvitamin d3 1alpha-hydroxylase gene in patients with pseudovitamin d-deficiency rickets. N. Engl. J. Med. 1998, 338, 653-661. [CrossRef] [PubMed]

178. Hughes, M.R.; Malloy, P.J.; Kieback, D.G.; Kesterson, R.A.; Pike, J.W.; Feldman, D.; O’Malley, B.W. Point mutations in the human vitamin d receptor gene associated with hypocalcemic rickets. Science 1988, 242, 1702-1705. [CrossRef]

179. Pollak, M.R.; Brown, E.M.; WuChou, Y.H.; Hebert, S.C.; Marx, S.J.; Steinmann, B.; Levi, T.; Seidman, C.E.; Seidman, J.G. Mutations in the human $\mathrm{Ca}^{2+}$-sensing receptor gene cause familial hypocalciuric hypercalcemia and neonatal severe hyperparathyroidism. Cell 1993, 75, 1297-1303. [CrossRef]

180. Schipani, E.; Kruse, K.; Juppner, H. A constitutively active mutant pth-pthrp receptor in jansen-type metaphyseal chondrodysplasia. Science 1995, 268, 98-100. [CrossRef]

181. Brown, W.W.; Juppner, H.; Langman, C.B.; Price, H.; Farrow, E.G.; White, K.E.; McCormick, K.L. Hypophosphatemia with elevations in serum fibroblast growth factor 23 in a child with jansen's metaphyseal chondrodysplasia. J. Clin. Endocrinol. Metab. 2009, 94, 17-20. [CrossRef]

182. Topaz, O.; Indelman, M.; Chefetz, I.; Geiger, D.; Metzker, A.; Altschuler, Y.; Choder, M.; Bercovich, D.; Uitto, J.; Bergman, R.; et al. A deleterious mutation in samd9 causes normophosphatemic familial tumoral calcinosis. Am. J. Hum. Genet. 2006, 79, 759-764. [CrossRef] 
183. Bhoj, E.J.; Li, M.; Ahrens-Nicklas, R.; Pyle, L.C.; Wang, J.; Zhang, V.W.; Clarke, C.; Wong, L.J.; Sondheimer, N.; Ficicioglu, C.; et al. Pathologic variants of the mitochondrial phosphate carrier slc25a3: Two new patients and expansion of the cardiomyopathy/skeletal myopathy phenotype with and without lactic acidosis. JIMD Rep. 2015, 19, 59-66.

184. Mayr, J.A.; Zimmermann, F.A.; Horvath, R.; Schneider, H.C.; Schoser, B.; Holinski-Feder, E.; Czermin, B.; Freisinger, P.; Sperl, W. Deficiency of the mitochondrial phosphate carrier presenting as myopathy and cardiomyopathy in a family with three affected children. Neuromuscul. Disord. 2011, 21, 803-808. [CrossRef]

185. Lemos, R.R.; Ramos, E.M.; Legati, A.; Nicolas, G.; Jenkinson, E.M.; Livingston, J.H.; Crow, Y.J.; Campion, D.; Coppola, G.; Oliveira, J.R.M. Update and mutational analysis of slc20a2: A major cause of primary familial brain calcification. Hum. Mutat. 2015, 36, 489-495. [CrossRef] [PubMed]

186. Keller, A.; Westenberger, A.; Sobrido, M.J.; García-Murias, M.; Domingo, A.; Sears, R.L.; Lemos, R.R.; Ordoñez-Ugalde, A.; Nicolas, G.; da Cunha, J.E.G.; et al. Mutations in the gene encoding pdgf-b cause brain calcifications in humans and mice. Nat. Genet. 2013, 45, 1077. [CrossRef] [PubMed]

187. Legati, A.; Giovannini, D.; Nicolas, G.; Lopez-Sanchez, U.; Quintans, B.; Oliveira, J.R.; Sears, R.L.; Ramos, E.M.; Spiteri, E.; Sobrido, M.J.; et al. Mutations in xpr1 cause primary familial brain calcification associated with altered phosphate export. Nat. Genet. 2015, 47, 579-581. [CrossRef] [PubMed]

188. Yao, X.-P.; Cheng, X.; Wang, C.; Zhao, M.; Guo, X.-X.; Su, H.-Z.; Lai, L.-L.; Zou, X.-H.; Chen, X.-J.; Zhao, Y.; et al. Biallelic mutations in myorg cause autosomal recessive primary familial brain calcification. Neuron 2018, 98, 1116-1123.e1115. [CrossRef] [PubMed]

189. Grangeon, L.; Wallon, D.; Charbonnier, C.; Quenez, O.; Richard, A.-C.; Rousseau, S.; Budowski, C.; Lebouvier, T.; Corbille, A.-G.; Vidailhet, M.; et al. Biallelic myorg mutation carriers exhibit primary brain calcification with a distinct phenotype. Brain 2019, 142, 1573-1586. [CrossRef]

190. Cen, Z.; Chen, Y.; Chen, S.; Wang, H.; Yang, D.; Zhang, H.; Wu, H.; Wang, L.; Tang, S.; Ye, J.; et al. Biallelic loss-of-function mutations in jam2 cause primary familial brain calcification. Brain 2019, 143, 491-502. [CrossRef]

191. Schottlaender, L.V.; Abeti, R.; Jaunmuktane, Z.; Macmillan, C.; Chelban, V.; O'Callaghan, B.; McKinley, J.; Maroofian, R.; Efthymiou, S.; Athanasiou-Fragkouli, A.; et al. Bi-allelic jam2 variants lead to early-onset recessive primary familial brain calcification. Am. J. Hum. Genet. 2020, 106, 412-421. [CrossRef]

192. Michigami, T.; Kawai, M.; Yamazaki, M.; Ozono, K. Phosphate as a signaling molecule and its sensing mechanism. Physiol. Rev. 2018, 98, 2317-2348. [CrossRef]

193. Beck, L.; Beck-Cormier, S. Extracellular phosphate sensing in mammals: What do we know? J. Mol. Endocrinol. 2020, 65, R53-R63. [CrossRef]

194. Chavkin, N.W.; Chia, J.J.; Crouthamel, M.H.; Giachelli, C.M. Phosphate uptake-independent signaling functions of the type iii sodium-dependent phosphate transporter, pit-1, in vascular smooth muscle cells. Exp. Cell Res. 2015, 333, 39-48. [CrossRef] [PubMed]

195. Beck, L.; Leroy, C.; Salaun, C.; Margall-Ducos, G.; Desdouets, C.; Friedlander, G. Identification of a novel function of pit1 critical for cell proliferation and independent of its phosphate transport activity. J. Biol. Chem. 2009, 284, e99959. [CrossRef] [PubMed]

196. Geng, Y.; Mosyak, L.; Kurinov, I.; Zuo, H.; Sturchler, E.; Cheng, T.C.; Subramanyam, P.; Brown, A.P.; Brennan, S.C.; Mun, H.C.; et al. Structural mechanism of ligand activation in human calcium-sensing receptor. eLife 2016, 5. [CrossRef] [PubMed]

197. Centeno, P.P.; Herberger, A.; Mun, H.-C.; Tu, C.; Nemeth, E.F.; Chang, W.; Conigrave, A.D.; Ward, D.T. Phosphate acts directly on the calcium-sensing receptor to stimulate parathyroid hormone secretion. Nat. Commun. 2019, 10, 4693. [CrossRef]

198. Giovannini, D.; Touhami, J.; Charnet, P.; Sitbon, M.; Battini, J.-L. Inorganic phosphate export by the retrovirus receptor xpr1 in metazoans. Cell Rep. 2013, 3, 1866-1873. [CrossRef]

199. Wild, R.; Gerasimaite, R.; Jung, J.-Y.; Truffault, V.; Pavlovic, I.; Schmidt, A.; Saiardi, A.; Jessen, H.J.; Poirier, Y.; Hothorn, M.; et al. Control of eukaryotic phosphate homeostasis by inositol polyphosphate sensor domains. Science 2016, 352, 986-990. [CrossRef]

200. Wilson, M.S.; Jessen, H.J.; Saiardi, A. The inositol hexakisphosphate kinases ip6k1 and -2 regulate human cellular phosphate homeostasis, including xpr1-mediated phosphate export. J. Biol. Chem. 2019, 294, 11597-11608. [CrossRef] [PubMed] 
201. Li, X.; Gu, C.; Hostachy, S.; Sahu, S.; Wittwer, C.; Jessen, H.J.; Fiedler, D.; Wang, H.; Shears, S.B. Control of xpr1-dependent cellular phosphate efflux by insp8 is an exemplar for functionally-exclusive inositol pyrophosphate signaling. Proc. Natl. Acad. Sci. USA 2020, 117, 3568-3574. [CrossRef]

202. Bergwitz, C.; Rasmussen, M.D.; Derobertis, C.; Wee, M.J.; Sinha, S.; Chen, H.H.; Huang, J.; Perrimon, N. Roles of major facilitator superfamily transporters in phosphate response in drosophila. PLoS ONE 2012, 7, e31730. [CrossRef]

203. Wittrant, Y.; Bourgine, A.; Khoshniat, S.; Alliot-Licht, B.; Masson, M.; Gatius, M.; Rouillon, T.; Weiss, P.; Beck, L.; Guicheux, J. Inorganic phosphate regulates glvr-1 and -2 expression: Role of calcium and erk1/2. Biochem. Biophys. Res. Commun. 2009, 381, 259-263. [CrossRef]

204. Bon, N.; Couasnay, G.; Bourgine, A.; Sourice, S.; Beck-Cormier, S.; Guicheux, J.A.-O.; Beck, L.A.-O. Phosphate (P(i))-regulated heterodimerization of the high-affinity sodium-dependent $\mathrm{P}(\mathrm{i})$ transporters PiT1/Slc20a1 and PiT2/Slc20a2 underlies extracellular P(i) sensing independently of P(i) uptake. J. Biol. Chem. 2018, 293, 2102-2214. [CrossRef] [PubMed]

205. Ha, S.-W.; Jang, H.L.; Nam, K.T.; Beck, G.R. Nano-hydroxyapatite modulates osteoblast lineage commitment by stimulation of DNA methylation and regulation of gene expression. Biomaterials 2015, 65, 32-42. [CrossRef] [PubMed]

206. Ha, S.-W.; Park, J.; Habib, M.M.; Beck, G.R. Nano-hydroxyapatite stimulation of gene expression requires fgf receptor, phosphate transporter, and erk1/2 signaling. ACS Appl. Mater. Interfaces 2017, 9, 39185-39196. [CrossRef] [PubMed]

207. Takashi, Y.; Kosako, H.; Sawatsubashi, S.; Kinoshita, Y.; Ito, N.; Tsoumpra, M.K.; Nangaku, M.; Abe, M.; Matsuhisa, M.; Kato, S.; et al. Activation of unliganded fgf receptor by extracellular phosphate potentiates proteolytic protection of fgf 23 by its o-glycosylation. Proc. Natl. Acad. Sci. USA 2019, 116, 11418. [CrossRef] [PubMed]

208. Furdui, C.M.; Lew, E.D.; Schlessinger, J.; Anderson, K.S. Autophosphorylation of fgfr1 kinase is mediated by a sequential and precisely ordered reaction. Mol. Cell 2006, 21,711-717. [CrossRef]

209. Lew, E.D.; Furdui, C.M.; Anderson, K.S.; Schlessinger, J. The precise sequence of fgf receptor autophosphorylation is kinetically driven and is disrupted by oncogenic mutations. Sci. Signal. 2009, 2, ra6. [CrossRef]

210. Brown, E.M.; Gamba, G.; Riccardi, D.; Lombardi, M.; Butters, R.; Kifor, O.; Sun, A.; Hediger, M.A.; Lytton, J.; Hebert, S.C. Cloning and characterization of an extracellular $\mathrm{Ca}(2+)$-sensing receptor from bovine parathyroid. Nature 1993, 366, 575-580. [CrossRef]

211. López-Sánchez, U.; Tury, S.; Nicolas, G.; Wilson, M.S.; Jurici, S.; Ayrignac, X.; Courgnaud, V.; Saiardi, A.; Sitbon, M.; Battini, J.-L. Interplay between pfbc-associated slc20a2 and xpr1 phosphate transporters requires inositol polyphosphates for control of cellular phosphate homeostasis. J. Biol. Chem. 2020. [CrossRef]

212. Pauleau, A.L.; Galluzzi, L.; Scholz, S.R.; Larochette, N.; Kepp, O.; Kroemer, G. Unexpected role of the phosphate carrier in mitochondrial fragmentation. Cell Death Differ. 2008, 15, 616. [CrossRef]

213. Seifert, E.L.; Ligeti, E.; Mayr, J.A.; Sondheimer, N.; Hajnoczky, G. The mitochondrial phosphate carrier: Role in oxidative metabolism, calcium handling and mitochondrial disease. Biochem. Biophys. Res. Commun. 2015, 464, 369-375. [CrossRef]

214. Greig Couasnay, N.B.; Claire-Sophie, D.; Sophie, S.; Arnaud, B.; Joelle, V.; Pierre, W.; Sylvain, P.; Jerome, G.; Sarah, B.-C.; Laurent, B. Pit1/slc20a1-Mediated Endoplasmic Reticulum Homeostasis and Cell Survival in Growth Plate Chondrocytes; ASBMR: Denver, CO, USA, 2017.

215. Laver, D.R.; Lenz, G.K.E.; Dulhunty, A.F. Phosphate ion channels in sarcoplasmic reticulum of rabbit skeletal muscle. J. Physiol. 2001, 535, 715-728. [CrossRef] [PubMed]

216. Itoh, H.; Takahashi, A.; Adachi, K.; Noji, H.; Yasuda, R.; Yoshida, M.; Kinosita, K., Jr. Mechanically driven atp synthesis by f1-atpase. Nature 2004, 427, 465. [CrossRef] [PubMed]

217. Pesta, D.H.; Tsirigotis, D.N.; Befroy, D.E.; Caballero, D.; Jurczak, M.J.; Rahimi, Y.; Cline, G.W.; Dufour, S.; Birkenfeld, A.L.; Rothman, D.L.; et al. Hypophosphatemia promotes lower rates of muscle atp synthesis. FASEB J. 2016, 30, 3378-3387. [CrossRef] [PubMed]

218. Hardie, D.G.; Ross, F.A.; Hawley, S.A. Ampk: A nutrient and energy sensor that maintains energy homeostasis. Nat. Rev. Mol. Cell Biol. 2012, 13, 251-262. [CrossRef]

219. Jeon, S.-M. Regulation and function of ampk in physiology and diseases. Exp. Mol. Med. 2016, 48, e245. [CrossRef] [PubMed] 
220. Nina Bon, A.B.; Greig, C.; Sophie, S.; Jérôme, G.; Sarah, B.-C.; Laurent, B. Pivotal Role of pit1/slc20a1 and pit2/slc20a2 in Phosphate-Dependent mapk/erk1/2 Signaling and fgf23 Secretion in Bone; ASBMR: Denver, CO, USA, 2017.

221. Gorvin, C.M. Insights into calcium-sensing receptor trafficking and biased signalling by studies of calcium homeostasis. J. Mol. Endocrinol. 2018, 61, R1-R12. [CrossRef]

222. Koyama, Y.; Rittling, S.; Tsuji, K.; Hino, K.; Salincarnboriboon, R.; Yano, T.; Taketani, Y.; Nifuji, A.; Denhardt, D.T.; Noda, M. Osteopontin deficiency suppresses high phosphate load-induced bone loss via specific modulation of osteoclasts. Endocrinology 2006, 147, 3040-3049. [CrossRef] [PubMed]

223. Beck, G.R., Jr.; Zerler, B.; Moran, E. Phosphate is a specific signal for induction of osteopontin gene expression. Proc. Natl. Acad. Sci. USA 2000, 97, 8352-8357. [CrossRef]

224. Giachelli, C.M. Vascular calcification: In vitro evidence for the role of inorganic phosphate. J. Am. Soc. Nephrol. 2003, 14, S300-S304. [CrossRef] [PubMed]

225. Shobeiri, N.; Adams, M.A.; Holden, R.M. Phosphate: An old bone molecule but new cardiovascular risk factor. Br. J. Clin. Pharmacol. 2014, 77, 39-54. [CrossRef]

226. Krabbe, S.; Christiansen, C.; Rødbro, P.; Transbøl, I. Effect of puberty on rates of bone growth and mineralisation: With observations in male delayed puberty. Arch. Dis. Child. 1979, 54, 950-953. [CrossRef] [PubMed]

227. Follet, H.; Boivin, G.; Rumelhart, C.; Meunier, P.J. The degree of mineralization is a determinant of bone strength: A study on human calcanei. Bone 2004, 34, 783-789. [CrossRef] [PubMed]

228. Oryan, A.; Monazzah, S.; Bigham-Sadegh, A. Bone injury and fracture healing biology. Biomed. Environ. Sci 2015, 28, 57-71.

229. Anderson, H.C. Molecular biology of matrix vesicles. Clin. Orthop. Relat. Res. 1995, 266-280. [CrossRef]

230. Anderson, H.C. Matrix vesicles and calcification. Curr. Rheumatol. Rep. 2003, 5, 222-226. [CrossRef]

231. Bottini, M.; Mebarek, S.; Anderson, K.L.; Strzelecka-Kiliszek, A.; Bozycki, L.; Simao, A.M.S.; Bolean, M.; Ciancaglini, P.; Pikula, J.B.; Pikula, S.; et al. Matrix vesicles from chondrocytes and osteoblasts: Their biogenesis, properties, functions and biomimetic models. Biochim. Biophys. Acta Gen. Subj. 2018, 1862, 532-546. [CrossRef]

232. Hoac, B.; Kiffer-Moreira, T.; Millán, J.L.; McKee, M.D. Polyphosphates inhibit extracellular matrix mineralization in mc3t3-e1 osteoblast cultures. Bone 2013, 53, 478-486. [CrossRef]

233. Terkeltaub, R.A. Inorganic pyrophosphate generation and disposition in pathophysiology. Am. J. Physiol. Cell Physiol. 2001, 281, C1-C11. [CrossRef]

234. Hessle, L.; Johnson, K.A.; Anderson, H.C.; Narisawa, S.; Sali, A.; Goding, J.W.; Terkeltaub, R.; Millan, J.L. Tissue-nonspecific alkaline phosphatase and plasma cell membrane glycoprotein-1 are central antagonistic regulators of bone mineralization. Proc. Natl. Acad. Sci. USA 2002, 99, 9445-9449. [CrossRef]

235. Tiosano, D.; Hochberg, Z. Hypophosphatemia: The common denominator of all rickets. J. Bone Miner. Metab. 2009, 27, 392-401. [CrossRef]

236. Mozar, A.; Haren, N.; Chasseraud, M.; Louvet, L.; Maziere, C.; Wattel, A.; Mentaverri, R.; Morliere, P.; Kamel, S.; Brazier, M.; et al. High extracellular inorganic phosphate concentration inhibits rank-rankl signaling in osteoclast-like cells. J. Cell Physiol. 2008, 215, 47-54. [CrossRef] [PubMed]

237. Kanatani, M.; Sugimoto, T.; Kano, J.; Kanzawa, M.; Chihara, K. Effect of high phosphate concentration on osteoclast differentiation as well as bone-resorbing activity. J. Cell Physiol. 2003, 196, 180-189. [CrossRef] [PubMed]

238. Takeda, E.; Yamamoto, H.; Taketani, Y.; Yamanaka-Okumura, H. Dietary phosphorus in bone health and quality of life. Nutr. Rev. 2012, 70, 311-321. [CrossRef]

239. Cozzolino, M.; Pasho, S.; Fallabrino, G.; Olivi, L.; Gallieni, M.; Brancaccio, D. Pathogenesis of secondary hyperparathyroidism. Int. J. Artif. Organs. 2009, 32, 75-80. [CrossRef] [PubMed]

240. Krishnarao, G.V.G.; Draper, H.H. Influence of dietary phosphate on bone resorption in senescent mice. J. Nutr. 1972, 102, 1143-1145. [CrossRef] [PubMed]

241. Pinheiro, M.M.; Schuch, N.J.; Genaro, P.S.; Ciconelli, R.M.; Ferraz, M.B.; Martini, L.A. Nutrient intakes related to osteoporotic fractures in men and women-The Brazilian Osteoporosis Study (BRAZOS). Nutr. J. 2009, 8, 6. [CrossRef] [PubMed]

242. Murali, S.K.; Roschger, P.; Zeitz, U.; Klaushofer, K.; Andrukhova, O.; Erben, R.G. Fgf23 regulates bone mineralization in a 1,25(oh) $2 \mathrm{~d} 3$ and klotho-independent manner. J. Bone Miner. Res. 2016, 31, 129-142. [CrossRef]

243. Erben, R.G. Physiological actions of fibroblast growth factor-23. Front. Endocrinol. 2018, 9, 267. [CrossRef] 
244. Orfanidou, T.; Malizos, K.N.; Varitimidis, S.; Tsezou, A. 1,25-dihydroxyvitamin d(3) and extracellular inorganic phosphate activate mitogen-activated protein kinase pathway through fibroblast growth factor 23 contributing to hypertrophy and mineralization in osteoarthritic chondrocytes. Exp. Biol. Med. 2012, 237, 241-253. [CrossRef]

245. Liu, E.S.; Zalutskaya, A.; Chae, B.T.; Zhu, E.D.; Gori, F.; Demay, M.B. Phosphate interacts with pthrp to regulate endochondral bone formation. Endocrinology 2014, 155, 3750-3756. [CrossRef]

246. Papaioannou, G.; Petit, E.T.; Liu, E.S.; Baccarini, M.; Pritchard, C.; Demay, M.B. Raf kinases are essential for phosphate induction of erk1/2 phosphorylation in hypertrophic chondrocytes and normal endochondral bone development. J. Biol. Chem. 2017, 292, 3164-3171. [CrossRef] [PubMed]

247. Wang, D.; Canaff, L.; Davidson, D.; Corluka, A.; Liu, H.; Hendy, G.N.; Henderson, J.E. Alterations in the sensing and transport of phosphate and calcium by differentiating chondrocytes. J. Biol. Chem. 2001, 276, 33995-34005. [CrossRef] [PubMed]

248. Teixeira, C.C.; Mansfield, K.; Hertkorn, C.; Ischiropoulos, H.; Shapiro, I.M. Phosphate-induced chondrocyte apoptosis is linked to nitric oxide generation. Am. J. Physiol. Cell Physiol. 2001, 281, C833-C839. [CrossRef] [PubMed]

249. Civitelli, R. Cell-cell communication in the osteoblast/osteocyte lineage. Arch. Biochem. Biophys. 2008, 473, 188-192. [CrossRef]

250. Staines, K.A.; MacRae, V.E.; Farquharson, C. The importance of the sibling family of proteins on skeletal mineralisation and bone remodelling. J. Endocrinol. 2012, 214, 241-255. [CrossRef]

251. Bellido, T. Osteocyte-driven bone remodeling. Calcif. Tissue Int. 2014, 94, 25-34. [CrossRef] [PubMed]

252. Conrads, K.A.; Yu, L.R.; Lucas, D.A.; Zhou, M.; Chan, K.C.; Simpson, K.A.; Schaefer, C.F.; Issaq, H.J.; Veenstra, T.D.; Beck, G.R., Jr.; et al. Quantitative proteomic analysis of inorganic phosphate-induced murine mc3t3-e1 osteoblast cells. Electrophoresis 2004, 25, 1342-1352. [CrossRef]

253. Conrads, K.A.; Yi, M.; Simpson, K.A.; Lucas, D.A.; Camalier, C.E.; Yu, L.R.; Veenstra, T.D.; Stephens, R.M.; Conrads, T.P.; Beck, G.R., Jr. A combined proteome and microarray investigation of inorganic phosphate-induced pre-osteoblast cells. Mol. Cell Proteom. 2005, 4, 1284-1296. [CrossRef]

254. Kanatani, M.; Sugimoto, T.; Kano, J.; Chihara, K. Igf-i mediates the stimulatory effect of high phosphate concentration on osteoblastic cell proliferation. J. Cell Physiol. 2002, 190, 306-312. [CrossRef]

255. Julien, M.; Khoshniat, S.; Lacreusette, A.; Gatius, M.; Bozec, A.; Wagner, E.F.; Wittrant, Y.; Masson, M.; Weiss, P.; Beck, L.; et al. Phosphate-dependent regulation of mgp in osteoblasts: Role of erk1/2 and fra-1. J. Bone Miner. Res. 2009, 24, 1856-1868. [CrossRef]

256. Ito, N.; Findlay, D.M.; Anderson, P.H.; Bonewald, L.F.; Atkins, G.J. Extracellular phosphate modulates the effect of 1alpha,25-dihydroxy vitamin d3 (1,25d) on osteocyte like cells. J. Steroid. Biochem. Mol. Biol. 2013, 136, 183-186. [CrossRef] [PubMed]

257. Capulli, M.; Paone, R.; Rucci, N. Osteoblast and osteocyte: Games without frontiers. Arch. Biochem. Biophys. 2014, 561, 3-12. [CrossRef] [PubMed]

258. Dallas, S.L.; Prideaux, M.; Bonewald, L.F. The osteocyte: An endocrine cell. And more. Endocr Rev. 2013, 34 , 658-690. [CrossRef] [PubMed]

259. Nakashima, K.; de Crombrugghe, B. Transcriptional mechanisms in osteoblast differentiation and bone formation. Trends Genet. 2003, 19, 458-466. [CrossRef]

260. Bourgine, A.; Pilet, P.; Diouani, S.; Sourice, S.; Lesoeur, J.; Beck-Cormier, S.; Khoshniat, S.; Weiss, P.; Friedlander, G.; Guicheux, J.; et al. Mice with hypomorphic expression of the sodium-phosphate cotransporter pit1/slc20a1 have an unexpected normal bone mineralization. PLoS ONE 2013, 8, e65979. [CrossRef]

261. Teitelbaum, S.L. Bone resorption by osteoclasts. Science 2000, 289, 1504-1508. [CrossRef]

262. Albano, G.; Moor, M.; Dolder, S.; Siegrist, M.; Wagner, C.A.; Biber, J.; Hernando, N.; Hofstetter, W.; Bonny, O.; Fuster, D.G. Sodium-dependent phosphate transporters in osteoclast differentiation and function. PLoS ONE 2015, 10, e0125104. [CrossRef]

263. Yates, A.J.; Oreffo, R.O.; Mayor, K.; Mundy, G.R. Inhibition of bone resorption by inorganic phosphate is mediated by both reduced osteoclast formation and decreased activity of mature osteoclasts. J. Bone Miner. Res. 1991, 6, 473-478. [CrossRef]

264. M’Baya-Moutoula, E.; Louvet, L.; Metzinger-Le Meuth, V.; Massy, Z.A.; Metzinger, L. High inorganic phosphate concentration inhibits osteoclastogenesis by modulating mir-223. Biochim. Biophys. Acta 2015, 1852, 2202-2212. [CrossRef] 
265. Beck, L.; Karaplis, A.C.; Amizuka, N.; Hewson, A.S.; Ozawa, H.; Tenenhouse, H.S. Targeted inactivation of npt2 in mice leads to severe renal phosphate wasting, hypercalciuria, and skeletal abnormalities. Proc. Natl. Acad. Sci. USA 1998, 95, 5372-5377. [CrossRef]

266. Hayashibara, T.; Hiraga, T.; Sugita, A.; Wang, L.; Hata, K.; Ooshima, T.; Yoneda, T. Regulation of osteoclast differentiation and function by phosphate: Potential role of osteoclasts in the skeletal abnormalities in hypophosphatemic conditions. J. Bone Miner. Res. 2007, 22, 1743-1751. [CrossRef] [PubMed]

267. Gupta, A.; Guo, X.L.; Alvarez, U.M.; Hruska, K.A. Regulation of sodium-dependent phosphate transport in osteoclasts. J. Clin. Investig. 1997, 100, 538-549. [CrossRef] [PubMed]

268. Li, G.; Miura, K.; Kuno, M. Extracellular phosphates enhance activities of voltage-gated proton channels and production of reactive oxygen species in murine osteoclast-like cells. Pflug. Arch. 2017, 469, 279-292. [CrossRef] [PubMed]

269. Nanci, A. Ten Cate's Oral Histology-E-Book: Development, Structure, and Function; Elsevier Health Sciences: Amsterdam, The Netherlands, 2017.

270. Abou Neel, E.A.; Aljabo, A.; Strange, A.; Ibrahim, S.; Coathup, M.; Young, A.M.; Bozec, L.; Mudera, V. Demineralization-remineralization dynamics in teeth and bone. Int. J. Nanomed. 2016, 4743-4763. [CrossRef]

271. Dietary reference Intakes for Calcium, Phosphorus, Magnesium, Vitamin D, and Fluoride; National Academy of Sciences: Washington, DC, USA, 1997.

272. Gaunt, W.E.; Irving, J.T. The influence of dietary calcium and phosphorus upon tooth formation. J. Physiol. 1940, 99, 18-29. [CrossRef]

273. Ferguson, H.W.; Hartles, R.L. The effect of diets deficient in calcium or phosphorus in the presence and absence of supplements of vitamin d on the incisor teeth and bone of adult rats. Arch. Oral Biol. 1966, 11, 1345-IN31. [CrossRef]

274. Schour, S.; Massler, M. The effects of dietary deficiencies upon the oral structures. Am. J. Physiol. Physiol. Rev. 1945, 41.

275. Ferguson, H.W.; Hartles, R.L. The effect of vitamin $d$ on the dentine of the incisor teeth and on the alveolar bone of young rats maintained on diets deficient in calcium or phosphorus. Arch. Oral Biol. 1964, 9, 447-460. [CrossRef]

276. Becks, H.; Weber, M. The Influence of Diet on the Bone System with Special Reference to the Alveolar Process and the Labyrinthine Capsule. J. Am. Dent. Assoc. 1931, 18, 197-264.

277. Jekl, V.; Krejcirova, L.; Buchtova, M.; Knotek, Z. Effect of high phosphorus diet on tooth microstructure of rodent incisors. Bone 2011, 49, 479-484. [CrossRef]

278. Goodson, J.M.; Shi, P.; Mumena, C.H.; Haq, A.; Razzaque, M.S. Dietary phosphorus burden increases cariogenesis independent of vitamin d uptake. J. Steroid Biochem. Mol. Boil. 2017, 167, 33-38. [CrossRef] [PubMed]

279. Pollock, R.A.; Brown, T.W., Jr.; Rubin, D.M. "Phossy jaw" and "bis-phossy jaw" of the 19th and the 21st centuries: The diuturnity of john walker and the friction match. Craniomaxillofac Trauma Reconstr. 2015, 8, 262-270. [CrossRef] [PubMed]

280. Ruggiero, S.L.; Fantasia, J.; Carlson, E. Bisphosphonate-related osteonecrosis of the jaw: Background and guidelines for diagnosis, staging and management. Oral Surg. Oral Med. Oral Pathol. Oral Radiol. Endodontol. 2006, 102, 433-441. [CrossRef] [PubMed]

281. Merametdjian, L.; Beck-Cormier, S.; Bon, N.; Couasnay, G.; Sourice, S.; Guicheux, J.; Gaucher, C.; Beck, L. Expression of phosphate transporters during dental mineralization. J. Dent. Res. 2018, 97, 209-217. [CrossRef] [PubMed]

282. Tada, H.; Nemoto, E.; Foster, B.L.; Somerman, M.J.; Shimauchi, H. Phosphate increases bone morphogenetic protein-2 expression through camp-dependent protein kinase and erk1/2 pathways in human dental pulp cells. Bone 2011, 48, 1409-1416. [CrossRef]

283. Lundquist, P.; Ritchie, H.H.; Moore, K.; Lundgren, T.; Linde, A. Phosphate and calcium uptake by rat odontoblast-like mrpc-1 cells concomitant with mineralization. J. Bone Miner. Res. 2002, 17, 1801-1813. [CrossRef]

284. Beck, L. Expression and function of slc34 sodium-phosphate co-transporters in skeleton and teeth. Pflug. Arch. Eur. J. Physiol. 2019, 471, 175-184. [CrossRef]

285. Wright, J.T.; Carrion, I.A.; Morris, C. The molecular basis of hereditary enamel defects in humans. J. Dent. Res. 2014, 94, 52-61. [CrossRef] 
286. Antoniucci, D.M.; Yamashita, T.; Portale, A.A. Dietary phosphorus regulates serum fibroblast growth factor-23 concentrations in healthy men. J. Clin. Endocrinol. Metab. 2006, 91, 3144-3149. [CrossRef]

287. Coyac, B.R. Tissue-specific mineralization defects in the periodontium of the hyp mouse model of $x$-linked hypophosphatemia. Bone 2017, 103, 334-346. [CrossRef]

288. Turan, S.; Aydin, C.; Bereket, A.; Akcay, T.; Guran, T.; Yaralioglu, B.A.; Bastepe, M.; Juppner, H. Identification of a novel dentin matrix protein-1 (dmp-1) mutation and dental anomalies in a kindred with autosomal recessive hypophosphatemia. Bone 2010, 46, 402-409. [CrossRef] [PubMed]

289. Ariyoshi, N.; Nogi, M.; Ando, A.; Watanabe, H.; Umekawa, S. Hypophosphatemia-induced cardiomyopathy. Am. J. Med. Sci. 2016, 352, 317-323. [CrossRef]

290. Lichtman, M.A.; Miller, D.R.; Cohen, J.; Waterhouse, C. Reduced red cell glycolysis, 2, 3-diphosphoglycerate and adenosine triphosphate concentration, and increased hemoglobin-oxygen affinity caused by hypophosphatemia. Ann. Intern. Med. 1971, 74, 562-568. [CrossRef] [PubMed]

291. Ognibene, A.; Ciniglio, R.; Greifenstein, A.; Jarjoura, D.; Cugino, A.; Blend, D.; Whittier, F. Ventricular tachycardia in acute myocardial infarction: The role of hypophosphatemia. South. Med. J. 1994, 87, 65-69. [CrossRef] [PubMed]

292. Singhal, P.C.; Kumar, A.; Desroches, L.; Gibbons, N.; Mattana, J. Prevalence and predictors of rhabdomyolysis in patients with hypophosphatemia. Am. J. Med. 1992, 92, 458-464. [CrossRef]

293. Davis, S.V.; Olichwier, K.K.; Chakko, S.C. Reversible depression of myocardial performance in hypophosphatemia. Am. J. Med. Sci. 1988, 295, 183-187. [CrossRef]

294. Fuller, T.J.; Nichols, W.W.; Brenner, B.J.; Peterson, J.C. Reversible depression in myocardial performance in dogs with experimental phosphorus deficiency. J. Clin. Investig. 1978, 62, 1194-1200. [CrossRef]

295. Claudius, I.; Sachs, C.; Shamji, T. Hypophosphatemia-induced heart failure. Am. J. Emerg. Med. 2002, 20, 369-370. [CrossRef]

296. Neves, K.R.; Graciolli, F.G.; Dos Reis, L.M.; Pasqualucci, C.A.; MoysÉS, R.M.A.; Jorgetti, V. Adverse effects of hyperphosphatemia on myocardial hypertrophy, renal function, and bone in rats with renal failure. Kidney Int. 2004, 66, 2237-2244. [CrossRef]

297. Zhang, J.; Wang, N. Prognostic significance and therapeutic option of heart rate variability in chronic kidney disease. Int. Urol. Nephrol. 2014, 46, 19-25. [CrossRef]

298. Huang, J.C.; Kuo, I.C.; Tsai, Y.C.; Lee, J.J.; Lim, L.M.; Chen, S.C.; Chiu, Y.W.; Chang, J.M.; Chen, H. Heart rate variability predicts major adverse cardiovascular events and hospitalization in maintenance hemodialysis patients. Kidney Blood Press. Res. 2017, 42, 76-88. [CrossRef] [PubMed]

299. Wang, Q.; Cui, Y.; Yogendranath, P.; Wang, N. Blood pressure and heart rate variability are linked with hyperphosphatemia in chronic kidney disease patients. Chronobiol. Int. 2018, 35, 1329-1334. [CrossRef]

300. Sarafidis, P.A.; Ruilope, L.M.; Loutradis, C.; Gorostidi, M.; de la Sierra, A.; de la Cruz, J.J.; Vinyoles, E.; Divisón-Garrote, J.A.; Segura, J.; Banegas, J.R. Blood pressure variability increases with advancing chronic kidney disease stage: A cross-sectional analysis of 16546 hypertensive patients. J. Hypertens. 2018, 36, 1076-1085. [CrossRef] [PubMed]

301. London, G.M.; Guerin, A.P.; Marchais, S.J.; Metivier, F.; Pannier, B.; Adda, H. Arterial media calcification in end-stage renal disease: Impact on all-cause and cardiovascular mortality. Nephrol. Dial. Transpl. 2003, 18, 1731-1740. [CrossRef] [PubMed]

302. Mizobuchi, M.; Towler, D.; Slatopolsky, E. Vascular calcification: The killer of patients with chronic kidney disease. J. Am. Soc. Nephrol. 2009, 20, 1453-1464. [CrossRef]

303. Silswal, N.; Touchberry, C.D.; Daniel, D.R.; McCarthy, D.L.; Zhang, S.; Andresen, J.; Stubbs, J.R.; Wacker, M.J. Fgf23 directly impairs endothelium-dependent vasorelaxation by increasing superoxide levels and reducing nitric oxide bioavailability. Am. J. Physiol. Endocrinol. Metab. 2014, 307, E426-E436. [CrossRef]

304. Wohlfahrt, P.; Melenovsky, V.; Kotrc, M.; Benes, J.; Jabor, A.; Franekova, J.; Lemaire, S.; Kautzner, J.; Jarolim, P. Association of fibroblast growth factor-23 levels and angiotensin-converting enzyme inhibition in chronic systolic heart failure. JACC Heart Fail. 2015, 3, 829-839. [CrossRef]

305. David, V.; Francis, C.; Babitt, J.L. Ironing out the cross talk between fgf23 and inflammation. Am. J. Physiol. Ren. Physiol. 2017, 312, F1-F8. [CrossRef]

306. Desjardins, L.; Liabeuf, S.; Renard, C.; Lenglet, A.; Lemke, H.D.; Choukroun, G.; Drueke, T.B.; Massy, Z.A. Fgf23 is independently associated with vascular calcification but not bone mineral density in patients at various ckd stages. Osteoporos. Int. 2012, 23, 2017-2025. [CrossRef] 
307. Faul, C.; Amaral, A.P.; Oskouei, B.; Hu, M.C.; Sloan, A.; Isakova, T.; Gutierrez, O.M.; Aguillon-Prada, R.; Lincoln, J.; Hare, J.M.; et al. Fgf23 induces left ventricular hypertrophy. J. Clin. Investig. 2011, 121, 4393-4408. [CrossRef]

308. Stöhr, R.; Schuh, A.; Heine, G.H.; Brandenburg, V. Fgf23 in cardiovascular disease: Innocent bystander or active mediator? Front. Endocrinol. 2018, 9, 351. [CrossRef]

309. Bansal, N.; Zelnick, L.; Robinson-Cohen, C.; Hoofnagle, A.N.; Ix, J.H.; Lima, J.A.; Shoben, A.B.; Peralta, C.A.; Siscovick, D.S.; Kestenbaum, B.; et al. Serum parathyroid hormone and 25-hydroxyvitamin d concentrations and risk of incident heart failure: The multi-ethnic study of atherosclerosis. J. Am. Heart Assoc. 2014, 3, e001278. [CrossRef] [PubMed]

310. Lafferty, F.W. Primary hyperparathyroidism. Changing clinical spectrum, prevalence of hypertension, and discriminant analysis of laboratory tests. Arch. Intern. Med. 1981, 141, 1761-1766. [CrossRef] [PubMed]

311. Stefenelli, T.; Abela, C.; Frank, H.; Koller-Strametz, J.; Globits, S.; Bergler-Klein, J.; Niederle, B. Cardiac abnormalities in patients with primary hyperparathyroidism: Implications for follow-up. J. Clin. Endocrinol. Metab. 1997, 82, 106-112. [CrossRef]

312. Brown, S.J.; Ruppe, M.D.; Tabatabai, L.S. The parathyroid gland and heart disease. Methodist. Debakey Cardiovasc. J. 2017, 13, 49-54. [CrossRef] [PubMed]

313. Lau, W.L.; Pai, A.; Moe, S.M.; Giachelli, C.M. Direct effects of phosphate on vascular cell function. Advances Chronic Kidney Dis. 2011, 18, 105-112. [CrossRef]

314. Shanahan, C.M.; Crouthamel, M.H.; Kapustin, A.; Giachelli, C.M. Arterial calcification in chronic kidney disease: Key roles for calcium and phosphate. Circ. Res. 2011, 109, 697-711. [CrossRef]

315. Reynolds, J.L.; Joannides, A.J.; Skepper, J.N.; McNair, R.; Schurgers, L.J.; Proudfoot, D.; Jahnen-Dechent, W.; Weissberg, P.L.; Shanahan, C.M. Human vascular smooth muscle cells undergo vesicle-mediated calcification in response to changes in extracellular calcium and phosphate concentrations: A potential mechanism for accelerated vascular calcification in esrd. J. Am. Soc. Nephrol. 2004, 15, 2857. [CrossRef]

316. Son, B.-K.; Kozaki, K.; Iijima, K.; Eto, M.; Nakano, T.; Akishita, M.; Ouchi, Y. Gas6/axl-pi3k/akt pathway plays a central role in the effect of statins on inorganic phosphate-induced calcification of vascular smooth muscle cells. Eur. J. Pharmacol. 2007, 556, 1-8. [CrossRef]

317. Rangrez, A.Y.; M’Baya-Moutoula, E.; Metzinger-Le Meuth, V.; Henaut, L.; Djelouat, M.S.; Benchitrit, J.; Massy, Z.A.; Metzinger, L. Inorganic phosphate accelerates the migration of vascular smooth muscle cells: Evidence for the involvement of mir-223. PLoS ONE 2012, 7, e47807. [CrossRef]

318. Duan, P.; Bonewald, L.F. The role of the wnt/beta-catenin signaling pathway in formation and maintenance of bone and teeth. Int. J. Biochem. Cell Biol. 2016, 77, 23-29. [CrossRef] [PubMed]

319. Gaur, T.; Lengner, C.J.; Hovhannisyan, H.; Bhat, R.A.; Bodine, P.V.; Komm, B.S.; Javed, A.; van Wijnen, A.J.; Stein, J.L.; Stein, G.S.; et al. Canonical wnt signaling promotes osteogenesis by directly stimulating runx2 gene expression. J. Biol. Chem. 2005, 280, 33132-33140. [CrossRef] [PubMed]

320. Komori, T. Signaling networks in runx2-dependent bone development. J. Cell Biochem. 2011, 112, 750-755. [CrossRef] [PubMed]

321. Cai, T.; Sun, D.; Duan, Y.; Wen, P.; Dai, C.; Yang, J.; He, W. Wnt/beta-catenin signaling promotes vsmcs to osteogenic transdifferentiation and calcification through directly modulating runx2 gene expression. Exp. Cell Res. 2016, 345, 206-217. [CrossRef] [PubMed]

322. Deng, D.; Diao, Z.; Han, X.; Liu, W. Secreted frizzled-related protein 5 attenuates high phosphate-induced calcification in vascular smooth muscle cells by inhibiting the wnt/ss-catenin pathway. Calcif. Tissue Int. 2016, 99, 66-75. [CrossRef]

323. Anheim, M.; López-Sánchez, U.; Giovannini, D.; Richard, A.-C.; Touhami, J.; N'Guyen, L.; Rudolf, G.; Thibault-Stoll, A.; Frebourg, T.; Hannequin, D.; et al. Xpr1 mutations are a rare cause of primary familial brain calcification. J. Neurol. 2016, 263, 1559-1564. [CrossRef]

324. Villa-Bellosta, R.; Bogaert, Y.E.; Levi, M.; Sorribas, V. Characterization of phosphate transport in rat vascular smooth muscle cells. Arterioscler. Thromb. Vasc. Biol. 2007, 27, 1030-1036. [CrossRef]

325. Hortells, L.; Guillén, N.; Sosa, C.; Sorribas, V. Several phosphate transport processes are present in vascular smooth muscle cells. Am. J. Physiol. Heart Circ. Physiol. 2019, 318, H448-H460. [CrossRef]

326. Shuto, E.; Taketani, Y.; Tanaka, R.; Harada, N.; Isshiki, M.; Sato, M.; Nashiki, K.; Amo, K.; Yamamoto, H.; Higashi, Y.; et al. Dietary phosphorus acutely impairs endothelial function. J. Am. Soc. Nephrol. 2009, 20, 1504-1512. [CrossRef] 
327. Kendrick, J.; Ix, J.H.; Targher, G.; Smits, G.; Chonchol, M. Relation of serum phosphorus levels to ankle brachial pressure index (from the third national health and nutrition examination survey). Am. J. Cardiol. 2010, 106, 564-568. [CrossRef]

328. van Vuren, A.J.; Gaillard, C.A.J.M.; Eisenga, M.F.; van Wijk, R.; van Beers, E.J. The epo-fgf23 signaling pathway in erythroid progenitor cells: Opening a new area of research. Front. Physiol. 2019, 10, 304. [CrossRef] [PubMed]

329. Coe, L.M.; Madathil, S.V.; Casu, C.; Lanske, B.; Rivella, S.; Sitara, D. Fgf-23 is a negative regulator of prenatal and postnatal erythropoiesis. J. Biol. Chem. 2014, 289, 9795-9810. [CrossRef] [PubMed]

330. Clinkenbeard, E.L.; Hanudel, M.R.; Stayrook, K.R.; Appaiah, H.N.; Farrow, E.G.; Cass, T.A.; Summers, L.J.; Ip, C.S.; Hum, J.M.; Thomas, J.C.; et al. Erythropoietin stimulates murine and human fibroblast growth factor-23, revealing novel roles for bone and bone marrow. Haematologica 2017, 102, e427-e430. [CrossRef] [PubMed]

331. Brody, T.O.M. 4-regulation of energy metabolism. In Nutritional Biochemistry, 2nd ed.; Brody, T.O.M., Ed.; Academic Press: San Diego, CA, USA, 1999; pp. 157-271.

332. Smith, R.; Newman, R.J.; Radda, G.K.; Stokes, M.; Young, A. Hypophosphataemic osteomalacia and myopathy: Studies with nuclear magnetic resonance spectroscopy. Clin. Sci. 1984, 67, 505-509. [CrossRef] [PubMed]

333. Chande, S.; Caballero, D.; Ho, B.B.; Fetene, J.; Serna, J.; Pesta, D.; Nasiri, A.; Jurczak, M.; Chavkin, N.W.; Hernando, N.; et al. Slc20a1/pit1 and slc20a2/pit2 are essential for normal skeletal myofiber function and survival. Sci. Rep. 2020, 10, 3069. [CrossRef] [PubMed]

334. Lotz, M.; Ney, R.; Bartter, F.C. Osteomalacia and debility resulting from phosphorus depletion. Trans. Assoc. Am. Physicians 1964, 77, 281-295.

335. Chen, Y.-Y.; Kao, T.-W.; Chou, C.-W.; Wu, C.-J.; Yang, H.-F.; Lai, C.-H.; Wu, L.-W.; Chen, W.-L. Exploring the link between serum phosphate levels and low muscle strength, dynapenia, and sarcopenia. Sci. Rep. 2018, 8, 3573. [CrossRef]

336. Moore, L.W.; Nolte, J.V.; Gaber, A.O.; Suki, W.N. Association of dietary phosphate and serum phosphorus concentration by levels of kidney function. Am. J. Clin. Nutr. 2015, 102, 444-453. [CrossRef]

337. Zhang, Y.-Y.; Yang, M.; Bao, J.-F.; Gu, L.-J.; Yu, H.-L.; Yuan, W.-J. Phosphate stimulates myotube atrophy through autophagy activation: Evidence of hyperphosphatemia contributing to skeletal muscle wasting in chronic kidney disease. BMC Nephrol. 2018, 19, 45. [CrossRef]

338. Bose, S.; French, S.; Evans, F.J.; Joubert, F.; Balaban, R.S. Metabolic network control of oxidative phosphorylation: Multiple roles of inorganic phosphate. J. Biol. Chem. 2003, 278, 39155-39165. [CrossRef]

339. Phillips, D.; Aponte, A.M.; French, S.A.; Chess, D.J.; Balaban, R.S. Succinyl-coa synthetase is a phosphate target for the activation of mitochondrial metabolism. Biochemistry 2009, 48, 7140-7149. [CrossRef] [PubMed]

340. Rodriguez-Zavala, J.S.; Pardo, J.P.; Moreno-Sanchez, R. Modulation of 2-oxoglutarate dehydrogenase complex by inorganic phosphate, $\operatorname{Mg}(2+)$, and other effectors. Arch. Biochem. Biophys. 2000, 379, 78-84. [CrossRef] [PubMed]

341. Hansford, R.G. Some properties of pyruvate and 2-oxoglutarate oxidation by blowfly flight-muscle mitochondria. Biochem. J. 1972, 127, 271-283. [CrossRef] [PubMed]

342. Blonde, D.J.; Kresack, E.J.; Kosicki, G.W. The effects of ions and freeze-thawing on supernatant and mitochondrial malate dehydrogenase. Can. J. Biochem. 1967, 45, 641-650. [CrossRef] [PubMed]

343. Cook, W.J.; Senkovich, O.; Chattopadhyay, D. An unexpected phosphate binding site in glyceraldehyde 3-phosphate dehydrogenase: Crystal structures of apo, holo and ternary complex of cryptosporidium parvum enzyme. BMC Struct. Biol. 2009, 9, 9. [CrossRef]

344. Travis, S.F.; Sugerman, H.J.; Ruberg, R.L.; Dudrick, S.J.; Delivoria-Papadopoulos, M.; Miller, L.D.; Oski, F.A. Alterations of red-cell glycolytic intermediates and oxygen transport as a consequence of hypophosphatemia in patients receiving intravenous hyperalimentation. N. Engl. J. Med. 1971, 285, 763-768. [CrossRef]

345. Boyer, C.J.C.; Baines, A.D.; Beaulieu, É.; Béliveau, R. Immunodetection of a type iii sodium-dependent phosphate cotransporter in tissues and ok cells. Biochim. Biophys. Acta (BBA) Biomembr. 1998, 1368, 73-83. [CrossRef]

346. Werner, A.; Dehmelt, L.; Nalbant, P. $\mathrm{Na}^{+}$-dependent phosphate cotransporters: The napi protein families. J. Exp. Biol. 1998, 201, 3135-3142. 
347. Bai, L.; Collins, J.F.; Ghishan, F.K. Cloning and characterization of a type iii na-dependent phosphate cotransporter from mouse intestine. Am. J. Physiol. Cell Physiol. 2000, 279, C1135-C1143. [CrossRef]

348. Ravera, S.; Virkki, L.V.; Murer, H.; Forster, I.C. Deciphering pit transport kinetics and substrate specificity using electrophysiology and flux measurements. Am. J. Physiol. Cell Physiol. 2007, 293, C606-C620. [CrossRef]

349. Fiermonte, G.; Palmieri, L.; Dolce, V.; Lasorsa, F.M.; Palmieri, F.; Runswick, M.J.; Walker, J.E. The sequence, bacterial expression, and functional reconstitution of the rat mitochondrial dicarboxylate transporter cloned via distant homologs in yeast and caenorhabditis elegans. J. Biol. Chem. 1998, 273, 24754-24759. [CrossRef]

350. Fiermonte, G.; Dolce, V.; Arrigoni, R.; Runswick, M.J.; Walker, J.E.; Palmieri, F. Organization and sequence of the gene for the human mitochondrial dicarboxylate carrier: Evolution of the carrier family. Biochem. J. 1999, 344, 953-960. [CrossRef]

351. Mayr, J.A.; Merkel, O.; Kohlwein, S.D.; Gebhardt, B.R.; Böhles, H.; Fötschl, U.; Koch, J.; Jaksch, M.; Lochmüller, H.; Horváth, R.; et al. Mitochondrial phosphate-carrier deficiency: A novel disorder of oxidative phosphorylation. Am. J. Hum. Genet. 2007, 80, 478-484. [CrossRef]

352. Kwong, J.Q.; Davis, J.; Baines, C.P.; Sargent, M.A.; Karch, J.; Wang, X.; Huang, T.; Molkentin, J.D. Genetic deletion of the mitochondrial phosphate carrier desensitizes the mitochondrial permeability transition pore and causes cardiomyopathy. Cell Death Differ. 2014, 21, 1209-1217. [CrossRef] [PubMed]

353. Allen, D.G.; Trajanovska, S. The multiple roles of phosphate in muscle fatigue. Front. Physiol. 2012, 3, 463. [CrossRef] [PubMed]

354. Debold, E.P.; Romatowski, J.; Fitts, R.H. The depressive effect of pi on the force-pca relationship in skinned single muscle fibers is temperature dependent. Am. J. Physiol. Cell Physiol. 2006, 290, C1041-C1050. [CrossRef] [PubMed]

355. Fryer, M.W.; Owen, V.J.; Lamb, G.D.; Stephenson, D.G. Effects of creatine phosphate and P(i) on Ca ${ }^{2+}$ movements and tension development in rat skinned skeletal muscle fibres. J. Physiol. 1995, 482, 123-140. [CrossRef]

356. Lanza, I.R.; Wigmore, D.M.; Befroy, D.E.; Kent-Braun, J.A. In vivo atp production during free-flow and ischaemic muscle contractions in humans. J. Physiol. 2006, 577, 353-367. [CrossRef]

357. Jones, D.A.; Turner, D.L.; McIntyre, D.B.; Newham, D.J. Energy turnover in relation to slowing of contractile properties during fatiguing contractions of the human anterior tibialis muscle. J. Physiol. 2009, 587, 4329-4338. [CrossRef]

358. Seaberg, B.; Henslee, G.; Wang, S.; Paez-Colasante, X.; Landreth, G.E.; Rimer, M. Muscle-derived extracellular signal-regulated kinases 1 and 2 are required for the maintenance of adult myofibers and their neuromuscular junctions. Mol. Cell Biol. 2015, 35, 1238-1253. [CrossRef]

359. Wang, S.; Seaberg, B.; Paez-Colasante, X.; Rimer, M. Defective acetylcholine receptor subunit switch precedes atrophy of slow-twitch skeletal muscle fibers lacking erk1/2 kinases in soleus muscle. Sci. Rep. 2016, 6, 38745. [CrossRef] [PubMed]

360. Imel, E.A.; Econs, M.J. Approach to the hypophosphatemic patient. J. Clin. Endocrinol. Metab. 2012, 97, 696-706. [CrossRef] [PubMed]

361. Bergwitz, C. Dietary phosphate modifies lifespan in drosophila. Nephrol. Dial. Transpl. 2012, 27, 3399-3406. [CrossRef]

362. Rose, E.; Lee, D.; Xiao, E.; Zhao, W.; Wee, M.; Cohen, J.; Bergwitz, C. Endocrine regulation of mfs2 by branchless controls phosphate excretion and stone formation in drosophila renal tubules. Sci. Rep. 2019, 9, 8798. [CrossRef] [PubMed]

363. Yamada, S.; Tokumoto, M.; Tatsumoto, N.; Taniguchi, M.; Noguchi, H.; Nakano, T.; Masutani, K.; Ooboshi, H.; Tsuruya, K.; Kitazono, T. Phosphate overload directly induces systemic inflammation and malnutrition as well as vascular calcification in uremia. Am. J. Physiol. Ren. Physiol. 2014, 306, F1418-F1428. [CrossRef]

364. Ohnishi, M.; Razzaque, M.S. Dietary and genetic evidence for phosphate toxicity accelerating mammalian aging. FASEB J. 2010, 24, 3562-3571. [CrossRef]

365. Hong, S.-H.; Park, S.-J.; Lee, S.; Kim, S.; Cho, M.-H. Biological effects of inorganic phosphate: Potential signal of toxicity. J. Toxicol. Sci. 2015, 40, 55-69. [CrossRef]

366. Stenvinkel, P.; Heimbürger, O.; Paultre, F.; Diczfalusy, U.; Wang, T.; Berglund, L.; Jogestrand, T. Strong association between malnutrition, inflammation, and atherosclerosis in chronic renal failure. Kidney Int. 1999, 55, 1899-1911. [CrossRef] 
367. Stenvinkel, P.; Heimbürger, O.; Lindholm, B.; Kaysen, G.A.; Bergström, J. Are there two types of malnutrition in chronic renal failure? Evidence for relationships between malnutrition, inflammation and atherosclerosis (mia syndrome). Nephrol. Dial. Transpl. 2000, 15, 953-960. [CrossRef]

368. Wang, A.Y.; Woo, J.; Lam, C.W.; Wang, M.; Chan, I.H.; Gao, P.; Lui, S.F.; Li, P.K.; Sanderson, J.E. Associations of serum fetuin-a with malnutrition, inflammation, atherosclerosis and valvular calcification syndrome and outcome in peritoneal dialysis patients. Nephrol. Dial. Transpl. 2005, 20, 1676-1685. [CrossRef]

369. Jin, H.; Xu, C.-X.; Lim, H.-T.; Park, S.-J.; Shin, J.-Y.; Chung, Y.-S.; Park, S.-C.; Chang, S.-H.; Youn, H.-J.; Lee, K.-H.; et al. High Dietary Inorganic Phosphate Increases Lung Tumorigenesis and Alters Akt Signaling. Am. J. Respir. Crit. Care Med. 2008, 179, 59-68. [CrossRef] [PubMed]

370. Jiang, L.; Dai, Y.; Liu, X.; Wang, C.; Wang, A.; Chen, Z.; Heidbreder, C.E.; Kolokythas, A.; Zhou, X. Identification and experimental validation of $\mathrm{g}$ protein alpha inhibiting activity polypeptide 2 (gnai2) as a microrna-138 target in tongue squamous cell carcinoma. Hum. Genet. 2011, 129, 189-197. [CrossRef] [PubMed]

371. Lacerda-Abreu, M.A.; Russo-Abrahão, T.; Monteiro, R.Q.; Rumjanek, F.D.; Meyer-Fernandes, J.R. Inorganic phosphate transporters in cancer: Functions, molecular mechanisms and possible clinical applications. Biochim. Biophys. Acta (BBA) Bioenerg. 2018, 1870, 291-298. [CrossRef] [PubMed]

372. Hong, S.H.; Minai-Tehrani, A.; Chang, S.H.; Jiang, H.L.; Lee, S.; Lee, A.Y.; Seo, H.W.; Chae, C.; Beck, G.R., Jr.; Cho, M.H. Knockdown of the sodium-dependent phosphate co-transporter $2 \mathrm{~b}$ (npt2b) suppresses lung tumorigenesis. PLoS ONE 2013, 8, e77121. [CrossRef] [PubMed]

373. Bobko, A.A.; Eubank, T.D.; Driesschaert, B.; Dhimitruka, I.; Evans, J.; Mohammad, R.; Tchekneva, E.E.; Dikov, M.M.; Khramtsov, V.V. Interstitial inorganic phosphate as a tumor microenvironment marker for tumor progression. Sci. Rep. 2017, 7, 41233. [CrossRef]

374. Tran, T.; Bliuc, D.; Hansen, L.; Abrahamsen, B.; van den Bergh, J.; Eisman, J.A.; van Geel, T.; Geusens, P.; Vestergaard, P.; Nguyen, T.V.; et al. Persistence of excess mortality following individual nonhip fractures: A relative survival analysis. J. Clin. Endocrinol. Metab. 2018, 103, 3205-3214. [CrossRef]

(C) 2020 by the authors. Licensee MDPI, Basel, Switzerland. This article is an open access article distributed under the terms and conditions of the Creative Commons Attribution (CC BY) license (http://creativecommons.org/licenses/by/4.0/). 